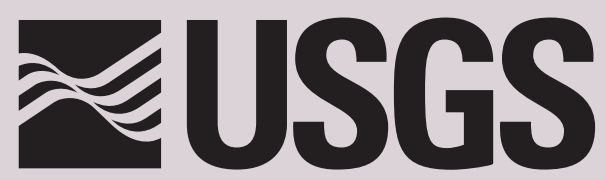

science for a changing world

\title{
Comparison of the Hydrogeology and Water Quality of a Ground-Water Augmented Lake with Two Non-Augmented Lakes in Northwest Hillsborough County, Florida
}

Water-Resources Investigations Report 02-4032

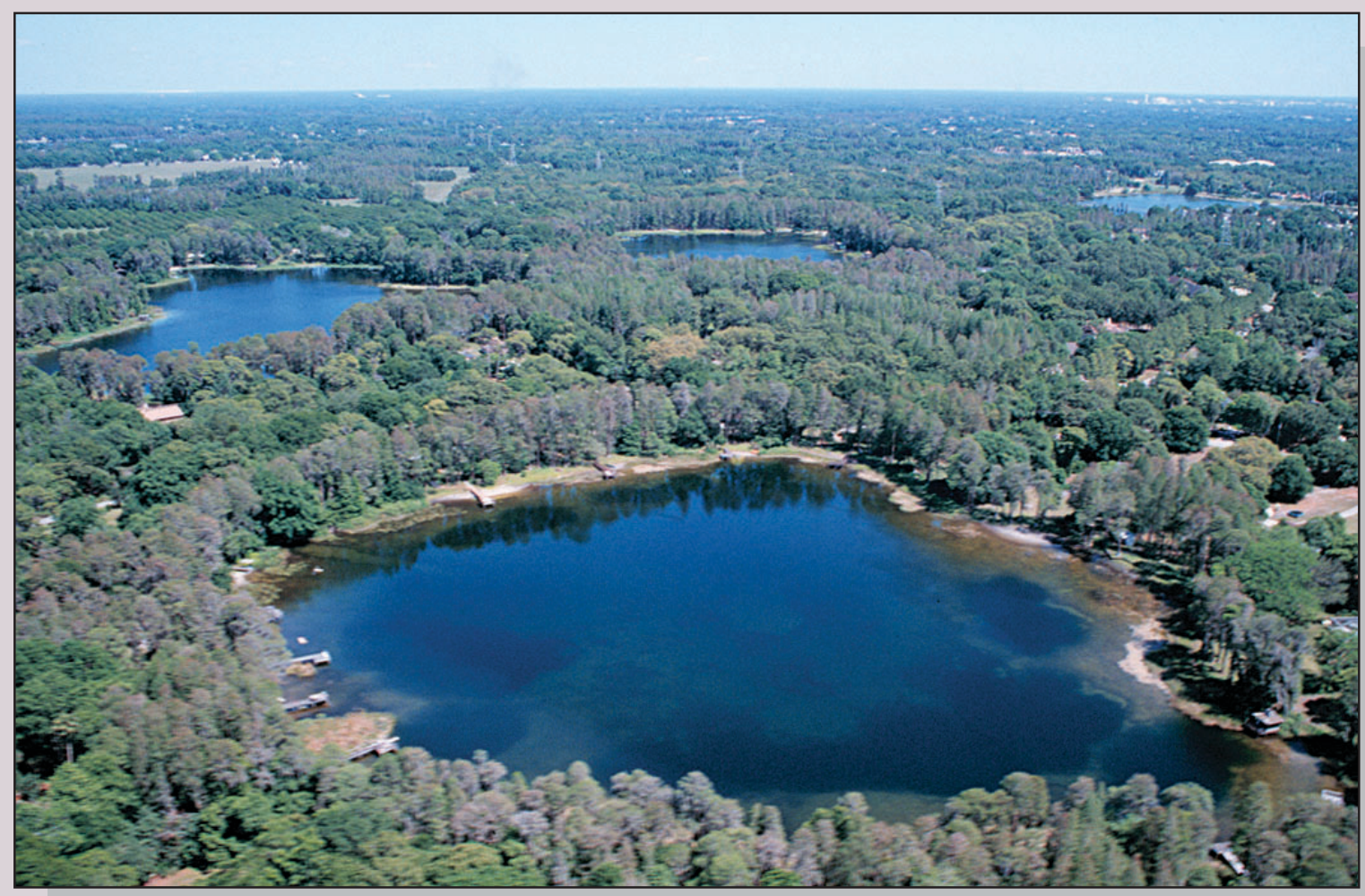

U.S. Department of the Interior

U.S. Geological Survey

Prepared in cooperation with the

Southwest Florida Water Management District 
Cover: Aerial photo of Round Lake from the western side; dark depressions in the lake bottom are dredged areas. Photo by: Richard Gant, Southwest Florida Water Management District 


\section{Comparison of the Hydrogeology and Water Quality of a Ground-Water Augmented Lake with Two Non-Augmented Lakes in Northwest Hillsborough County, Florida}

By P.A. Metz and Laura A. Sacks

U.S. Geological Survey

Water-Resources Investigations Report 02-4032

Prepared in cooperation with the

SOUTHWEST FLORIDA WATER MANAGEMENT DISTRICT

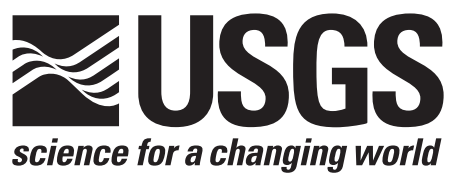




\section{U.S. DEPARTMENT OF THE INTERIOR \\ GALE A. NORTON, Secretary \\ U.S. GEOLOGICAL SURVEY \\ Charles G. Groat, Director}

Use of trade, product, or firm names in this publication is for descriptive purposes only and does not imply endorsement by the U.S. Geological Survey.

For additional information write to:

District Chief

U.S. Geological Survey

Suite 3015

227 N. Bronough Street

Tallahassee, FL 32301
Copies of this report can be purchased from:

U.S. Geological Survey
Branch of Information Services
Box 25286
Denver, CO $80225-0286$
888-ASK-USGS

Additional information about water resources in Florida is available on the internet at http://fl.water.usgs.gov 


\section{CONTENTS}

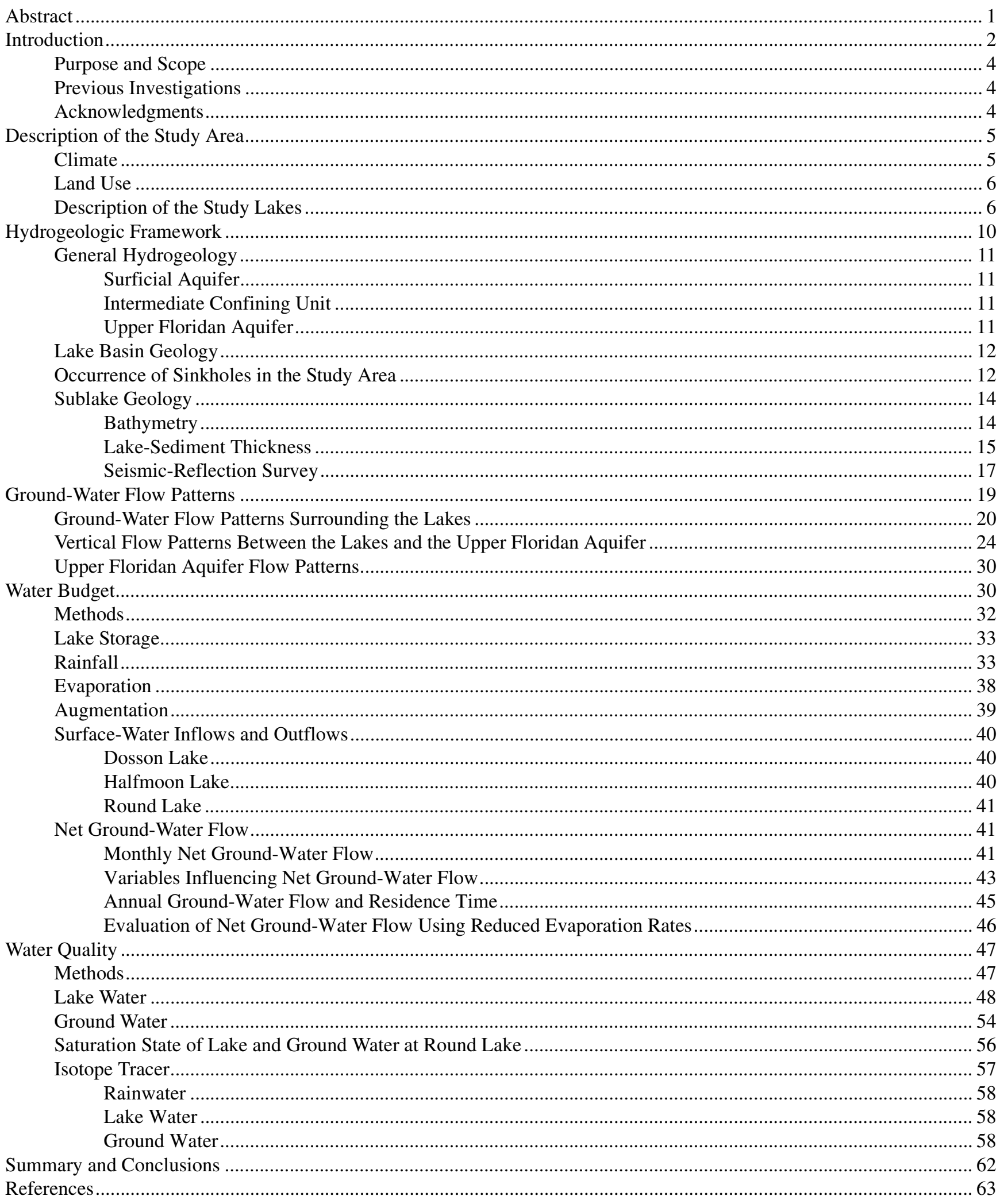


Appendixes

A. Well characteristics and data summary for wells in the study area...................................................................68

B. Median water quality for Dosson Lake, Halfmoon Lake, and Round Lake, October 1996 through June 1998 ............71

C. Range and median water quality for the surficial aquifer for each lake basin, October 1996 through June 1998 ........72

D. Water quality for the intermediate confining unit and Upper Floridan aquifer for each lake basin, October 1996

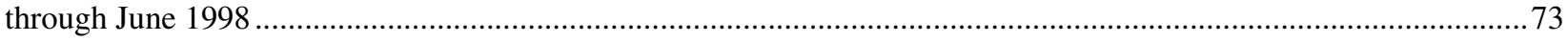

E. Isotopic data for rainfall samples at Section 21 well field ...................................................................................73

F. Isotopic data for water from the surficial aquifer, intermediate confining unit, and Upper Floridan aquifer for

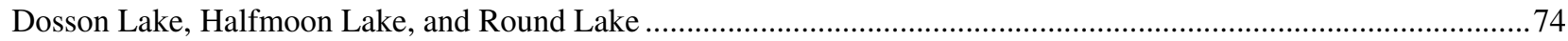

\section{FIGURES}

1. Map showing location of the study area, northwest Hillsborough County, Florida...................................................

2. Graph showing distribution of yearly rainfall and departure from average rainfall at Section 21 well field for water years 1979-99

3-5. Photographs showing land use and location of data-collection sites near:

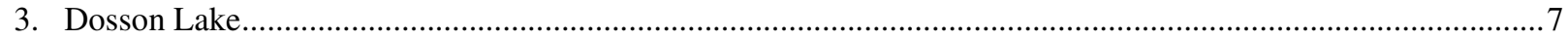

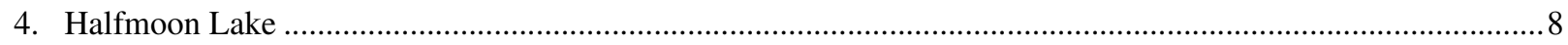

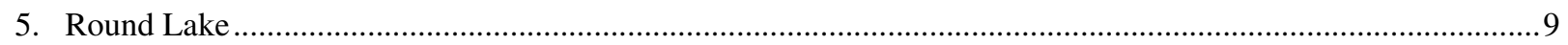

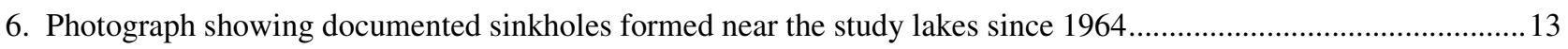

7-9. Maps showing bathymetry and soft sediment thickness for :

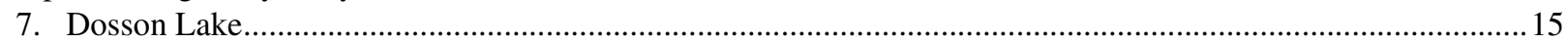

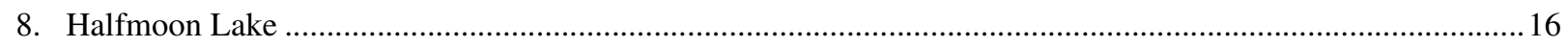

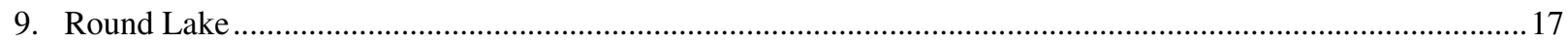

10-11. Graphs showing:

10. Seismic-reflection profile and interpretation of sublake geology for Dosson Lake, Halfmoon Lake, and Round Lake.

11. Three general ground-water flow patterns around lakes: ground-water flow-through, ground-water discharge, and ground-water recharge

12. Maps showing the interaction of ground water and lakes during a dry and wet period for Dosson Lake,

Halfmoon Lake, and Round Lake.....

13-15. Graphs showing:

13. Water levels in selected surficial aquifer wells and lake levels for Dosson Lake, Halfmoon Lake, and Round Lake.

14. Water levels in wells completed at different depths and lake levels for Dosson Lake, Halfmoon Lake, and Round Lake

15. Response of the water table and the Upper Floridan aquifer to rainfall .........................................................2 26

16-18. Hydrogeologic sections showing vertical head distribution for a low and high water-level condition along hydrogeologic section :

16. A-A' for Dosson Lake..

17. B-B' for Halfmoon Lake

18. C-C' for Round Lake

19. Maps showing the potentiometric surface of the Upper Floridan aquifer for high head condition (March 4, 1998) and low head condition (May 5, 1999)

20-26. Graphs showing:

20. Fluctuations of water levels within the Upper Floridan aquifer near Dosson Lake, Halfmoon Lake, and Round Lake

21. Lake hydrographs and stage-volume relation curves for Dosson Lake, Halfmoon Lake, and Round Lake .........37

22. Monthly rainfall at Section 21 well field climate station, June 1996 through May 1999..................................38

23. Monthly ground-water augmentation rates and monthly percentage of ground-water augmentation in relation to the lake volume for Round Lake, June 1996 through May 1999.

24. Seasonal variability of net ground-water flow for Dosson Lake, Halfmoon Lake, and Round Lake, June 1996 through May 1999 
25. Percentage of lake perimeter receiving ground-water inflow for Dosson Lake, Halfmoon Lake, and Round Lake

26. Comparison between net ground-water flow used in the water-budget analysis and net ground-water flow calculated with a 42 percent reduction in lake evaporation

27. Stiff diagrams for Dosson Lake, Halfmoon Lake, and Round Lake, and historical Stiff diagrams for

Round Lake

28-29. Graphs showing:

28. Comparison of field properties and selected chemical constituents for Dosson Lake, Halfmoon Lake, and

Round Lake, November 1996 through July 1998

29. Depth profiles of temperature, dissolved oxygen, specific conductance, and $\mathrm{pH}$ for Dosson Lake, Halfmoon Lake, and Round Lake, May 1996

30. Stiff diagrams for the lake water and ground water at Dosson Lake, Halfmoon Lake, and Round Lake, June 1998

31-34. Graphs showing:

31. Seasonal saturation index with respect to calcite for Round Lake, October 1996 through July 1998 56

32. Delta deuterium plotted against delta oxygen-18 for rainwater from Section 21 well field and lake water from Dosson Lake, Halfmoon Lake, and Round Lake, October 1997 through October 1998 58

33. Delta deuterium plotted against delta oxygen-18 for ground water and lake water at Dosson Lake, Halfmoon Lake, and Round Lake, October 1997 through October 1998

34. Delta oxygen-18 in water from well nests at Dosson Lake, Halfmoon Lake, and Round Lake, June 1998

\section{TABLES}

1. Hydrogeologic units, their equivalent stratigraphic units, and aquifer characteristics in northwest Hillsborough County

2. Average and maximum lateral inflow and outflow head gradient within the surficial aquifer at Dosson Lake, Halfmoon Lake, and Round Lake

3. Monthly water-budget terms, computed net ground-water flow, and estimated uncertainty or error associated with the computed net ground-water flow for Dosson Lake, June 1996 through May 1999

4. Monthly water-budget terms, computed net ground-water flow, and estimated uncertainty or error associated with the computed net ground-water flow for Halfmoon Lake, June 1996 through May 1999

5. Monthly water-budget terms, computed net ground-water flow, and estimated uncertainty or error associated with the computed net ground-water flow for Round Lake, June 1996 through May 1999.

6. Summary of relations between monthly net ground-water flow and selected hydraulic variables ............................... 43

7. Annual estimate of ground-water inflow and outflow for Dosson Lake, Halfmoon Lake, and Round Lake.....

8. Evaluation of annual net ground-water flow using a 42 percent reduction in lake evaporation for Dosson Lake, Halfmoon Lake, and Round Lake.

9. Saturation state of lake and ground-water samples with respect to calcite for the Round Lake basin ..

10. Percentage of lake leakage in the surrounding ground-water system at Round Lake based on delta oxygen-18 
CONVERSION FACTORS, VERTICAL DATUM, ACRONYMS, AND ABBREVIATIONS

\begin{tabular}{rll} 
Multiply & By & To obtain \\
inch (in.) & 2.54 & centimeter \\
foot $(\mathrm{ft})$ & 0.3048 & meter \\
mile $(\mathrm{mi})$ & 1.609 & kilometer \\
acre & 4,047 & square meter \\
acre & 0.4047 & hectare \\
foot squared $\left(\mathrm{ft}^{2}\right)$ & 0.09290 & square meter \\
inch per month $(\mathrm{in} / \mathrm{mo})$ & 2.54 & centimeter per month \\
inch per year $(\mathrm{in} / \mathrm{yr})$ & 2.54 & centimeter per year \\
inch per year $(\mathrm{in} / \mathrm{yr})$ & 2.54 & centimeter per year \\
foot per foot $(\mathrm{ft} / \mathrm{ft})$ & 1.00 & meter per meter \\
foot squared per day $\left(\mathrm{ft}^{2} / \mathrm{d}\right)$ & 0.09290 & meter squared per day \\
cubic foot $\left(\mathrm{ft}{ }^{3}\right)$ & 0.02832 & cubic meter \\
cubic foot per month $\left(\mathrm{ft}^{3} / \mathrm{mo}\right)$ & 0.02832 & cubic meter per month \\
cubic foot per second $\left(\mathrm{ft}^{3} / \mathrm{s}\right)$ & 0.02832 & cubic meter per second \\
foot per second $(\mathrm{ft} / \mathrm{s})$ & 0.3048 & meter per second \\
gallons per minute $(\mathrm{gal} / \mathrm{min})$ & 0.06308 & liters per second \\
million gallons per day $(\mathrm{Mgal} / \mathrm{d})$ & 0.04381 & cubic meter per second \\
\hline
\end{tabular}

Temperature in degrees Celsius $\left({ }^{\circ} \mathrm{C}\right)$ can be converted to degrees Fahrenheit $\left({ }^{\circ} \mathrm{F}\right)$ as follows: ${ }^{\circ} \mathrm{F}=\left(1.8 \mathrm{x}{ }^{\circ} \mathrm{C}\right)+32$

Temperature in degrees Fahrenheit $\left({ }^{\circ} \mathrm{F}\right)$ can be converted to degrees Celsius $\left({ }^{\circ} \mathrm{C}\right)$ as follows: ${ }^{\circ} \mathrm{C}=\left({ }^{\circ} \mathrm{F}-32\right) / 1.8$

Cubic foot $\left(\mathrm{ft}^{3}\right)$ can be converted to gallons as follows: 1 cubic foot $=7.48$ gallons

Sea level: In this report, "sea level" refers to the National Geodetic Vertical Datum of 1929 (NGVD of 1929) -- a geodetic datum derived from a general adjustment of the first-order level nets of the United States and Canada, formerly called Sea Level Datum of 1929.

$\begin{array}{rll}\text { GPS } & \text { global positioning system } \\ \mathrm{mg} / \mathrm{L} & \text { milligrams per liter } \\ \mathrm{r}^{2} & \text { coefficient of determination } \\ \text { SWFWMD } & \text { Southwest Florida Water Management District } \\ \mathrm{TSI} & \text { Tropic State Index } \\ \mathrm{USGS} & \text { U.S. Geological Survey } \\ \delta & \text { delta } \\ \delta^{18} \mathrm{O} & \text { delta oxygen-18 } \\ \delta \mathrm{D} & \text { delta deuterium } \\ \mu \mathrm{S} / \mathrm{cm} & \text { microsiemens per centimeter }\end{array}$




\title{
Comparison of the Hydrogeology and Water Quality of a Ground-Water Augmented Lake with Two Non-Augmented Lakes in Northwest Hillsborough County, Florida
}

\author{
By P.A. Metz and Laura A. Sacks
}

\begin{abstract}
The hydrologic effects associated with augmenting a lake with ground water from the Upper Floridan aquifer were examined in northwest Hillsborough County, Florida, from June 1996 through May 1999. The hydrogeology, ground-water flow patterns, water budgets, and water-quality characteristics were compared between a lake that has been augmented for more than 30 years (Round Lake) and two nearby nonaugmented lakes (Dosson Lake and Halfmoon Lake).
\end{abstract}

Compared to the other study lakes, Round Lake is in a more leakage-dominated hydrogeologic setting. The intermediate confining unit is thin or highly breached, which increases the potential for vertical ground-water flow. Round Lake has the least amount of soft, organic lake-bottom sediments and the lake bottom has been dredged deeper and more extensively than the other study lakes, which could allow more leakage from the lake bottom. The area around Round Lake has experienced more sinkhole activity than the other study lakes. During this study, three sinkholes developed around the perimeter of the lake, which may have further disrupted the intermediate confining unit.

Ground-water flow patterns around Round Lake were considerably different than the nonaugmented lakes. For most of the study, ground- water augmentation artificially raised the level of Round Lake to about 2 to 3 feet higher than the adjacent water table. As a result, lake water recharged the surficial aquifer around the entire lake perimeter, except during very wet periods when ground-water inflow occurred around part of the lake perimeter. The non-augmented lakes typically had areas of ground-water inflow and areas of lake leakage around their perimeter, and during wet periods, ground-water inflow occurred around the entire lake perimeter. Therefore, the area potentially contributing ground water to the non-augmented lakes is much larger than for augmented Round Lake. Vertical head loss within the surficial aquifer was greater at Round Lake than the other study lakes, which is additional evidence of the limited confinement at Round Lake.

A comparison of the water quality and lakebottom sediments at the three lakes indicate that Round Lake is strongly influenced by the addition of large quantities of calcium-bicarbonate enriched augmentation water. Round Lake had higher alkalinity, $\mathrm{pH}$, calcium and dissolved oxygen concentrations, specific conductance, and water clarity than the two non-augmented lakes. Round Lake was generally saturated to supersaturated with respect to calcite, but was undersaturated when augmentation was low and after high rainfall periods. 
Calcium carbonate has accumulated in the lake sediments from calcite precipitation, from macrophytes such as Nitella sp., and from the deposition of carbonate-rich mollusk shells, such as Planerbella sp., both of which thrive in the high alkalinity lake water. Lake-bottom sediments and aquatic biota at Round Lake had some of the highest radium-226 activity levels measured in a Florida lake. The high radium-226 levels (27 disintegrations per minute per dry mass) can be atrributed to augmenting the lake with ground water from the Upper Floridan aquifer. Although the ground water has relatively low levels of radium-226 (5.8 disintegrations per minute per liter), the large volumes of ground water added to the lake for more than 30 years have caused radium-226 to accumulate in the sediments and lake biota.

The Round Lake basin had higher calcium and bicarbonate concentrations in the surficial aquifer than at the non-augmented lakes, which indicates the lateral leakage of calcium-bicarbonate enriched lake water into the surficial aquifer. Deuterium and oxygen-18 data indicated that water in well nests near the lake consists of as much as 100 percent lake leakage, and water from the augmentation well had a high percentage of recirculated lake water (between 59 and 73 percent lake leakage). The ground water surrounding Round Lake was undersaturated with respect to calcite, indicating that the water is capable of dissolving calcite in the underlying limestone aquifer.

Annual and monthly ground-water outflow (lake leakage) was significantly higher at Round Lake than at the non-augmented lakes for the 3-year study period. Minimum estimates of the total annual ground-water inflow and outflow were made from monthly net ground-water flow values. Based on these estimates, total annual groundwater outflow from Round Lake was more than 10 times higher than for the non-augmented lakes. Local ground-water pumping, augmentation, and hydrogeologic factors are responsible for the high net ground-water outflow at Round Lake. Localized ground-water pumping causes the head difference between the lake and the Upper Floridan aquifer to increase, which increases lake leakage and results in lower lake levels. Augmenting the lake further increases the head difference between the lake, the water table, and the Upper Floridan aquifer, which results in an increase in lateral and vertical lake leakage. The lack of confinement or breaches in the intermediate confining unit facilitates the downward movement of this augmented lake water back into the Upper Floridan aquifer. The increase in ground-water circulation in the leakage-dominated hydrogeologic setting at Round Lake has made the basin more susceptible to karst activity (limestone dissolution, subsidence, and sinkhole formation).

\section{INTRODUCTION}

Many lakes in northwest Hillsborough County, Florida, have experienced water-level declines during the past several decades. These water-level declines have been directly linked to increases in ground-water use, low rainfall periods, and changes in surface-drainage patterns due to urban development (Stewart, 1968; Stewart and Hughes, 1974; Lopez and Fretwell, 1992; Southwest Florida Water Management District, 1996). Surface-water bodies in this area generally are well connected to the ground-water system and, as low rainfall periods continue and ground-water use increases, water-level declines can be observed in lakes and wetlands.

Water managers are considering restoring lakes in the northwest Hillsborough County area that are below acceptable water levels. Ground-water augmentation is a restoration method that uses ground water from the Upper Floridan aquifer to maintain water levels in lakes. As of 1999, 15 lakes in the northwest Hillsborough County area are being augmented with ground water and additional lakes are being considered for future augmentation (Southwest Florida Water Management District, written commun., 1999). As water demands increase in the northwest Hillsborough County area, many scientists, water managers, and citizens are uncertain about the widespread use of the ground-water resources to restore lake levels and the hydrologic, water-quality, and biological consequences of augmenting lakes with ground water. 
In 1995, the U.S. Geological Survey (USGS) began a cooperative study with the Southwest Florida Water Management District (SWFWMD) to gain a better understanding of the hydrogeologic and waterquality effects of augmenting lakes with ground water from the Upper Floridan aquifer. A thorough under- standing of the hydrogeology of augmented lakes is essential in developing effective water-management practices. This study compares an augmented lake (Round Lake) to two nearby non-augmented lakes (Dosson Lake and Halfmoon Lake). The location of the study area is shown in figure 1 .

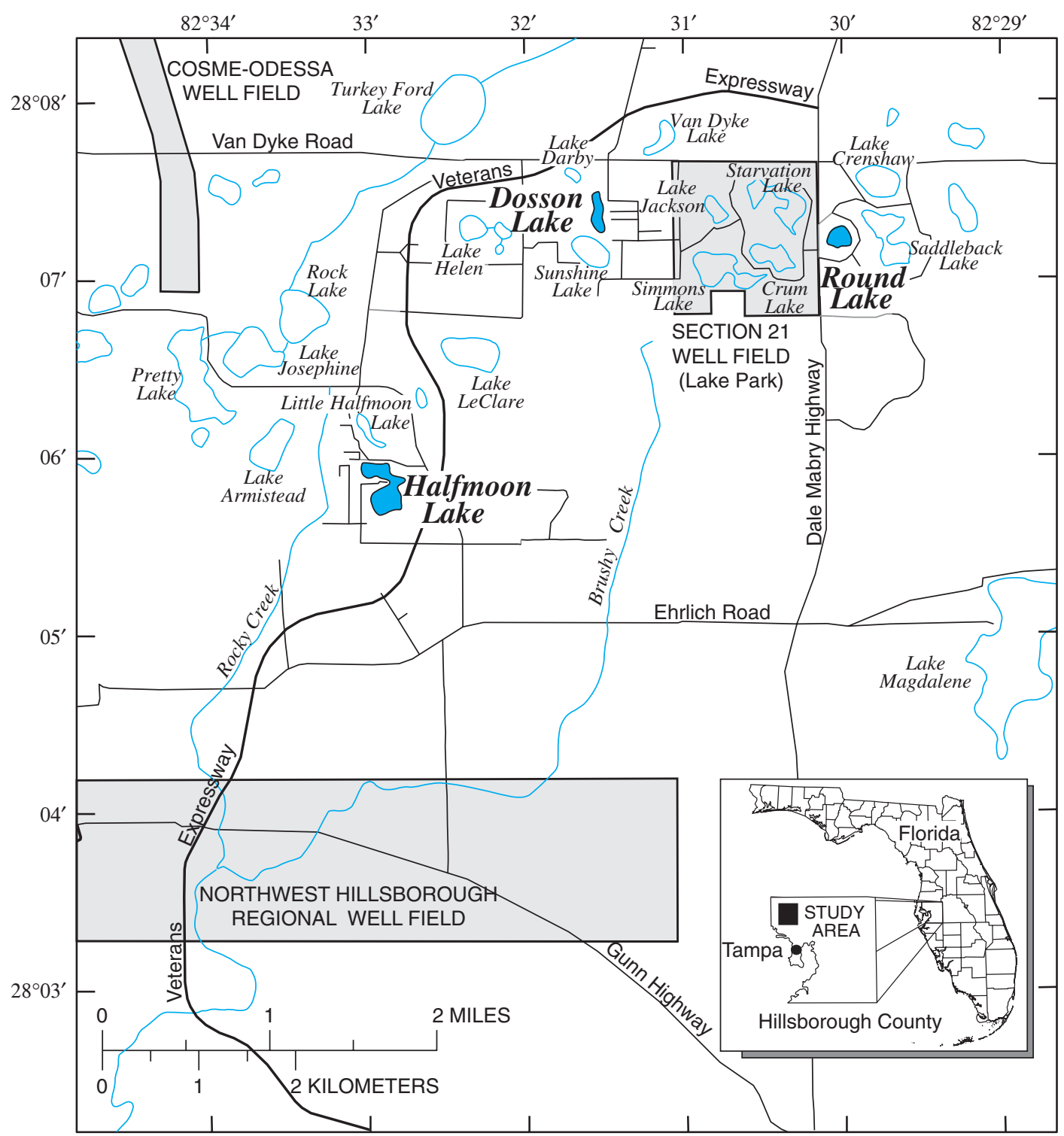

Base from U.S. Geological Survey digital data, 1 : 24,000, 1987

Albers Equal-Area Conic Projection

Standard Parallels $29^{\circ} 30^{\prime}$ and $45^{\circ} 30^{\prime}$, central meridian $-83^{\circ} 00^{\prime}$

\section{EXPLANATION}

STUDY LAKES

WELL-FIELD BOUNDARY

Figure 1. Location of the study area, northwest Hillsborough County, Florida. 


\section{Purpose and Scope}

The purpose of this report is to describe the hydrogeologic and water-quality effects of using water from the Upper Floridan aquifer to maintain lake levels. This report compares the hydrogeologic setting, ground-water flow patterns, water budgets, and water quality of an augmented lake to two nearby non-augmented lakes. The lakes selected for the study are in northwest Hillsborough County, Florida, and include (1) Round Lake, which has been augmented for more than 30 years and is near a major well field, (2) Dosson Lake, a non-augmented lake that is near the same major well field but is not as hydrologically stressed as Round Lake, and (3) Halfmoon Lake, which will be augmented at a future date.

The results presented in this report are based on hydrologic, lithologic, geophysical, and water-quality data collected from June 1996 through May 1999 at the three lake basins. Some preliminary ground-water flow model results for Halfmoon Lake and Round Lake are included in this report, but are not a major topic of this report.

\section{Previous Investigations}

Many investigations have contributed to the understanding of the hydrology, hydrogeology, and the effects of ground-water augmentation in northwest Hillsborough County and surrounding areas. Appraisals of the ground-water resources and general hydrology of the study area are included in reports by Menke and others (1961), Stewart (1968), and Cherry and others (1970). Sinclair (1974) described in detail the hydrogeologic characteristics of the surficial aquifer of northwest Hillsborough County. Sinclair (1977) determined that sinkholes, sinkhole lakes, and wetlands are an important means of recharge to the Upper Floridan aquifer in the study area. Sinclair and others (1985) and Sinclair and Stewart (1985) described the study area as susceptible to sinkhole development and noted that many lakes in this region are of sinkhole origin. Stewart and Parker (1992) suggested that recharge to the Upper Floridan aquifer occurs through many localized breaches within the intermediate confining unit.

Hydrologic investigations of ground-water augmentation by Stewart and Hughes (1974) concluded that lake leakage and evaporation increased and lake chemistry was altered because of ground-water augmentation at Round Lake. Martin and others (1976) determined that augmented lake water increased in hardness, magnesium, and inorganic carbon, which led to the growth of exotic submerged vegetation. Dooris and others (1982) concluded that inorganic carbon introduced by augmented waters influenced phytoplankton populations. Belanger and Kirkner (1994) determined that more than 90 percent of augmented surface-water returned to the ground-water system at Mountain Lake in Polk County. Allen (1999) concluded that augmentation at Round Lake did not reduce fish species richness but may hamper the abundance and size of important recreational sport fishes. Cowell (1999) reported that the augmentation of Round Lake with calcium-rich ground water may have contributed to the proliferation of mollusks. Brenner and Whitmore (1999) documented high levels of radium-226 within the lake sediments, and Brenner and others (2000) reported the accumulation of radium-226 in the biota of Round Lake.

\section{Acknowledgments}

The authors express their appreciation to the many private homeowners who permitted the installation of hydrologic instrumentation, drilling of shallow and deep wells, and sampling of wells for water quality. Acknowledgments are extended to the Florida Department of Transportation for granting permission to drill monitor wells on public land, the City of St. Petersburg for permitting the installation of an evaporation site at the Section 21 well field (Lake Park), and members of the Halfmoon Lake and Round Lake Associations, and Dosson and Dolores Marsh for making the hydrologic investigation of these private lakes possible. Special acknowledgments are due to Woody Dames and Jim McManus for providing historical information and field assistance at Round Lake, and Craig Hutchinson and Steve Suarez for providing historical information and field assistance at Halfmoon Lake.

The authors acknowledge USGS employees Terrie Lee, J.W. Grubbs, Eve Kuniansky, Keith Halford, Dann Yobbi, and Arturo Torres for their constructive review comments, which helped the data design and analysis and enhanced the clarity of the report. Special recognition is given to USGS employees Ann Tihansky for analyzing the lake seismic-reflection data, Terrie Lee for her unwavering guidance, and Dan Duerr for his thoughtful antidotes. The authors also express their appreciation for the technical support from Mike Hancock and Doug Leeper of the SWFWMD and 
Mark Brenner and Tom Whitmore from the University of Florida for the collection and analysis of the lakesediment data. Finally, the authors would like to express their gratitude for the proficient field support of Eric Swenson, Ken Stelman, Holly Barnette, and Samantha Andrews.

\section{DESCRIPTION OF THE STUDY AREA}

The three study lakes are located approximately 12 miles (mi) north of downtown Tampa, in northwest Hillsborough County, Florida (fig. 1). The study lakes are located within the Gulf Coastal Lowlands (White, 1970) in a region named Land-O-Lakes within the Tampa Plain (Brooks, 1981). The topographic setting is a relatively flat, sandy plain where elevations range from 40 feet (ft) above sea level on the western side to approximately $60 \mathrm{ft}$ above sea level on the eastern side. This flat, sandy plain has relatively poor surface drainage that typically flows south to southwest towards Tampa Bay, and contains many localized surface depressions called sinkholes. Sinkholes are prevalent throughout the study area and are in all stages of development, including ancient stable depressions and those formed recently. The ancient shallow surface depressions usually contain swamps or cypress domes, which are one of the most characteristic vegetative and geomorphic features of the study area. Deeper depressions, extending as much as 15 to $20 \mathrm{ft}$ below land surface, infill with water and form sinkhole lakes. Many sinkhole lakes are located within the study area and their shapes commonly indicate how they developed. The shapes of the lakes vary from circular and elongated to those having an irregular outline. Lakes with an irregular and elongated outline result when many small sinkholes coalescence (Sinclair and others, 1985). Two streams located within the study area are Brushy Creek, draining the central area and Rocky Creek draining the western area; both flow southward towards Tampa Bay.

\section{Climate}

Warm, wet summers and relatively mild, dry springs characterize the subtropical climate of the study area. Rainfall varies seasonally with more than half the annual rainfall typically occurring during June through September. Rainfall tends to be unevenly distributed throughout the area during the summer months because most summer rainfall in Florida is derived from localized, convective thunderstorms. Winter rainfall commonly is more evenly distributed because storms generally result from frontal-type air masses that move from north to south across the State.

Evaporation rates are high in Florida and are higher than most of the country (Farnworth and others, 1982). The high evaporation rates in this subtropical climate are primarily due to high solar radiation and water temperatures. Long-term estimates of annual shallow lake evaporation ranges from 48 to 59 inches in central Florida and can vary depending on climatic conditions (Farnsworth and others, 1982; Sacks and others, 1994; Lee and Swancar, 1997).

Long-term average rainfall (1965-99 and 1979-99) at Section 21 well field is approximately 49 inches per year (in/yr). Yearly rainfall for the 1979-99 water years (October 1, 1978, through September 30, 1999) is shown in figure $2 \mathrm{a}$ and departure of annual rainfall
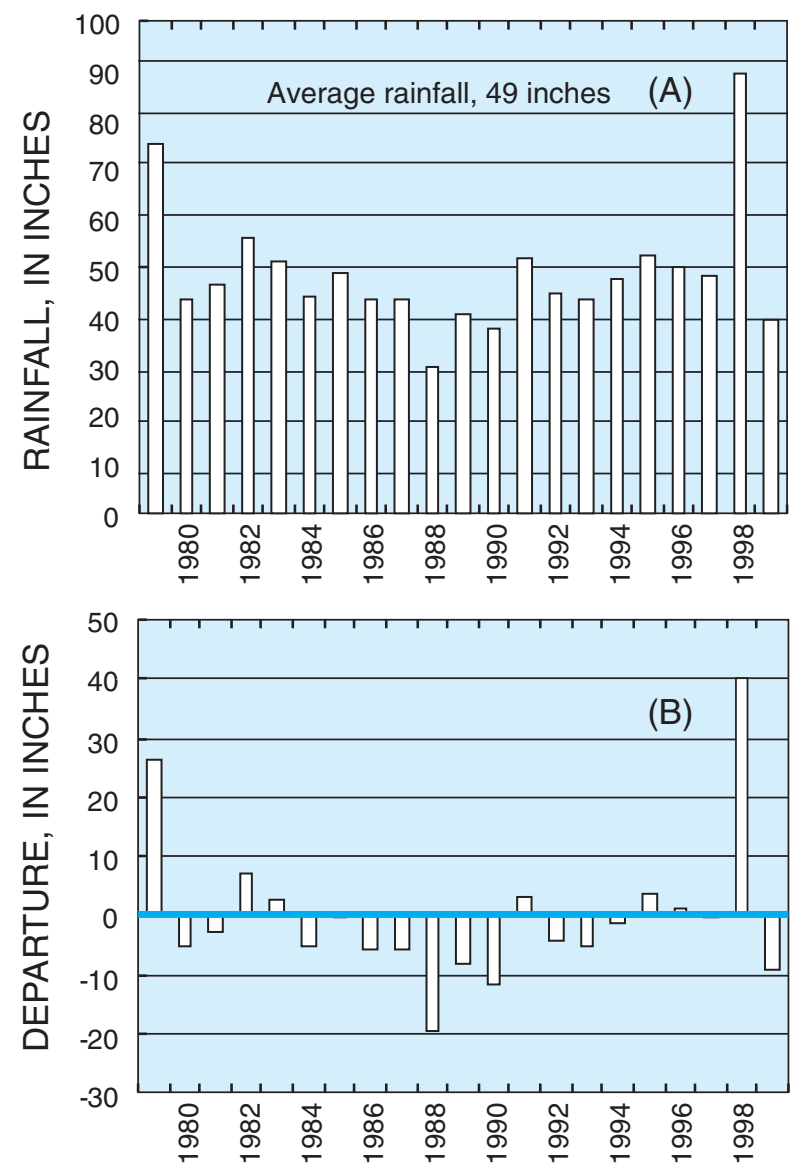

Figure 2. Distribution of yearly rainfall $(A)$ and departure from average rainfall $(B)$ at Section 21 well field for water years 1979-99. 
from the 21-year average at Section 21 well field is shown in figure $2 b$. During this period, 14 years had average to below average rainfall and 7 years had above average rainfall. Rainfall for 1979 had an excess of 26 in. above the average rainfall. From 1980-97, there was a long, dry period interspersed with an occasional year with average to above average rainfall.

For the 1998 water year, a tropical weather phenomenon called El Niño produced record rainfall throughout the study area. The El Niño weather pattern is characterized by unusually warm ocean temperatures in the Equatorial Pacific that change global weather patterns (Philander, 1990). As the result of El Niño conditions, a number of large frontal systems moved east across the Gulf of Mexico producing above average rainfall during October 1997 through March 1998. This rainfall contributed to approximately $40 \mathrm{in}$. above the average annual rainfall during the 1998 water year.

Climatic conditions changed again during the 1999 water year with the onset of a weather pattern called La Niña. La Niña is characterized by cooler than normal sea-surface temperatures in the central and eastern tropical Pacific Ocean that also change global weather patterns (Philander, 1990). Drier than normal conditions typically occur in the southeastern United States during a La Niña year. As a result of this weather patterns, rainfall for the 1999 water year was below average.

\section{Land Use}

Land use in the study area is predominately residential with numerous retail and small business centers. Industrial and agricultural land use is limited, and several recreational parks and golf courses are scattered throughout the study area. Three well fields exist in the study area: Section 21, Northwest Hillsborough Regional, and Cosme-Odessa (fig. 1). These well fields provide public, domestic, and industrial water supply from the Upper Floridan aquifer to the study area and to neighboring Pinellas County. Large pipelines are used to transport this ground water from the well fields to the surrounding areas.

Many lakes exist within the study area and lake front property is highly desirable as homesites. Most of the lakes in the study area have clusters of homes along the shoreline. Homes along these lakes typically have domestic supply wells and are on septic systems.

\section{Description of the Study Lakes}

Dosson Lake is a privately owned, 11-acre lake that is located approximately half a mile due west of Section 21 well field (fig. 3). The topography surrounding Dosson Lake is relatively flat and has an estimated surface drainage area (topographic basin) of 140 acres, of which approximately 33 percent is low-lying, undeveloped wetlands. To the north and south of Dosson Lake are wetland areas that consist of cypress domes with an understory of riparian ferns. Located in the wetlands to the north of Dosson Lake is Lake Darby, and to the south is Sunshine Lake. A hand-dug drainage ditch is located to the south of Dosson Lake, which connects with Sunshine Lake (fig. 3). The remaining land use surrounding Dosson Lake consists of residential homes on the eastern side, and mainly pastureland for cattle on the western side. The Dosson Lake topographic basin is the least developed of the three study lakes.

Halfmoon Lake is a privately owned, 33-acre lake that is located within an approximate 2-mi radius of Section 21, Cosme-Odessa, and Northwest Hillsborough Regional well fields (fig. 1). Little Halfmoon Lake is located to the north and Rocky Creek is located to the west of Halfmoon Lake (fig. 4). The topography surrounding Halfmoon Lake is slightly elevated on the eastern side and slopes gently downward towards Rocky Creek on the western side and has an estimated surface drainage area of 131 acres. Land use within the Halfmoon Lake basin is mostly residential, with a 25acre citrus grove situated on the southeastern side of the lake. Several small cypress-dominated wetlands are located in the southern ( 4 acres) and northeastern (3 acres) sides of the basin. The northwestern side of the lake has an overflow weir structure that controls lake levels during high rainfall (fig. 4).

Round Lake is a small, privately-owned lake that is located approximately $500 \mathrm{ft}$ east of the Section 21 well field (fig. 5). The 11-acre lake is bounded by Saddleback and Crenshaw Lakes to the east and Starvation and Crum Lakes to the west. The 30-acre topographic basin for Round Lake is the smallest of the three study lakes. Land use in this small drainage basin is residental with many homes outlining the small circular lake. Round Lake has no surface water outlet. An inflow drainage ditch exists on the northeastern side of the lake that connects with Saddleback Lake, although the lake level of Saddleback Lake is seldom high enough for it to overflow into this ditch (fig. 5). 


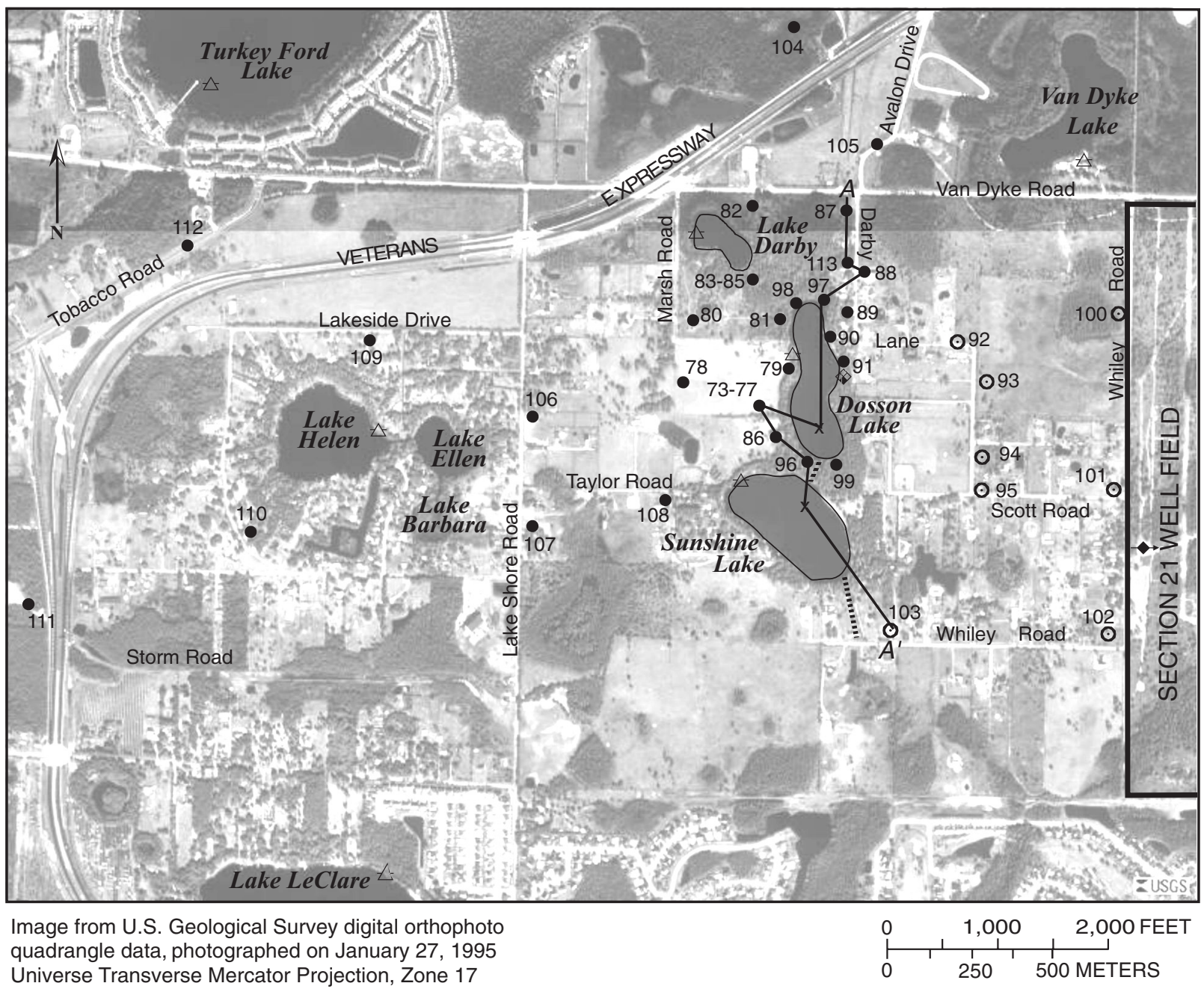

Universe Transverse Mercator Projection, Zone 17

\section{EXPLANATION}

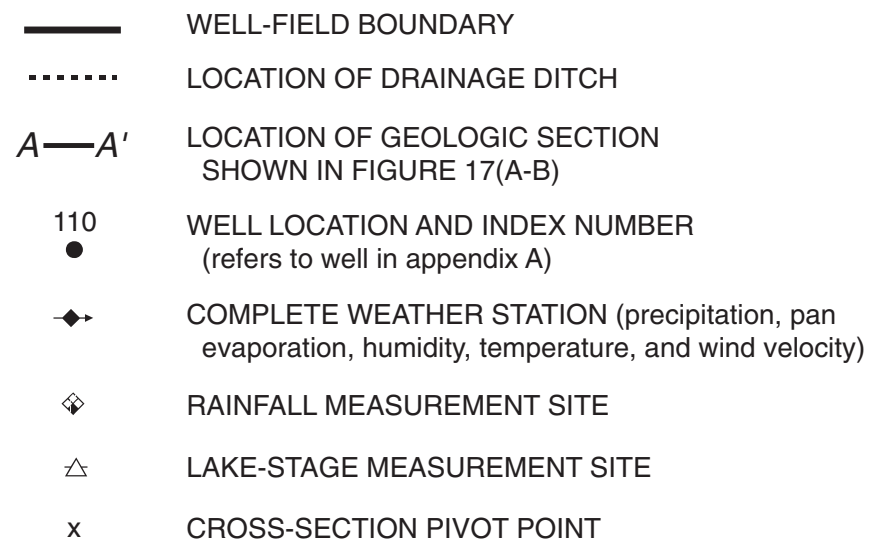

Figure 3. Land use and location of data-collection sites near Dosson Lake. 


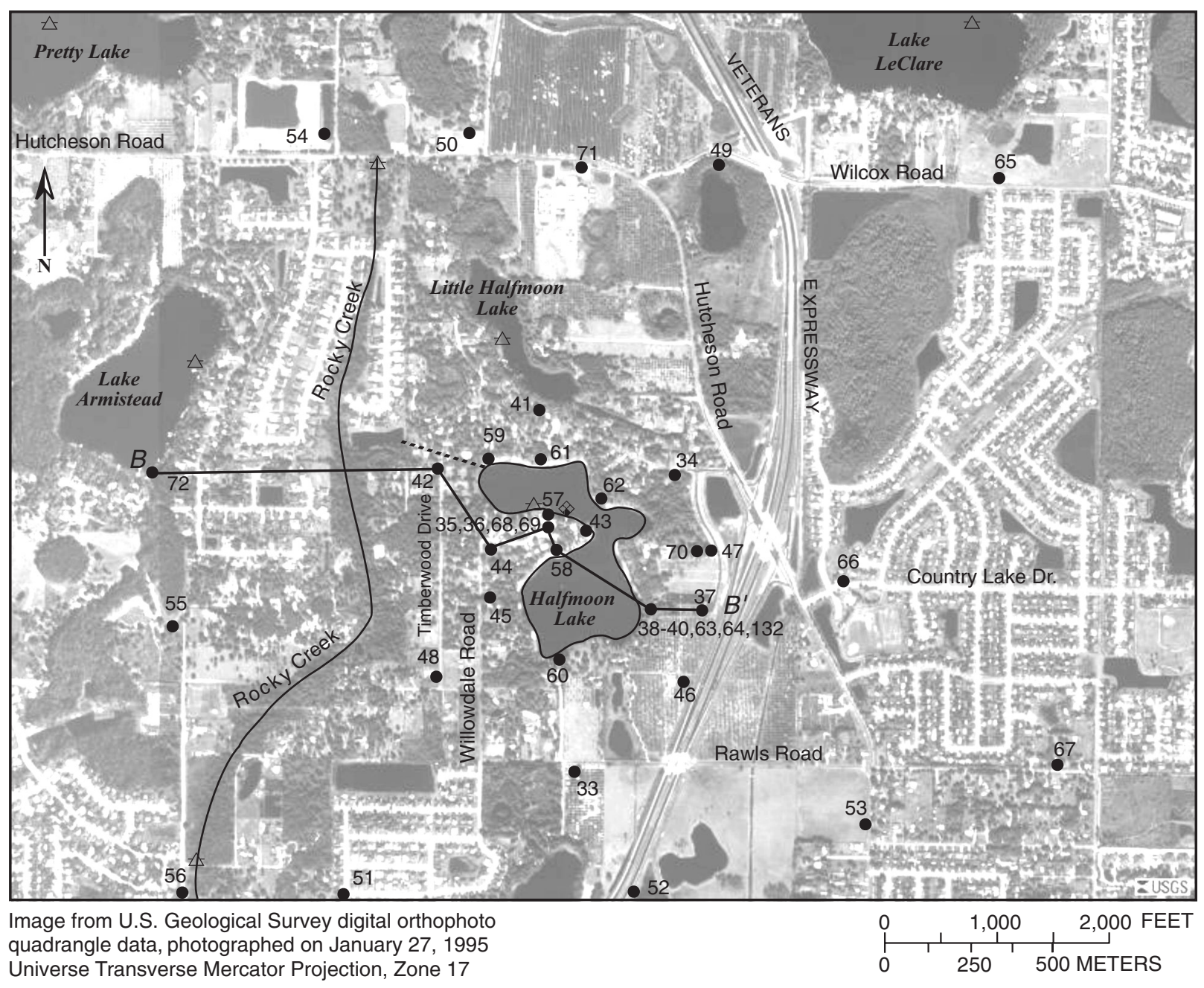

\section{EXPLANATION}

$\begin{array}{cl}B-B^{\prime} & \begin{array}{c}\text { LOCATION OF GEOLOGIC SECTION } \\ \text { SHOWN IN FIGURE 17 (A-B) }\end{array} \\ & \begin{array}{c}\text { LOCATION OF OVERFLOW WEIR } \\ \text { STRUCTURE }\end{array} \\ 55 & \begin{array}{c}\text { WELL LOCATION AND INDEX NUMBER } \\ \text { (refers to well in appendix A) }\end{array} \\ & \text { RAINFALL MEASUREMENT SITE } \\ & \text { LAKE-STAGE OR CREEK MEASUREMENT SITE }\end{array}$

Figure 4. Land use and location of data-collection sites near Halfmoon Lake. 


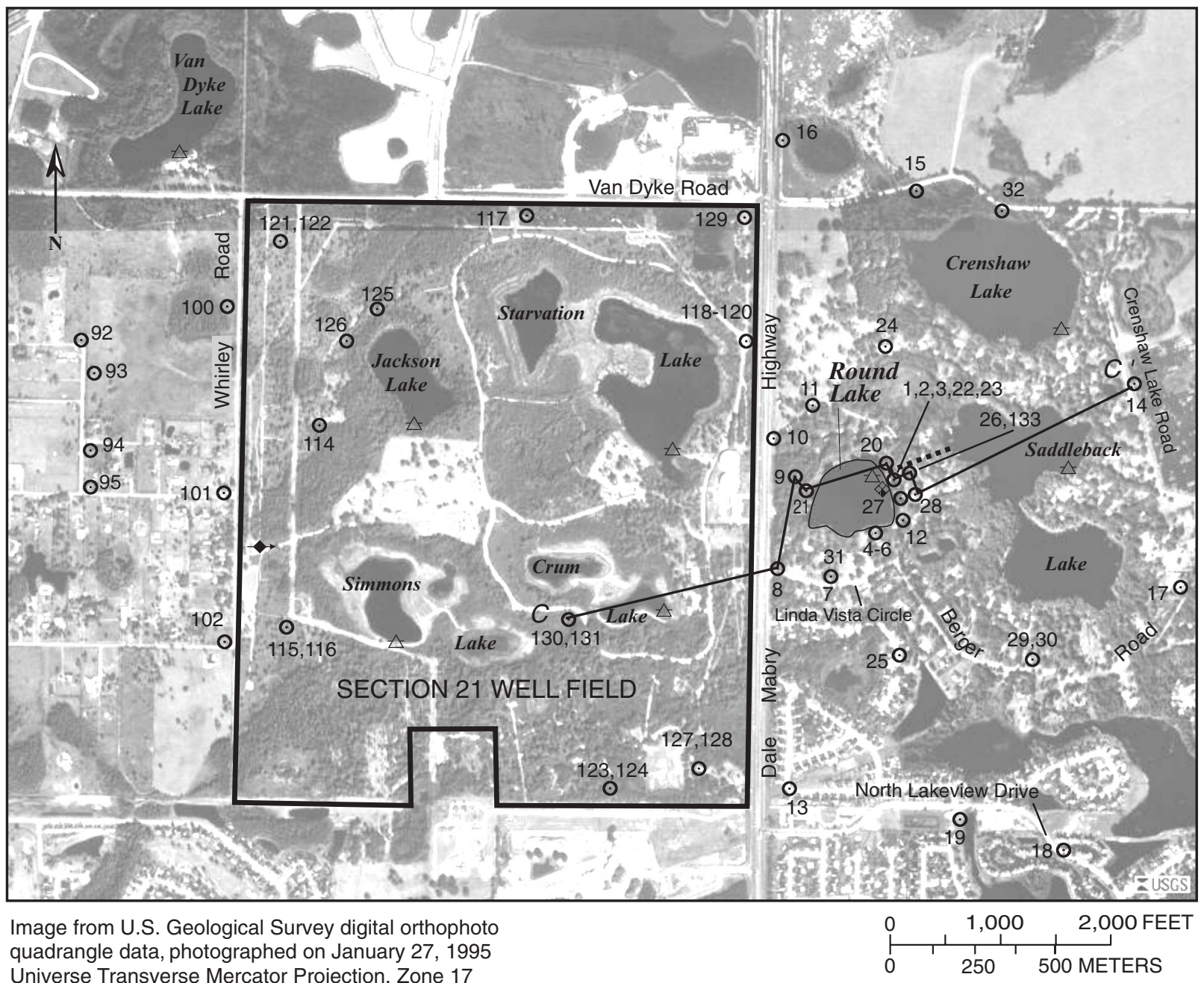

Universe Transverse Mercator Projection, Zone 17

\section{EXPLANATION}

WELL-FIELD BOUNDARY
LOCATION OF INFLOW DRAINAGE DITCH
\[ \begin{array}{l}\text { LOCATION OF GEOLOGIC SECTION } \\ \text { SHOWN IN FIGURE 18 (A-B) }\end{array} \]
$\begin{aligned} & \text { WELL LOCATION AND INDEX NUMBER } \\ & \text { (refers to well in appendix A) }\end{aligned}$
$\begin{aligned} & \text { COMPLETE WEATHER STATION-- Precipitation, } \\ & \text { pan evaporation, humidity, temperature, and wind velocity }\end{aligned}$
RAINFALL MEASUREMENT SITE
LAKE-STAGE MEASUREMENT SITE

Figure 5. Land use and location of data-collection sites near Round Lake. 
A decline in lake levels of 2 to $3 \mathrm{ft}$ in 1965 caused a drastic change in the aesthetic quality of Round Lake (Stewart and Hughes, 1974). Stewart (1968) and Stewart and Hughes (1974) describe in detail the hydrologic factors responsible for lake-level declines at Round Lake. These factors include well-field pumping, low rainfall conditions, and changes in the natural drainage patterns during urban development of northwest Hillsborough County. To restore lake levels, ground water from the Upper Floridan aquifer was pumped into Round Lake from one of the wells in the Section 21 well field during the summer of 1965 . This augmentation, however, ceased at the end of the summer and lake levels once again declined. Consequently, the Round Lake residents constructed an augmentation well of their own in June 1966, and since this time the lake has been augmented with ground water to a nearly constant level of $53 \mathrm{ft}$ above sea level. The well is located $170 \mathrm{ft}$ from the northeastern edge of the lake and ground water is pumped into a 15 -in. diameter corrugated pipe that slopes slightly downward to the lake.

\section{HYDROGEOLOGIC FRAMEWORK}

The geologic units underlying the study area consist of sand, clay, and carbonate rocks that were deposited primarily in a marine environment. Deposition of each formation was followed by a period of erosion that resulted in the development of solution cavities and surface irregularities. Principal hydrogeologic units of the study area include the surficial aquifer, the intermediate confining unit, and the Upper Floridan aquifer. The stratigraphic units associated with the hydrogeologic units include the undifferentiated surficial deposits, undifferentiated deposits of the Hawthorn Group, Tampa Member of the Arcadia Formation of the Hawthorn Group, and Suwannee Limestone. The hydrogeologic units, equivalent stratigraphic units, and a brief lithologic description of the units that hydraulically interact with the lakes are presented in table 1.

Table 1. Hydrogeologic units, their equivalent stratigraphic units, and aquifer characteristics in northwest Hillsborough County [Modified from Stewart, 1968, Sinclair, 1974, Miller, 1986, and Green and others, 1995]

\begin{tabular}{|c|c|c|c|c|c|}
\hline Age & $\begin{array}{l}\text { Stratigraphic } \\
\text { unit }\end{array}$ & $\begin{array}{c}\text { Hydrogeologic } \\
\text { unit }\end{array}$ & $\begin{array}{l}\text { Lithologic } \\
\text { description }\end{array}$ & $\begin{array}{l}\text { Range in } \\
\text { thickness } \\
\text { (feet) }\end{array}$ & $\begin{array}{c}\text { Aquifer } \\
\text { characteristics }\end{array}$ \\
\hline $\begin{array}{l}\text { Holocene } \\
\text { to } \\
\text { Pliocene }\end{array}$ & $\begin{array}{l}\text { Undifferentiated } \\
\text { surficial deposits }\end{array}$ & Surficial aquifer & $\begin{array}{l}\text { The surficial deposits consist } \\
\text { of an upper fine sand unit, } \\
\text { a sequence of clayey sand, } \\
\text { and a lower sequence } \\
\text { of sandy clay }\end{array}$ & 35 to 50 & $\begin{array}{l}\text { Limited use; lawn irrigation; } \\
\text { yields less than } 5 \text { gallons per } \\
\text { minute; high iron content }\end{array}$ \\
\hline \multirow[t]{2}{*}{ Miocene } & $\begin{array}{l}\text { Undifferentiated } \\
\text { deposits of the } \\
\text { Hawthorn Group }\end{array}$ & $\begin{array}{l}\text { Intermediate } \\
\text { confining unit }\end{array}$ & $\begin{array}{l}\text { Dense, plastic green-gray } \\
\text { clay, contains varying } \\
\text { amounts of sand, chert, and } \\
\text { phosphate; residual } \\
\text { limestone; clay } \\
\text { is variable in extent } \\
\text { and thickness }\end{array}$ & 0 to 20 & $\begin{array}{l}\text { Semiconfining unit retards } \\
\text { downward flow from the surficial } \\
\text { aquifer; breaches in clay unit } \\
\text { preferentially transmit recharge } \\
\text { to the Upper Floridan aquifer }\end{array}$ \\
\hline & $\begin{array}{l}\text { Tampa Member } \\
\text { of the Arcadia } \\
\text { Formation of the } \\
\text { Hawthorn Group }\end{array}$ & \multirow{2}{*}{$\begin{array}{l}\text { Upper Floridan } \\
\text { aquifer }\end{array}$} & $\begin{array}{l}\text { Highly weathered limestone } \\
\text { surface; white to light tan, } \\
\text { soft, moderately sandy and } \\
\text { clayey, fossiliferous }\end{array}$ & 20 to 240 & $\begin{array}{l}\text { Many domestic and public-supply } \\
\text { wells tap this unit; poor to fair } \\
\text { producer of water; yields from } \\
\text { a few to several hundred } \\
\text { gallons per minute }\end{array}$ \\
\hline Oligocene & $\begin{array}{l}\text { Suwannee } \\
\text { Limestone }\end{array}$ & & $\begin{array}{l}\text { Soft to hard limestone, } \\
\text { vuggy, granular, fossiliferous, } \\
\text { white to tan }\end{array}$ & 200 to 350 & $\begin{array}{l}\text { Domestic and large capacity } \\
\text { public-supply wells tap this unit; } \\
\text { yields from several hundred to } \\
\text { several thousand gallons } \\
\text { per minute }\end{array}$ \\
\hline
\end{tabular}




\section{General Hydrogeology}

The uppermost unit, the surficial aquifer, is an unconfined sand and clayey sand aquifer. The surficial aquifer is separated from the Upper Floridan aquifer by the clay-rich intermediate confining unit, which controls the downward recharge to the underlying aquifer. The lowermost unit, the Upper Floridan aquifer, is a highly productive carbonate aquifer and is the principal source of freshwater in west-central Florida (Miller, 1986).

\section{Surficial Aquifer}

The surficial aquifer is a permeable hydrogeologic unit contiguous with land surface, and principally consists of unconsolidated to poorly indurated clastic deposits (Southeastern Geological Society, 1986). Commonly, this unit is termed the surficial aquifer system where more than one permeable zone is present or where the deposits are interbedded. In this report, the deposits are considered to form a single homogeneous aquifer, and are referred to as the surficial aquifer.

The surficial aquifer contains a water table that is at a relatively shallow depth below land surface within the study area (approximately 0.5 to $10 \mathrm{ft}$ ). The surficial aquifer is recharged by rainfall that infiltrates the permeable deposits and percolates downward to the water table. Recharge to the water table is rapid because the surficial sands are generally permeable throughout the study area and the water table is close to land surface. The surficial aquifer has a large storage capacity and provides recharge to the underlying Upper Floridan aquifer. The surficial aquifer is not used as a significant source of water supply because of the relatively low yields to wells (less than 5 gallons per minute) (gal/min), high iron content, and the potential for contamination.

\section{Intermediate Confining Unit}

The intermediate confining unit is a nonwateryielding strata within the study area that consists of the undifferentiated deposits of the Hawthorn Group (Southeastern Geological Society, 1986). The unit consists of dense, marine green-gray plastic clay that contains varying amounts of sand, chert, phosphate, organic material, and carbonate mud (Sinclair, 1974). Elevated concentations of potassium, radium, and radionuclides commonly associated with clay minerals are also present in the intermediate confining unit
(Carr and Alverson, 1959). The clay unit is variable in extent and thickness throughout the study area; Sinclair (1974) reported clay in 47 of 59 test holes that was as much as $20 \mathrm{ft}$ thick and averaged about $4 \mathrm{ft}$. Carr and Alverson (1959) and Sinclair (1974) describe the clay in the intermediate confining unit as a weathered residuum of the limestone in the underlying Tampa Member.

Generally, ground water moves laterally in the surficial aquifer and then moves downward to the Upper Floridan aquifer through localized breaches in the intermediate confining unit. Stewart and Parker (1992) suggest that these breaches are actually sand columns that were created by localized subsidence activity. Sand columns are formed as overlying sand moves downward through collapsed clay and into limestone cavities. The sand columns are generally several feet or less in diameter and channel most of the localized recharge from the surficial aquifer to the Upper Floridan aquifer (Stewart and Parker, 1992). The rate of recharge is dependent on the size, frequency, and hydraulic conductivity of the sand columns (Stewart and Parker, 1992). The same geologic process also occurs under lakes where the limestone collapses and sand columns infiltrate or pipe into the cavities. These sand columns appear as small circular depressions in the lake bathymetry (Sinclair and others, 1985) and may increase the potential for leakage beneath lakes. Soft organic lake bottom sediments may impede leakage, but where these organic sediments are absent and the underlying clay layer is substantially disrupted, the potential for outflow beneath the lake may be enhanced.

\section{Upper Floridan Aquifer}

The Upper Floridan aquifer is the major source of water supply within the study area. This aquifer consists of limestone and dolomite, which contains many solution-enlarged fractures that commonly yield large supplies of water to wells. Transmissivities determined from aquifer tests of the Upper Floridan aquifer vary throughout the study area and range from 20,000 to 70,000 feet squared per day $\left(\mathrm{ft}^{2} / \mathrm{d}\right.$ ) (Wolansky and Corral, 1985; Southwest Florida Water Management District, 1994; and Langevin and others, 1998). This range is characteristic of fractured-rock aquifers and could be due to variations in the number and size of fractures intercepted by the test well or variations in the extent of aquifer penetration by the well. Water-bearing units of interest to the study are the Tampa Member of the Hawthorn Group and the Suwannee Limestone (table 1). 
The Tampa Member corresponds to the top of the Upper Floridan aquifer in the study area and ranges from 20 to $240 \mathrm{ft}$ thick (Stewart, 1968). Geologic logs describe the limestone of the Tampa Member as tan to white, usually sandy, fossiliferous, highly weathered in places, and commonly containing clay lenses and cavities. Geologic data from drillers' logs indicate that the top of the limestone of the Tampa Member is highly variable within the study area, ranging from $30 \mathrm{ft}$ above sea level to $54 \mathrm{ft}$ below sea level. A common remark on drillers' logs is the loss of circulation between 60 and $140 \mathrm{ft}$ below land surface, which could indicate solution cavities. Sand and clay are commonly found within the limestone unit far below the typical depth range of clastic deposits, which suggests that infilling and raveling of the overburden materials into cavities has occurred. Many domestic and production wells tap the Tampa Member in the study area. The Tampa Member is a poor to fair producer of water with yields ranging from a few to several hundred gallons per minute (Stewart, 1968).

The Suwannee Limestone underlies the Tampa Member and ranges from 200 to $350 \mathrm{ft}$ thick. The limestone is pure, white to light tan in color, soft and granular in appearance and contains abundant fossil detritus and organic structures such as casts, molds, and borings of mollusks and tests of Foraminifera and Bryozoa (Carr and Alverson, 1959). Many fossil molds within this unit give this rock type a high porosity. The Suwannee Limestone is a major contributor of water to production wells within the study area. Wells that tap this unit yield from several hundred to several thousand gallons per minute (Stewart, 1968).

\section{Lake Basin Geology}

The geologic description of the rocks and sediments that comprise the hydrogeologic units at each lake basin was defined through analysis of well cuttings, split-spoon core samples, geophysical well logs, and existing geologic information. The locations of these wells are shown in figures 3-5 and well numbers correspond to the index number in appendix A, which lists well construction information, and the hydrogeologic unit the well intercepts.

The surficial deposits at Dosson, Halfmoon, and Round Lake basins average $42 \mathrm{ft}$ in thickness and are similar in composition. The surficial deposits consist of an upper fine sand unit, a sequence of clayey sand, and a lower sequence of sandy clay (table 1). Contacts between these units are indistinct, but the cohesive nature of the sand increases with depth because of the higher percentage of clay. The uppermost deposit that underlies the three lake basins is a clean well-sorted, fine to very fine quartz sand. The sand is white to buff colored near the surface where it contains a mixture of organic matter and silt. Below this sand, the clay content gradually increases, creating a sequence of clayey sand. Below this sequence, where the clay content continues to increase, a unit of sandy clay is present.

The thickness of the intermediate confining unit is similar at Dosson Lake and Halfmoon Lake (approximately $6 \mathrm{ft}$ and $7 \mathrm{ft}$, respectively), based on split-spoon cores and natural gamma logs. The clay at both lakes has a dense plastic consistency, is a greenish-gray color, and contains varying amounts of sand and phosphate grains. The top of the intermediate confining unit is present at altitudes of 21 and $7 \mathrm{ft}$ above sea level at Dosson Lake and Halfmoon Lake, respectively (figs. 3 and 4; index numbers 74 and 63, respectively). The intermediate confining unit is much thinner at Round Lake than at the other two study lakes. The thickness of the unit was not readily apparent in the core sample but was confirmed using a natural gamma log. An isolated clay lens of less than $(<) 1 \mathrm{ft}$ was located at $11 \mathrm{ft}$ above sea level. Beneath this clay lens is a 4-ft thick sequence of clayey sand, which overlays the limestone of the Tampa Member (fig. 5, index number 22).

Based on geologic core samples collected from one deep well at each lake basin, the altitude of the Tampa Member is approximately 15,0 , and $7 \mathrm{ft}$ above sea level at Dosson Lake, Halfmoon Lake, and Round Lake, respectively (figs. 3-5; index numbers 73, 64, and 22). The limestone from the Tampa Member at the three lakes is white to light tan in color, microcrystalline, and contains fossils and traces of sand and clay. At Round Lake, a thin layer of silicon dioxide (chert) covers the limestone surface.

\section{Occurrence of Sinkholes in the Study Area}

Sinkholes are common in this mantled karst landscape and contribute to the highly variable geologic framework. Sinkholes result when limestone dissolves and cavities develop in the limestone. As these cavities expand, the overlying sand and clay subside into the solution openings forming depressions in the land surface. Between 1964-92, 334 sinkholes were reported in Hillsborough County (Shock and Wilson, 1996). Many of these sinkholes developed naturally; 
however, their increasing frequency corresponds to increases in urban development and ground-water withdrawals (Sinclair, 1982; Newton, 1986; Shock and Wilson, 1996; Tihansky, 1999).

Round Lake is located in a region that has experienced numerous sinkholes in recent decades. Many of these sinkholes were formed by abrupt changes in ground-water levels caused by pumping (Sinclair, 1982). In May 1964, 46 sinkholes formed near the Section 21 well field and Round Lake due to an increase in well-field pumping (Sinclair, 1982) (fig. 6). A decline in ground-water levels causes loss of support of overburden sediments over cavities (Newton, 1986). This type of sinkhole usually develops during the dry season (March through May) when ground-water levels are lowest and ground-water pumping rates are highest.

Sinkhole formation also is induced by increasing the volume of water that percolates downward through the sediments (Sinclair, 1982; Tihansky, 1999). During

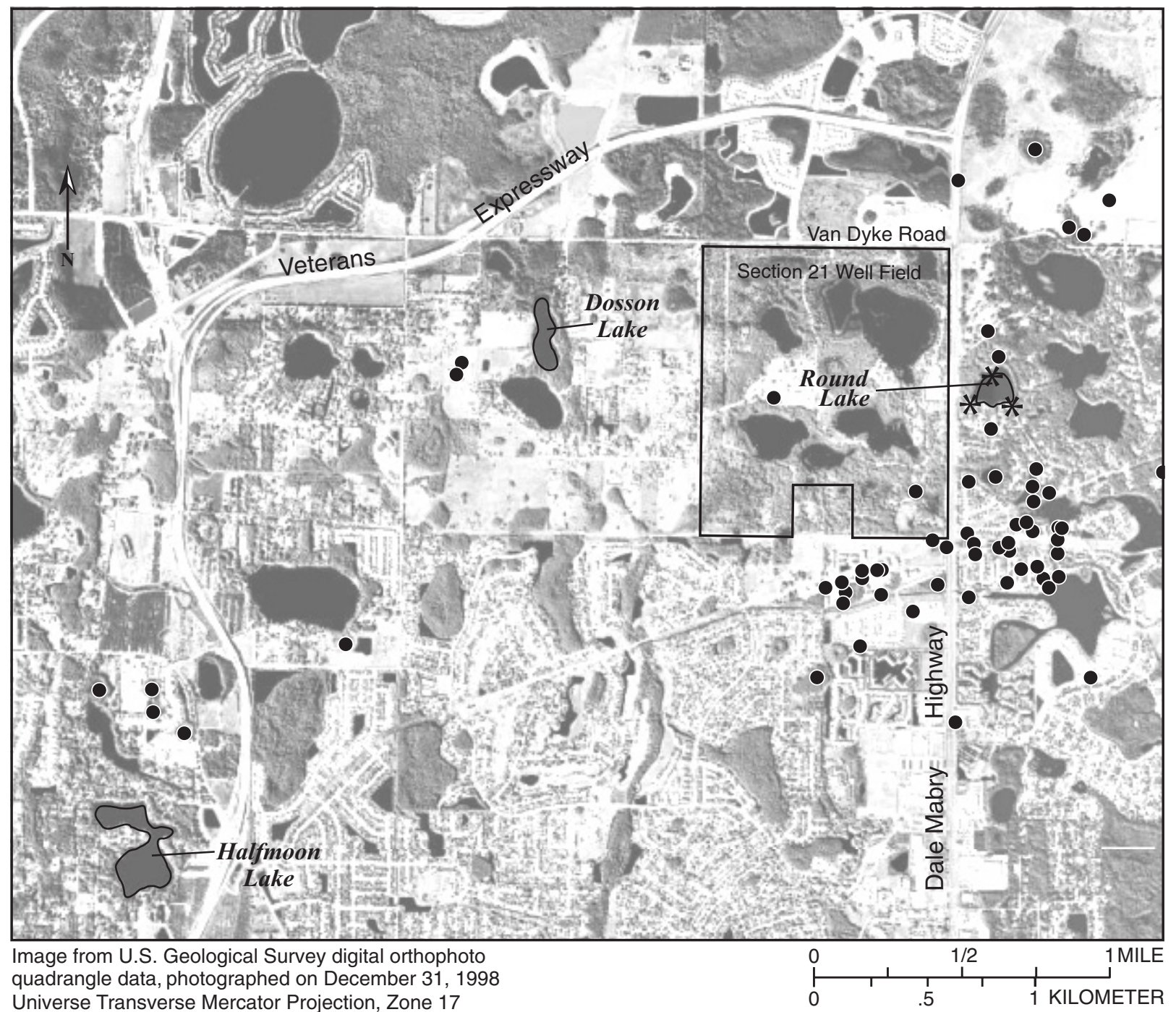

EXPLANATION

- LOCATION OF SINKHOLES DOCUMENTED SINCE 1964 (Sinclair, 1982; Shock and Wilson, 1996; and from aerial photos)

* Location of neW SinKHOLES formed DURING THE STUDY PERIOD

Figure 6. Documented sinkholes formed near the study lakes since 1964. 
this study, three new sinkholes were reported around the perimeter of Round Lake (fig. 6). The location and the timing of the sinkhole occurrences suggest that large amounts of lake leakage could have contributed to their formation. In areas where the sinkholes developed, steep lateral outflow gradients were observed between the lake and near-shore wells. Round Lake is also in an area where the intermediate confining unit is thin or highly breached, which leads to increased ground-water circulation. Additional evidence presented in the water-quality section of this report indicates that ground water in the Round Lake basin is unsaturated with respect to calcite and still has the capacity to dissolve limestone.

\section{Sublake Geology}

Analysis of the sublake geology is an important component to understanding the interactions between lakes and ground water. A combination of data analyses was used to define the sublake geology, which included bathymetry surveys, measurement of lake sediment thickness, and seismic-reflection surveys. By examining the sublake geology for each lake, distinctive features were observed that distinguished one lake from another, such as (1) depressions in the lakebottom configuration, (2) variability in thickness and composition of lake-bottom sediments, (3) thickness of sediments between the lake and the Upper Floridan aquifer (overburden thickness), and (4) irregularities in the sediments and limestone beneath the lakes that may represent possible routes of movement of water from the lakes.

\section{Bathymetry}

The bathymetry of each lake was defined using bottom-sounding techniques. Transects were run to define the geometry of each lake, and the transect orientation and perimeter of the lake were defined by using a differential Global Positioning System (GPS). In some instances, soundings were impeded near the perimeter of the lake due to vegetation growth or private docks.

All three lakes are relatively shallow (average depth of $<10 \mathrm{ft}$ ) and include small circular to irregularly shaped depressions along the lake bottom that range from 15 to $28 \mathrm{ft}$ below the lake surface. Some of these depressions in the lake bottom are presumably natural piping features or sand columns, but some are probably the result of lake-bottom dredging. Prior to the establishment of environmental regulations, lakebottom sediments were dredged in many lakes in northwest Hillsborough County. Lake-bottom sediments were commonly dredged along the lake shoreline to elevate low lying areas for building purposes.

Dosson Lake is the shallowest of the three lakes with an average depth of approximately $8 \mathrm{ft}$ at a lake level of $51.48 \mathrm{ft}$ above sea level (fig. 7). The lake bottom is rather uniform except for two isolated deep depressions. The deepest depression (15-20 ft below the lake surface) at the northern end is due to dredging, according to several residents. A deep depression $(15 \mathrm{ft})$ at the southern end of the lake may be a subsidence feature. Seismic-reflection survey data provide evidence that the deep depression corresponds with a depression in the limestone surface beneath the lake.

The average depth of Halfmoon Lake is approximately $10 \mathrm{ft}$ at a lake level of $41.35 \mathrm{ft}$ above sea level (fig. 8). Deep depressions along the southern shoreline were identified as dredged areas by a Halfmoon Lake resident. Several depressions along the lake bottom could be subsidence features, but this could not be confirmed during this study because of the dredging. One deep area, ( $28 \mathrm{ft}$ below the lake surface) at the north end of the lake, is far enough away from the shoreline to suggest that it is a subsidence feature. Data discussed in the seismic-reflection survey section of this report indicate that this deep depression corresponds with a depression in the limestone surface beneath the lake.

Of the three study lakes, the Round Lake bottom sediments appear to have been dredged most extensively. Round Lake has an average depth of approximately $9 \mathrm{ft}$ at a level of $52.52 \mathrm{ft}$ above sea level and has several deep depressions (20-25 ft below the lake surface) along the northern and western shoreline (fig. 9). Lake-bottom dredging at Round Lake has been documented in a report by Stewart and Hughes (1974) and confirmed by verbal communication with local residents. Similar to Halfmoon Lake, the depressions along the bottom of Round Lake could be subsidence features but this could not be determined during the study because of the dredging. However, based on geologic characteristics of the Round Lake basin, it is probable that one to several of these depressions are natural subsidence features. 


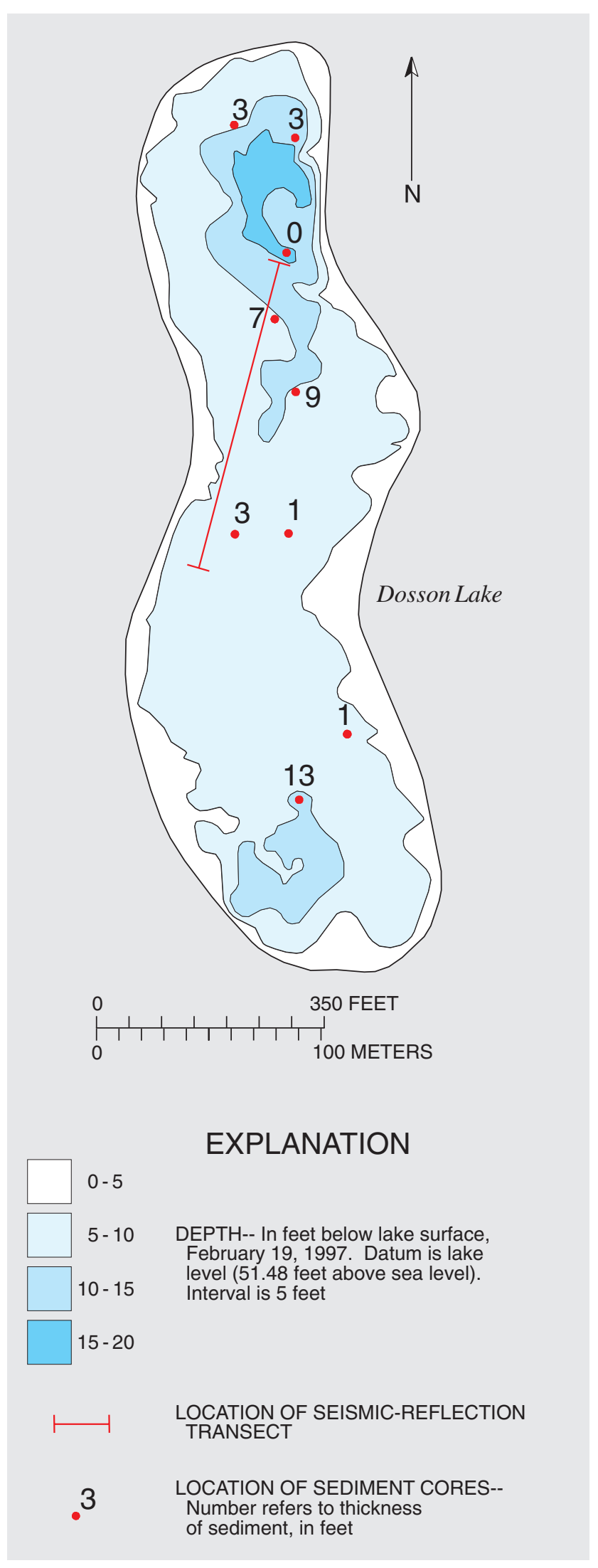

Figure 7. Bathymetry and soft sediment thickness for Dosson Lake.

\section{Lake-Sediment Thickness}

Sediment cores were collected at each lake to determine the distribution and thickness of the soft, organic lake-bottom sediments. The distibution and thickness of the soft sediment indicates the general degree of lake bottom permeablity at each lake. Nine sediment cores were collected in each lake to achieve approximately equal coverage of the lakes (Hakanson and Jansson, 1983). At each coring site, metal rods of uniform length were forced through the soft organic sediment until the hard lake bottom was contacted. Soft sediment cores were then extracted from the lake bottom using a piston corer, which contained a clear plastic core barrel that allowed visual inspection of the profile. The cores were measured, described, and photographed for archival purposes. Sediment cores also were collected for paleolimnological analysis at each lake to help determine the historical water quality of the lakes. Brenner and Whitmore (1999) provide a detailed account of the paleolimnological reconstruction from these sediment cores.

Dosson Lake had the deepest and most extensive distribution of soft, organic lake-bottom sediments. The loosely consolidated brown-gray sediment had a gelatinous consistency and in some areas was intermixed with sand and clay. The soft sediment distribution was highly variable and ranged from 0 to $13 \mathrm{ft}$ in thickness near the southern end of the lake (fig. 7). No soft sediments were found at a known dredged area near the northeastern shore, which suggests that the soft sediments were removed during the dredging process. The accumulation of soft sediment at the southern end of the lake may be related to sedimentation processes as the lake drains south towards Sunshine Lake.

The soft lake-bottom sediments at Halfmoon Lake were much thinner than at Dosson Lake. The softsediment thickness ranged from no sediment in several areas to approximately $4 \mathrm{ft}$ near the center of the lake (fig. 8). The brown-gray sediment had a gelatinous consistency and was intermixed with fine sand in several areas.

Round Lake had the thinnest accumulation of soft lake-bottom sediments and the most variablity in sediment composition of the three study lakes. Sediment thickness ranged from $<1 \mathrm{ft}$ to approximately $3 \mathrm{ft}$ near the center of the lake (fig. 9). The brown-gray organic sediment had a gelatinous consistency and in two of the cores, the organic sediment was mixed with clay and silt. A sparse layer of calcium carbonate 


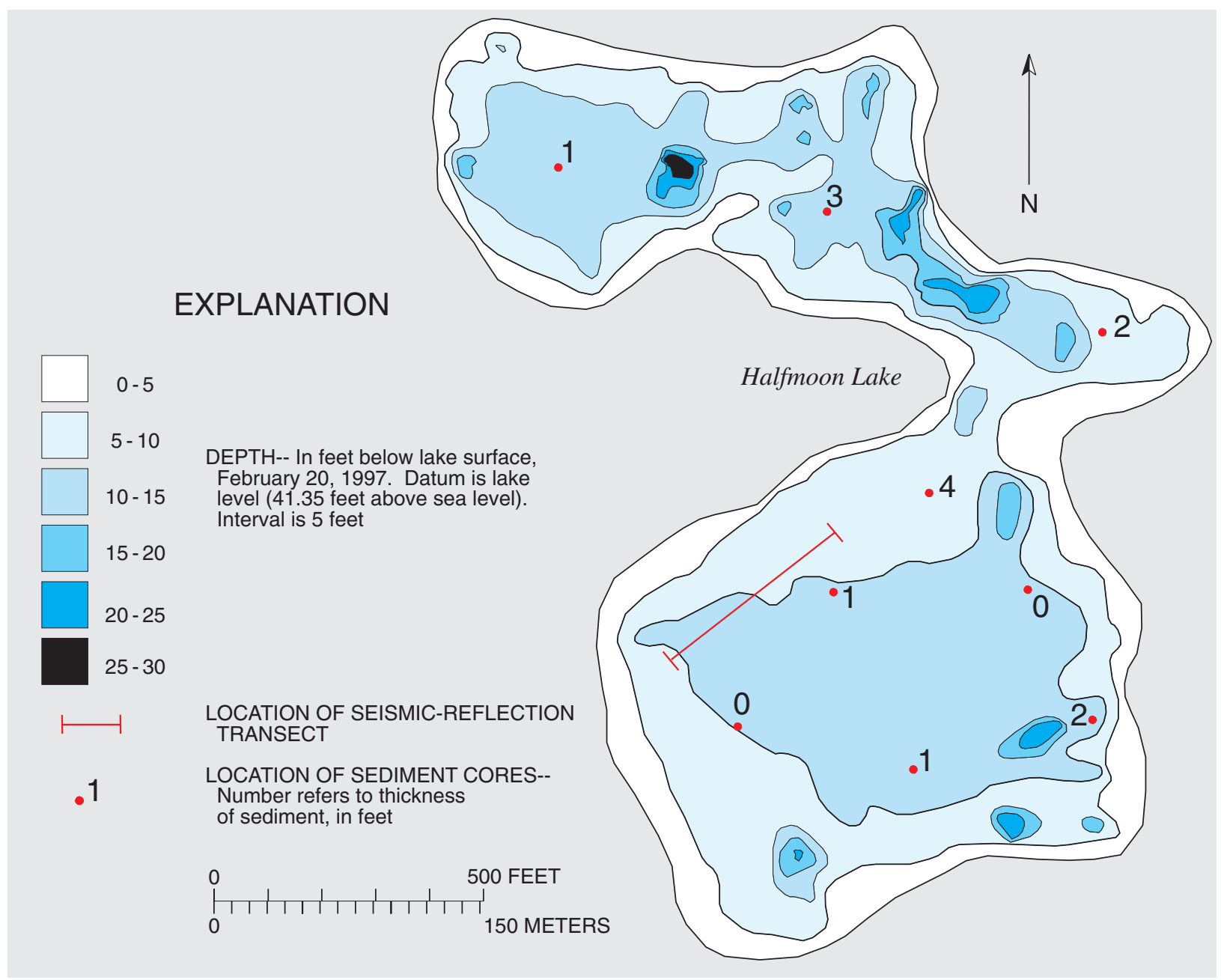

Figure 8. Bathymetry and soft sediment thickness for Halfmoon Lake.

precipitate was found on the lake-bottom sediments and was observed as a white, flocculant material. In seven of nine cores collected, the soft sediment was intermixed with shell material that was not found in the non-augmented lakes. The introduction of shell material and calcium carbonate precipitate in the organic sediments is the result of the ground-water augmentation. The calcium-bicarbonate enriched augmentation water has raised the alkalinity of the lake enabling snails such as Planorbella sp. to proliferate (Brenner and Whitmore, 1999). Shell material from the snails was present in the first $0.5 \mathrm{ft}$ of organic sediment.

In a sediment core collected for paleolimnological analysis at Round Lake, an approximate 1-ft thick peat deposit was located $2 \mathrm{ft}$ below the lake bottom near the center of the lake. This peat deposit was analyzed for carbon isotopes to determine the chronological date of the peat layer. The conventional carbon-14 $\left({ }^{14} \mathrm{C}\right)$ age of the peat was $6,970 \pm 80$ years $\mathrm{BP}$ (before present) and the ${ }^{13} \mathrm{C} /{ }^{12} \mathrm{C}$ ratio was -27.0 per mil. The age of the peat probably corresponds with the date of the formation of the lake, during the Holocene or Recent time period. Additional information is needed to determine why this peat was found at such a shallow depth and why the accumulation of sediment is low. Brenner and Whitmore (1999) suggest that organic sediment production has been low throughout the history of the lake and what little organic matter was produced could have been rapidly oxidized. Large water-level declines of $5 \mathrm{ft}$ in 1965-66 exposed much of the lake bottom, which undoubtedly altered the organic sediment accumulation. In addition, dredging may have removed much of the organic material or displaced the peat material. 


\section{EXPLANATION}

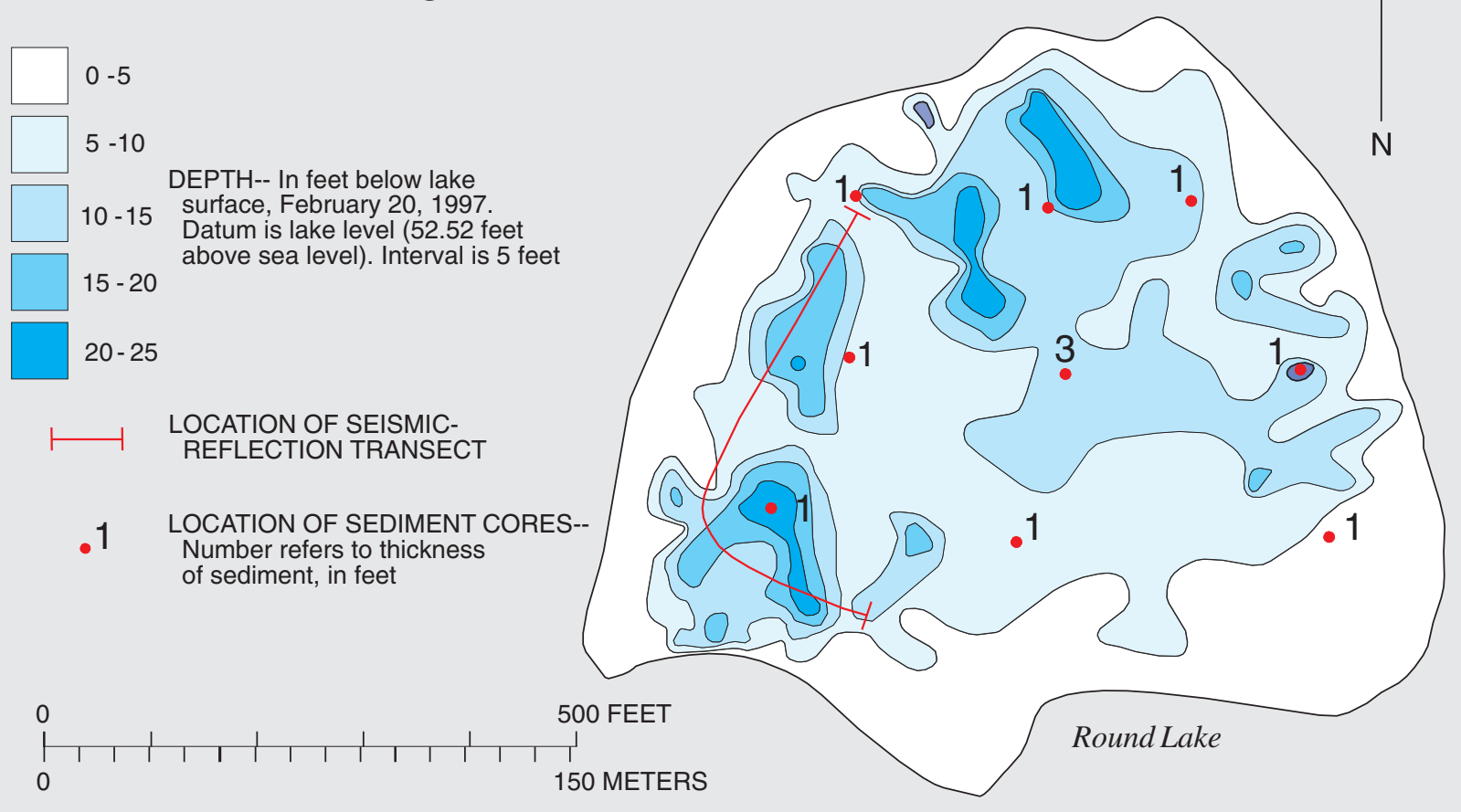

Figure 9. Bathymetry and soft sediment thickness for Round Lake.

\section{Seismic-Reflection Survey}

Structural features, thickness of overburden sediments, and depth to the Tampa Member below the lakes were defined by the use of high-resolution seismic-reflection methods. A number of seismicreflection transects were run to determine the geologic characteristics beneath each lake. The size of the lake and the types of features observed in the seismicreflection data determined the number and orientation of transects. Six transects showing seismic-reflection profiles were collected at Dosson Lake, 15 transects at Halfmoon Lake, and 19 transects at Round Lake. The seismic-reflection data were interpreted using standard methods where prominent sub-bottom reflectors and reflection characteristics were identified within the seismic-reflection profiles (Payton, 1977). The seismic data for each transect was assigned a depth scale based on 1,500 meters per second acoustic velocity for the sublake geologic material (Locker and others, 1988; Lee and others, 1991; Sacks and others, 1992; Kindinger and others, 1994; Tihansky and others; 1996; Lewelling and others, 1998). The major seismic- reflectors were correlated with drillers' logs and geologic data collected during this study to determine the characteristics of the geologic units beneath each lake. Kindinger and others (1994) and Tihansky and others (1996) provide detailed discussions pertaining to the methods and analysis of high-resolution seismicreflection in Florida lakes.

The seismic records for the three lakes exhibit several features that are typical of lakes of sinkhole origin. These features include a highly irregular limestone surface, discontinuous reflectors, low amplitude or reflection-free zones, and concordant parallel reflectors that commonly exhibit sagging structures (Tihansky and others, 1996). A representative seismic profile for each lake is shown in figure 10a-c.

Based on seismic reflection data, the surficial deposits (sand and clay units) vary in structure. The occasional presence of well-defined reflectors suggests that there are areas where the lateral bedding within surficial deposits are intact. In other areas of the seismic record, discontinuous reflectors and sagging structures suggest that the surficial deposits have been disrupted, which probably is due to subsidence. 


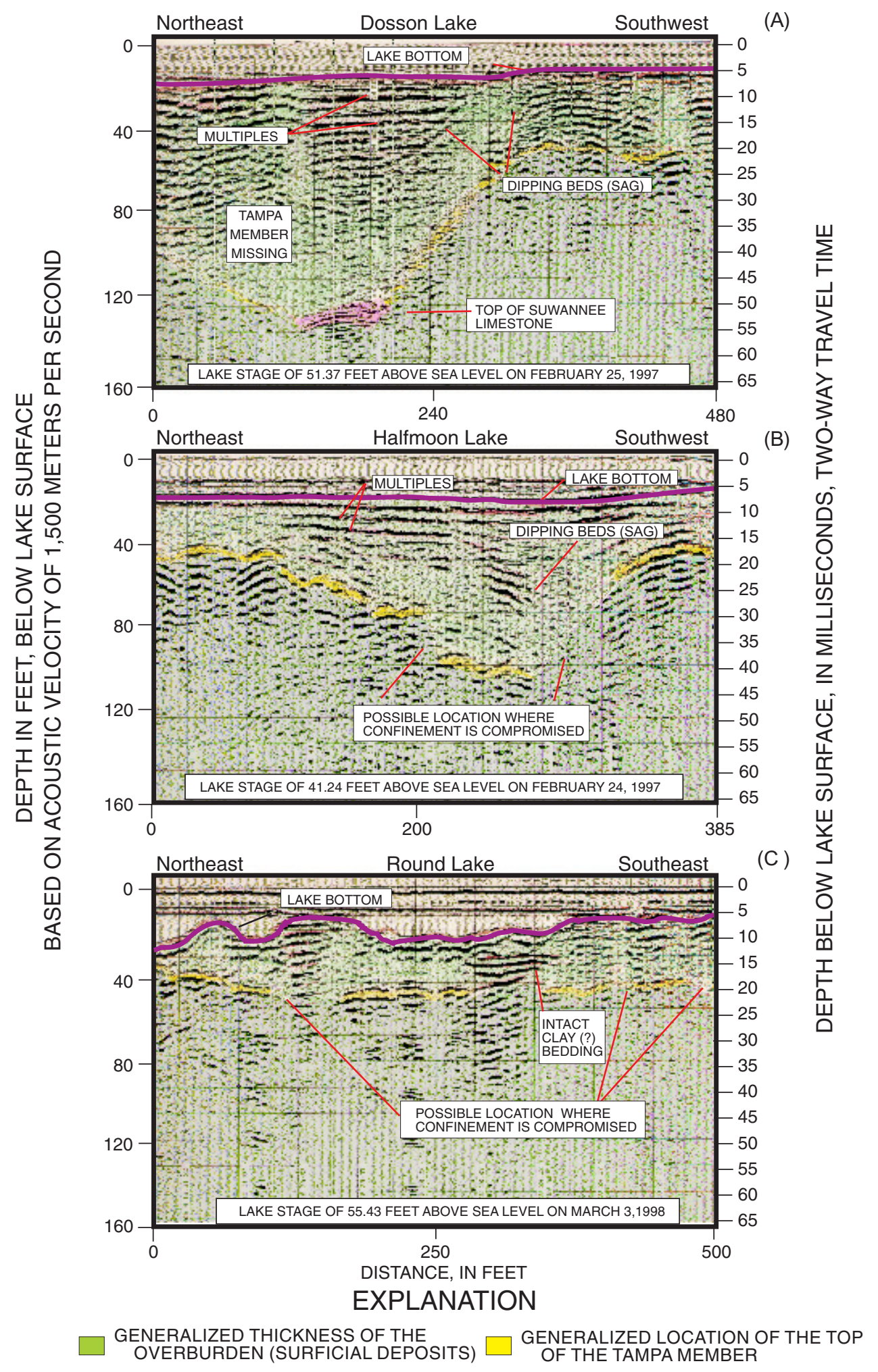

Figure 10. Seismic-reflection profile and interpretation of sublake geology for (A) Dosson Lake, (B) Halfmoon Lake, and (C) Round Lake. (Location of seismic-reflection transects are shown in figures 7-9.) 
Surficial deposits that are disrupted or exhibit a sagging structure, may indicate that the confinement is compromised in that area beneath the lake (fig. 10a-c). The intermediate confining unit could not be delineated beneath any of the lakes because the unit either was too thin to produce an identifiable reflector or was absent. It may be present, however, at the base of the surficial deposits.

The most consistently identifiable seismic reflector beneath each of the three lakes corresponds with the top of the Tampa Member. A high amplitude reflector is generated at the contact between the overburden material (surficial deposits) and the Tampa Member. The depth to the seismic reflector is highly variable, indicating the irregular nature of the limestone surface beneath the lakes. In some areas of each lake, the quality of the data limited the extent of the interpretations because of ringing multiples, which result from highamplitude returns from a sandy lake bottom.

The most distinctive feature in the seismic record for Dosson Lake was the great vertical relief to a lowamplitude reflector, which was not observed at the other study lakes. In areas of the seismic record where the low amplitude reflector was observed, the Tampa Member appears to be missing (fig. 10a). This low amplitude reflector correlated well with the top of the Suwannee Limestone, and in figure 10a, the reflector was observed in the seismic record at approximately $70 \mathrm{ft}$ below sea level. In other areas of the seismic record, the low-amplitude reflector ranged from 80 to $230 \mathrm{ft}$ below sea level. Where the Tampa Member was missing in the seismic record, the thickness of surficial deposits was much greater ( $>100 \mathrm{ft}$ thick) than the thickness observed in wells near Dosson Lake. In areas where the Tampa Member reflector was observed, the top of the limestone correlated with geologic logs in the Dosson Lake area. The Tampa Member reflector ranged from approximately 16 to $28 \mathrm{ft}$ above sea level, and the average overburden thickness was approximately $30 \mathrm{ft}$.

The most distinctive feature in the seismic record for Halfmoon Lake was the highly irregular limestone surface beneath the lake. Several areas of the seismic record indicate possible subsidence features, illustrated by the abrupt loss of the top of the limestone reflector, and accompanied by sags in the overlying reflectors (fig. 10b). Other features observed in the seismic record were hyperbolic point reflectors (not shown in fig. 10b). These reflectors suggest the presence of voids and cavities beneath the lake and provide additional evidence of subsidence. One of the hyperbolic point reflectors overlain by a depression in the lake bottom in the northern area may indicate that it is a natural piping feature. The top of the limestone reflector ranged from approximately $20 \mathrm{ft}$ above to $60 \mathrm{ft}$ below sea level, which is within the range that the Tampa Member was observed in wells near Halfmoon Lake. The average overburden thickness was approximately $40 \mathrm{ft}$.

The most distinctive feature in the seismic record for Round Lake was the lack of continuity of the Tampa Member limestone reflector (fig. 10c). Lack of continuity along this surface may indicate that the confinement is disrupted or compromised by localized subsidence or that the sedimentary structure exhibits karst features such as cavernous porosity. Evidence of cavernous porosity in the limestone in the Round Lake area includes frequent loss of circulation noted in remarks from driller's logs, a thin confining unit which leads to increased ground-water circulation, and increased occurrence of sinkhole development. The top of the limestone reflector beneath the lake ranged from approximately $4 \mathrm{ft}$ to $28 \mathrm{ft}$ above sea level. The average overburden thickness throughout the record was approximately $30 \mathrm{ft}$.

\section{GROUND-WATER FLOW PATTERNS}

Hydrologic data collected from a network of wells, lakes, and streams provided the basis for a description of ground-water flow near each of the study lakes. Monthly water levels were collected from a network of 100 surficial aquifer, 3 intermediate confining unit, 19 Upper Floridan aquifer wells, and 25 lake and stream measurement sites located throughout the three lake basins. The term "well nest," as used in this study, represents a cluster of wells that are drilled at the same location but completed at different depths. Well nests were used to determine the vertical-head distribution within an aquifer or between the surficial aquifer, the intermediate confining unit, and the Upper Floridan aquifer. At each lake basin, two well nests were located approximately 100 to $250 \mathrm{ft}$ from the edge of the lake. A surficial aquifer well nest consisted of three or four wells that were completed at different depths below the water table. A deeper well nest consisted of wells that were completed within the surficial aquifer, intermediate confining unit, and Upper Floridan aquifer. Continuous water-level monitors were placed at a surficial aquifer well and an Upper Floridan aquifer well at each 
lake to determine daily and seasonal water-level fluctuations. Appendix A lists an index number for each well location by latitude and longitude (identification number), well name, well depth and cased interval, hydrogeologic unit, and the summary of types of data collected at each well. Locations of wells with corresponding index numbers from appendix A are shown in figures 3-5. Monthly water-table maps were produced for Dosson Lake (January 1997 through May 1999; 29 months), Halfmoon Lake (August 1996 through May 1999; 34 months) and Round Lake (July 1996 through May 1999; 35 months) to delineate regions of ground-water inflow to and outflow from the lakes. Monthly potentiometric-surface maps of the Upper Floridan aquifer were produced (July 1996 thorough May 1999; 35 months) to determine seasonal trends. Monthly ground-water levels were published by the USGS in annual data reports for southwest Florida (Coffin and Fletcher, 1999b and 2000b).

\section{Ground-Water Flow Patterns Surrounding the Lakes}

Ground-water flow patterns around lakes can be classified according to the configuration of the surrounding water table (Krabbenhoft and others, 1994). Three general ground-water flow patterns were observed at the study lakes based on the seasonal configuration of the surrounding water table, which include a ground-water flow-through, discharge, and recharge pattern. A flow-through pattern is where ground-water inflow occurs around part of the lake perimeter and the remainder of the lake loses water to the ground-water system (fig. 11a). The flow-through pattern was the most prevalent ground-water flow pattern observed in this study and is common at other lakes in west-central Florida (Sacks and others, 1998). A ground-water discharge pattern is where groundwater inflow occurs around the entire lake perimeter because the adjacent water table is higher than the lake level (fig. 11b). This flow pattern usually occurs during periods of high recharge. A ground-water recharge pattern is where the lake level is higher than the surrounding water table and the lake loses water as lateral ground-water outflow (lake leakage) (fig. 11c). This pattern occurs naturally or results from artificially maintaining lake levels above the surrounding water table (Freeze and Cherry, 1979). These ground-water flow patterns are transitory and change in response to recharge conditions. For example, areas of ground-
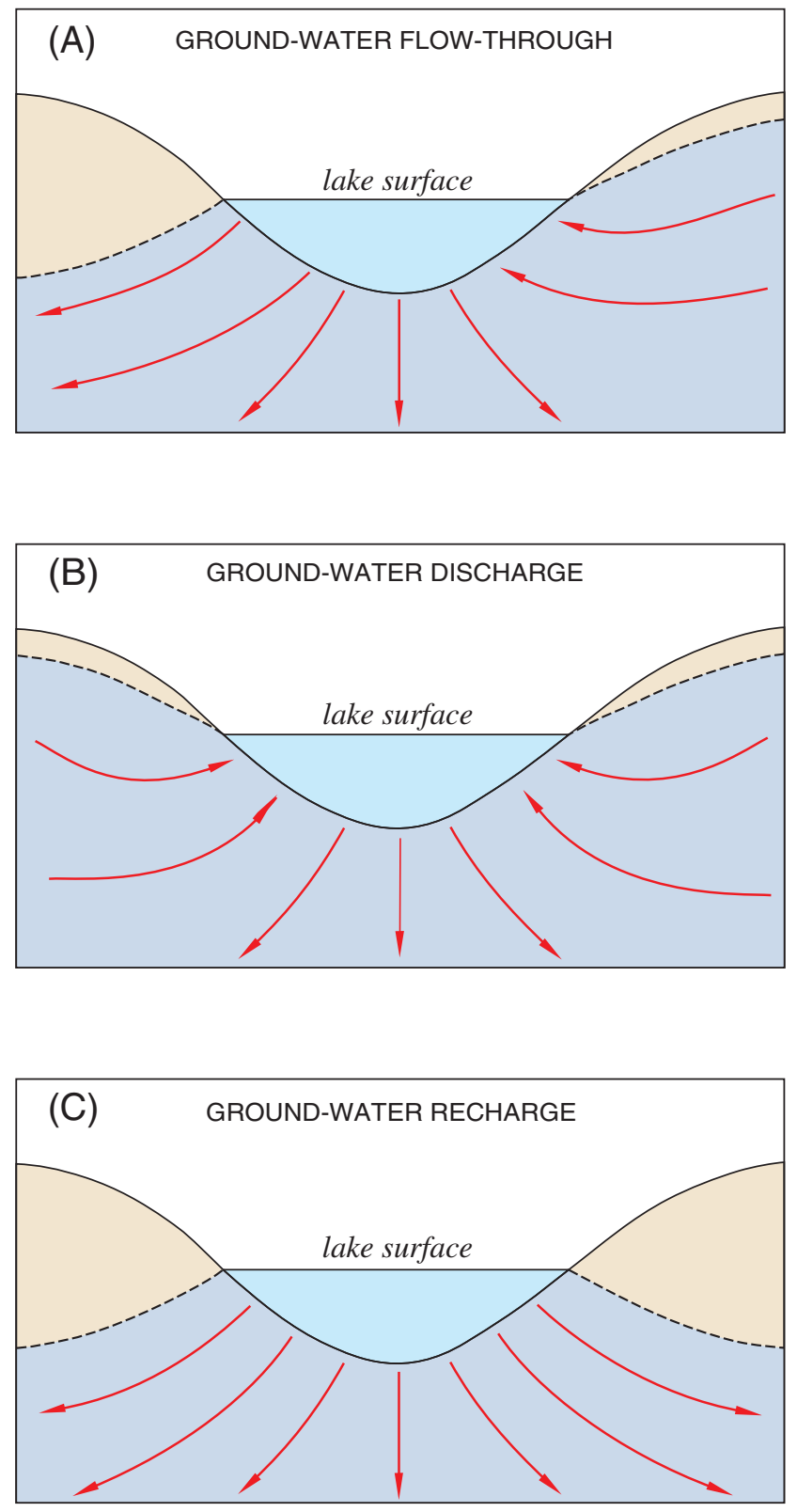

\section{EXPLANATION}

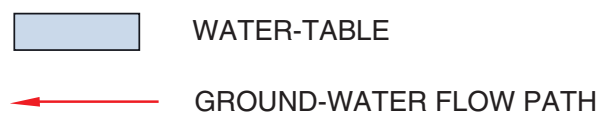

Figure 11. Three general ground-water flow patterns around lakes: (A) ground-water flow-through, (B) ground-water discharge, and $(C)$ ground-water recharge. (Modified from Winter and others, 1998.)

water inflow can change seasonally in response to cumulative recharge, or in shorter periods due to transient recharge mounds (Winter, 1986; Sacks and others, 1998; Lee, 2000). 
Dosson Lake experienced flow-through lake conditions for more than half of the study period (17 of 29 months). The percentage of the lake perimeter that received ground-water inflow during these months ranged from 10 to 80 percent. For most of the study period, ground-water inflow occurred along the east and west sides of the lake, where the water table was higher than the lake. The lake recharged the shallow ground-water system in the wetlands to the north and south of Dosson Lake, where the water table was lower than the lake. The water table was lower than the lake around much of the lake perimeter during dry periods, limiting the area of ground-water inflow (fig. 12a). The water table was lower than the lake around the entire lake perimeter during March through May 1999. This period corresponded with low rainfall and with the highest pumping rates from Section 21 well field for the study period. Therefore, the lack of ground-water inflow was probably due to a combination of low rainfall and increased pumpage. The gradients reversed during wet periods (fig. 12b), and ground-water inflow occurred around the entire lake perimeter ( 9 of 29 months). Therefore, the wetlands are a source of both recharge and discharge for Dosson Lake, depending on rainfall conditions.

Similar to Dosson Lake, Halfmoon Lake experienced flow-through lake conditions for much of the study period ( 27 of 34 months). The percentage of the lake perimeter that received ground-water inflow during these months ranged from 30 to 95 percent. For the entire study period, ground-water inflow occurred on the eastern and northern sides of Halfmoon Lake, where the water table was higher than the lake (fig. 12c). During average to dry periods, the lake recharged the water table on the western and southwestern sides of the lake, where the water table was lower than the lake. This lower water-table elevation may be controlled by the proximity to Rocky Creek. During wet periods, the water-table gradients reversed on the western and southwestern side of the lake and ground-water inflow occurred around the entire lake perimeter ( 7 of 34 months) (fig. 12d).

In contrast to the non-augmented lakes, lake leakage from Round Lake recharged the surrounding water table around the entire lake perimeter for much of the study period ( 23 of 35 months). The adjacent water table was lower than the augmented lake level and as a result, large volumes of lake water had the potential to flow out laterally in all directions (fig. 12e). High recharge or periods when the lake was not augmented caused ground-water inflow to occur around part of the perimeter of Round Lake (12 of 35 months). For example, ground-water inflow occurred on the northern and eastern side of the lake, with lake leakage occurring on the remaining sides during the El Niño period (January 1998) (fig. 12f). Round Lake responded as a flow-through lake during this period, which is probably the natural flow pattern of the lake if there was no augmentation or pumping at Section 21 well field. When the lake experienced flow-through patterns, the percentage of the lake perimeter that received ground-water inflow ranged from 10 to 80 percent.

The magnitude and direction of the head gradient between a lake and the adjacent water table will affect the amount of ground-water inflow and lake leakage. Changes in these gradients can be illustrated by comparing hydrographs of the study lakes with surficial aquifer water levels (fig. 13a-c). For example, water levels in two near-shore wells located on the western side of Dosson Lake and Halfmoon Lake (fig. 13a-b) were higher than the adjacent lake during much of the study period, indicating that ground-water flow was towards the lake. The gradients reversed slightly during dry periods and the lake recharged the surficial aquifer. The average lateral inflow head gradient for the study period was 0.007 foot per foot $(\mathrm{ft} / \mathrm{ft}$ ) between DL3 well (index no. 75) and Dosson Lake and $0.005 \mathrm{ft} / \mathrm{ft}$ between HML60 well (index no. 69) and Halfmoon Lake (table 2).

Following high recharge events at Dosson Lake and Halfmoon Lake, the water table temporarily rose to levels substantially higher than the lake (fig. 13a-b). Lateral inflow head gradients increased when watertable mounds occurred, which resulted in an increase in ground-water inflow at both lakes (table 2). Lee (2000) reported that transient water-table mounds following large rainfall events generated most of the net groundwater inflow to Lake Barco. Temporary water-table mounds receded to near lake levels after about a week for the two lakes. The recession period for these transient water-table mounds was considerably longer than for two lakes within the Central Lakes District of Florida (Lake Barco and Lake Starr), which typically lasted 1 day (Lee, 2000; Swancar and others, 2000). The longer recession period observed at Dosson Lake and Halfmoon Lake is probably due to less permeable surficial deposits in the study area than in the Central Lakes District. 

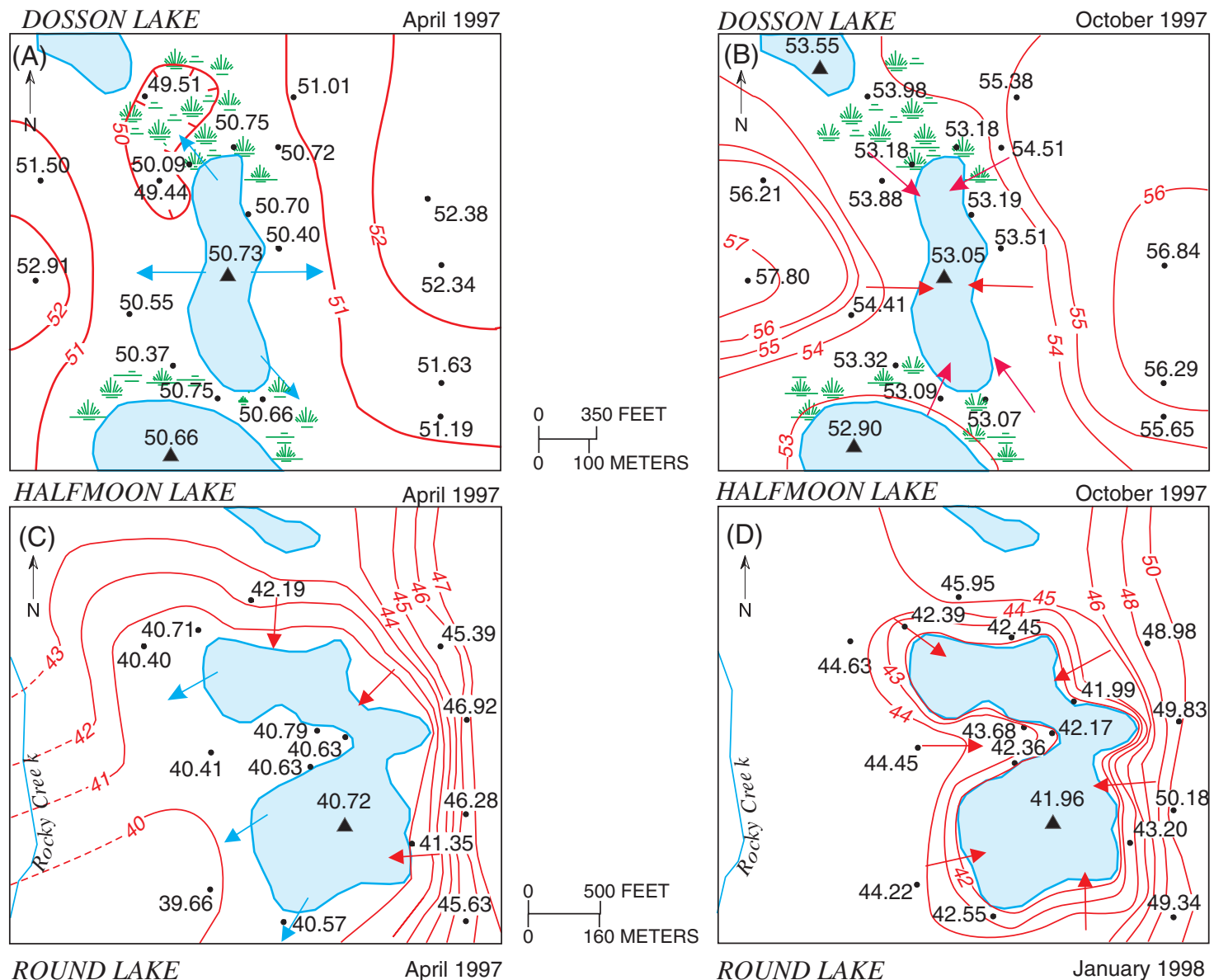

160 METERS
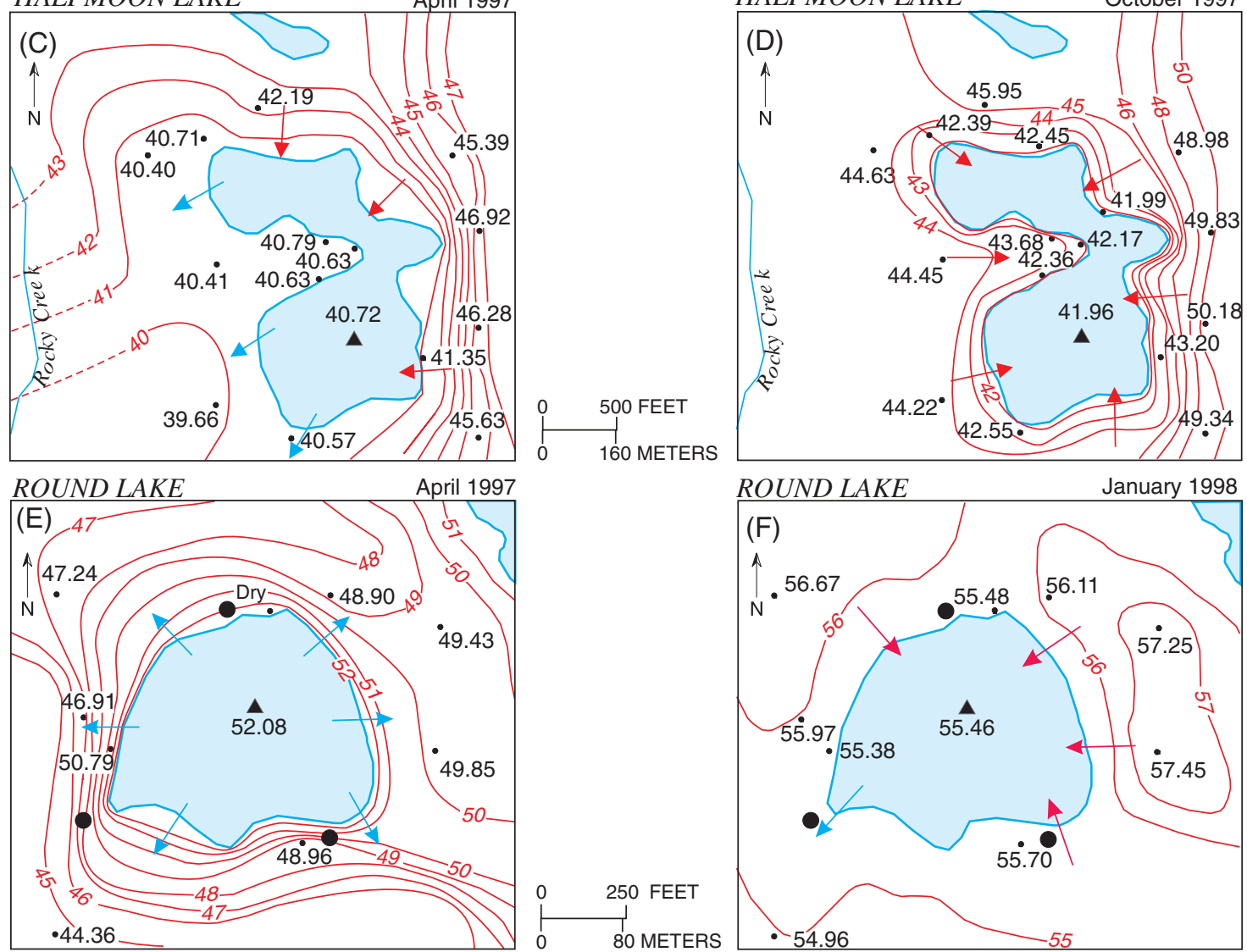

Base from U.S. Geological Survey digital data, 1:2,000,000, 1972

Albers Equal-Area Conic projection

Standard Parallels $29^{\circ} 30^{\prime}$ and $4530^{\prime}$, central meridian $-83^{\circ} 00^{\prime}$

\section{EXPLANATION}

WATER-TABLE CONTOUR--Shows altitude of water table in the surficial aquifer. Contour interval is 1 and 2 feet.

Datum is sea level.

$\longleftarrow$ GROUND-WATER OUTFLOW

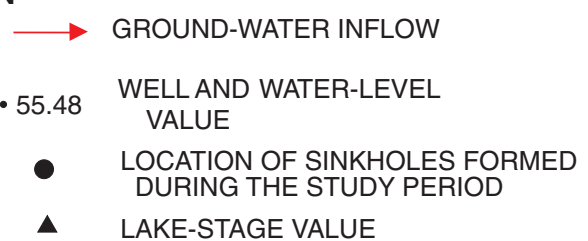

Figure 12. Interaction of ground water and lakes during a dry and wet period for (A-B) Dosson Lake, (C-D) Halfmoon Lake, and (E-F) Round Lake. 

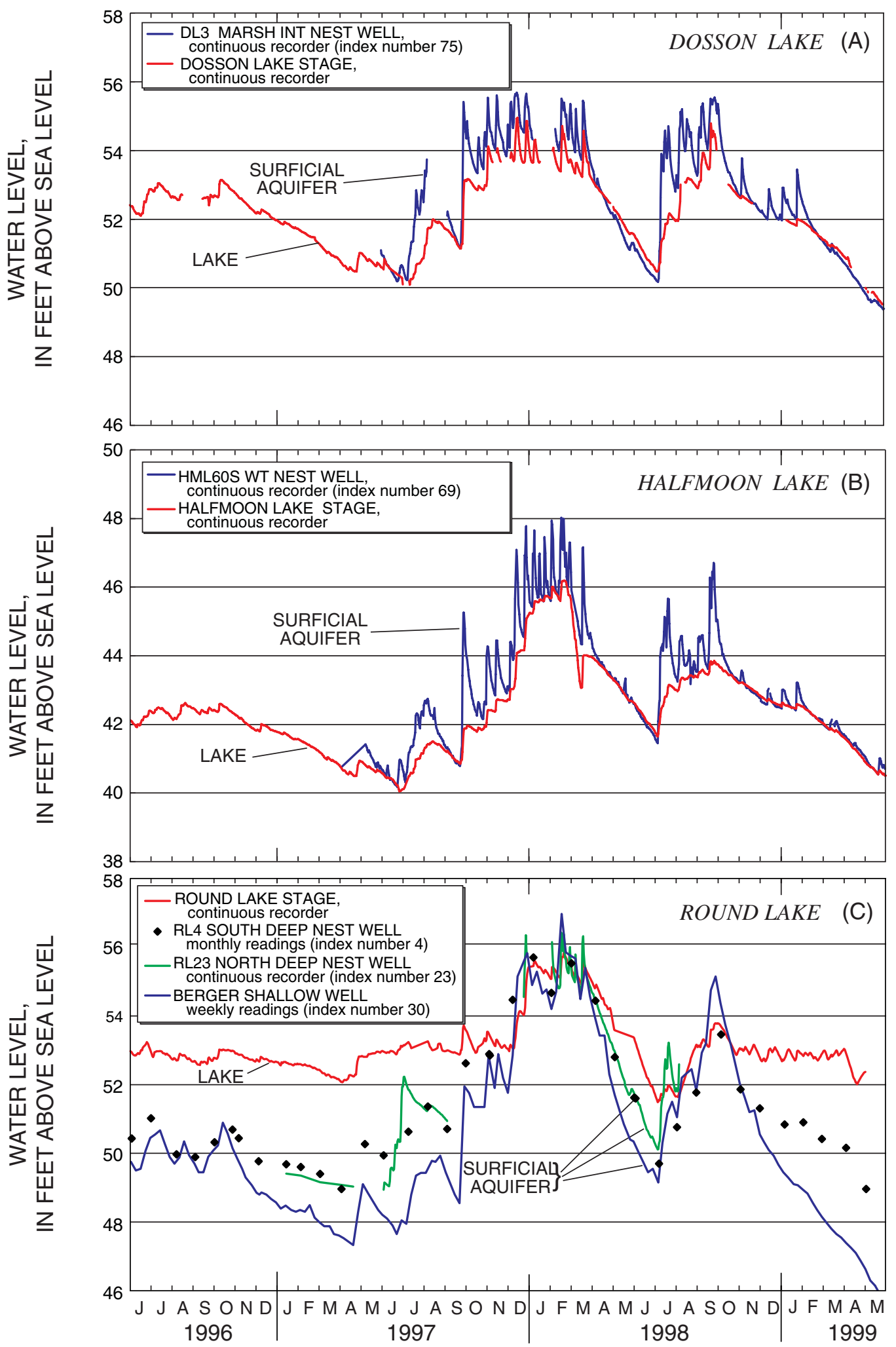

Figure 13. Water levels in selected surficial aquifer wells and lake levels for (A) Dosson Lake, (B) Halfmoon Lake, and (C) Round Lake. (Well construction data and index number are shown in appendix $A$ and locations of wells are shown in figures 3-5.) 
Table 2. Average and maximum lateral inflow and outflow head gradient within the surficial aquifer at Dosson Lake, Halfmoon Lake, and Round Lake

[units, gradient in foot per foot; -, indicates outflow gradient]

\begin{tabular}{|c|c|c|c|c|}
\hline Well name & $\begin{array}{l}\text { Average lateral } \\
\text { inflow head } \\
\text { gradient }\end{array}$ & $\begin{array}{c}\text { Maximum } \\
\text { lateral inflow } \\
\text { head gradient }\end{array}$ & $\begin{array}{l}\text { Average lateral } \\
\text { outflow head } \\
\text { gradient }\end{array}$ & $\begin{array}{c}\text { Maximum } \\
\text { lateral outflow } \\
\text { head gradient }\end{array}$ \\
\hline \multicolumn{5}{|c|}{ Dosson Lake } \\
\hline DL3 well (index no. 75) ${ }^{1}$ & 0.007 & 0.026 & -0.002 & -0.004 \\
\hline \multicolumn{5}{|c|}{ Halfmoon Lake } \\
\hline HML60 well (index no. 69) ${ }^{2}$ & 0.005 & 0.027 & -0.0005 & -0.001 \\
\hline \multicolumn{5}{|c|}{ Round Lake } \\
\hline RL 21 well (index no. 21$)^{3}$ & 0.0008 & 0.001 & -0.025 & -0.055 \\
\hline RL4 South well (index no.4) ${ }^{4}$ & 0.007 & 0.018 & -0.025 & -0.043 \\
\hline RL23 North well (index no. 23) 5 & 0.005 & 0.012 & -0.006 & -0.015 \\
\hline Dewey Thompson Sh. well (index no. 28) ${ }^{6}$ & 0.002 & 0.006 & -0.006 & -0.011 \\
\hline Berger Shallow well (index no. 30$)^{7}$ & 0.0004 & 0.0008 & -0.002 & -0.004 \\
\hline
\end{tabular}

${ }^{1}$ DL3 well is 110 feet west of Dosson Lake; continuous water-level recorder.

${ }^{2}$ HML60 well is 135 feet west of Halfmoon Lake; continuous water-level recorder.

${ }^{3}$ RL21 well is 30 feet west of Round Lake; monthly water-level measurements.

${ }^{4}$ RL4 South well is 80 feet south of Round Lake; monthly water-level measurements.

${ }^{5}$ RL23 North well is 105 feet north of Round Lake; continuous water-level recorder.

${ }^{6}$ Dewey Thompson Shallow well is 290 feet east of Round Lake; monthly water-level measurements.

${ }^{7}$ Berger Shallow well is 1,637 feet southeast of Round Lake; weekly water-level measurements.

In comparison to the other study lakes, the level of Round Lake was typically much higher than the adjacent water table (fig. 13c). This head difference creates a large lateral outflow gradient and is an important control on the magnitude of lake leakage at Round Lake. The lateral outflow gradient was largest around the margin of the lake and decreased further away from the lake (table 2). As a result, a large amount of lake leakage occurs around the margin of the lake and can be significant to the total sum of lake leakage (Lee, 2000 and Lee, 2002). Head differences were largest between the lake and the adjacent water table during May 1999, thus creating the maximum lateral outflow head gradient for the study period (table 2). During the study, three sinkholes developed near the margin of the lake, where the steepest lateral outflow gradients exist and where large volumes of lake leakage is directed (fig. 12e).

During and following extremely high rainfall periods, water levels in a number of wells surrounding Round Lake were higher than the lake level (fig. 13c). During these periods, a lateral inflow gradient occurred that resulted in ground-water inflow to the lake (table 2; fig. 12f).

\section{Vertical Flow Patterns Between the Lakes and the Upper Floridan Aquifer}

Vertical head loss between the lakes and the Upper Floridan aquifer varied at each lake basin, and the intermediate confining unit appears to be the dominant control on these vertical flow patterns. The average vertical head loss between the lakes and the Upper Floridan aquifer, determined from well nest data, was $16 \mathrm{ft}, 13 \mathrm{ft}$, and $11 \mathrm{ft}$ for Dosson Lake, Halfmoon Lake, and Round Lake, respectively. Differences in vertical head loss may indicate the localized nature of the confining unit sediments at each lake basin. For example, more permeable sediments in the intermediate confining unit will enhance the downward movement of recharge waters, resulting in a smaller head loss between the lake and the Upper Floridan aquifer. Hydrographs for the lakes and wells completed at different depths are shown in figures $14 \mathrm{a}-\mathrm{c}$.

Generally, heads in the surficial aquifer and Upper Floridan aquifer at Round Lake responded simultaneously to recharge from rainfall (fig. 15). These simultaneous responses indicate there is a hydraulic connection between the two aquifers. 

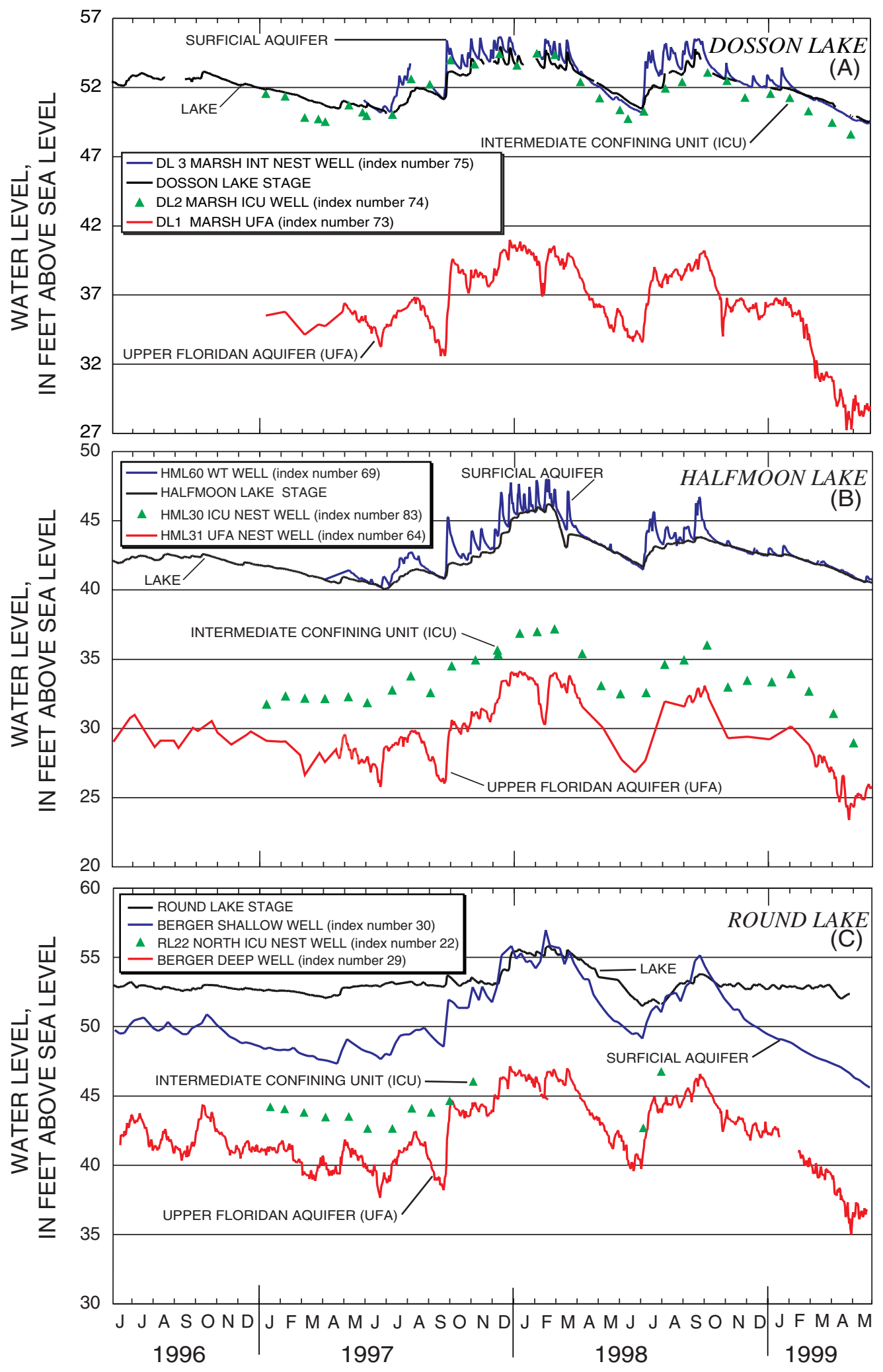

Figure 14. Water levels in wells completed at different depths and lake levels for (A) Dosson Lake, (B) Halfmoon Lake, and (C) Round Lake. (Well construction data and index number are shown in appendix $A$ and location of wells are shown in figures 3-5.) 


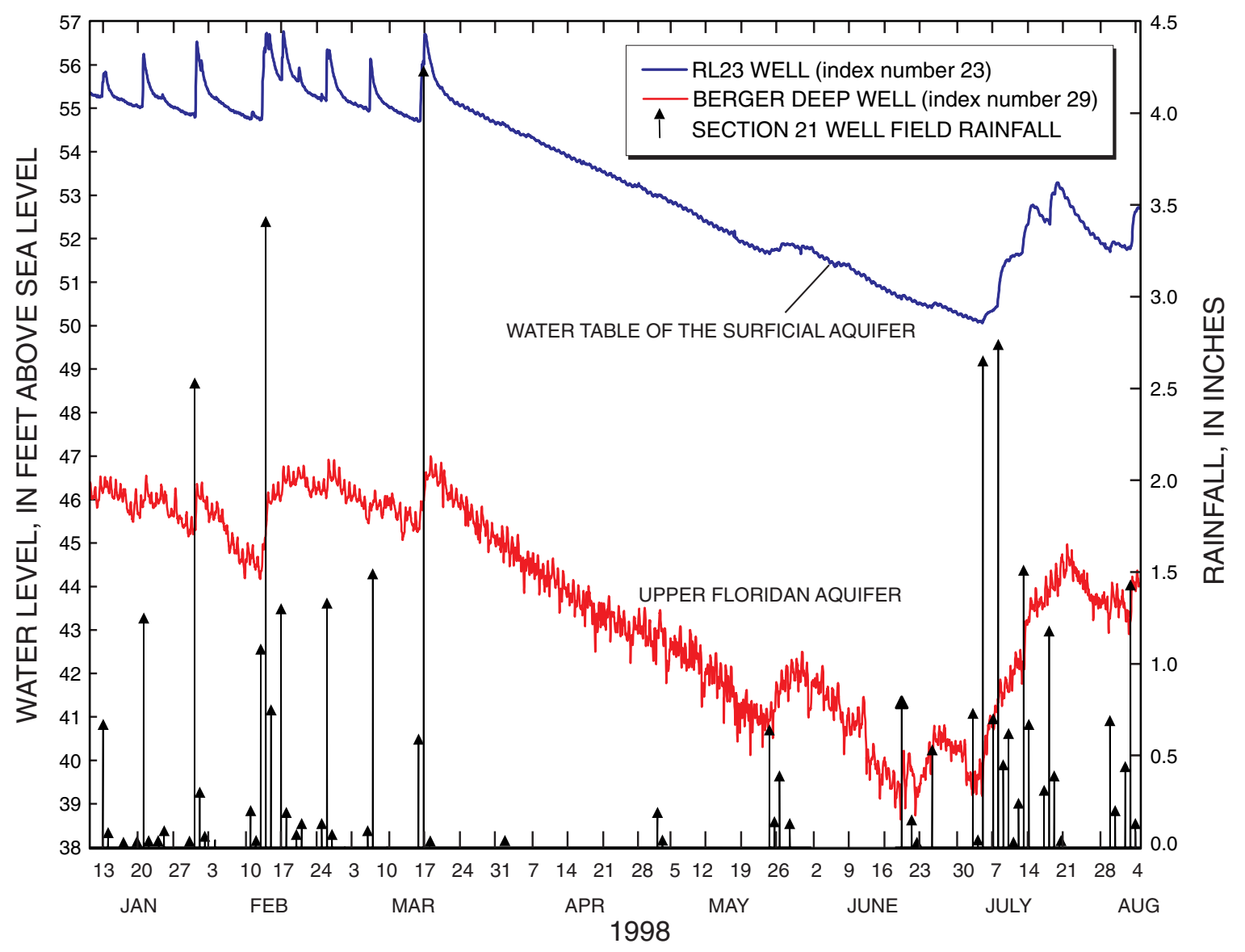

Figure 15. Response of the water table and the Upper Floridan aquifer to rainfall.

The rapid response of the Upper Floridan aquifer to recharge may be the result of sand-filled breaches in the intermediate confining unit, which can rapidly transmit recharge water downward to the Upper Floridan aquifer. Daily average heads in the surficial aquifer and the Upper Floridan aquifer at Round Lake were highly correlated $\left(r^{2}=0.91\right)$, which may indicate the degree of hydraulic connection between the aquifers. Lithologic data also indicate that there is less confinement at Round Lake than at the other study lakes. At Dosson Lake and Halfmoon Lake, the head relations between the two aquifers also were highly correlated, although to a lesser degree than Round Lake $\left(r^{2}=0.83\right.$ for Dosson Lake, and $\mathrm{r}^{2}=0.72$ for Halfmoon Lake).

Hydrogeologic sections across each lake basin, along with water-level data from wells completed at various depths, were used to compare the vertical flow regime between the non-augmented lakes and the augmented lake (figs. 16-18ab). The vertical head distributions directly beneath each lake were unknown.
Therefore, the heads below the lake were inferred from near-shore well nests and from the preliminary results of ground-water flow models for Halfmoon Lake and Round Lake. The hydrogeologic sections were constructed for a dry and wet period for each lake basin.

The vertical head decline within the surficial aquifer was small $(<2 \mathrm{ft})$ for the two non-augmented lakes (Dosson Lake and Halfmoon Lake) (figs. 16a-b and $17 \mathrm{a}-\mathrm{b})$. This small vertical head decline indicates there is a potential for significant horizontal flow in the upper part of the surficial aquifer. Head loss data also indicate the variability in hydraulic conductivity within and between hydrogeologic units. At all three lakes, small upward head differences were occasionally measured between wells that were located in the clayey sand intervals (between 17 and $22 \mathrm{ft}$ deep) and the uppermost sand unit. This head difference may indicate that deeper flow periodically is directed upward to areas of higher permeability within the surficial aquifer. 


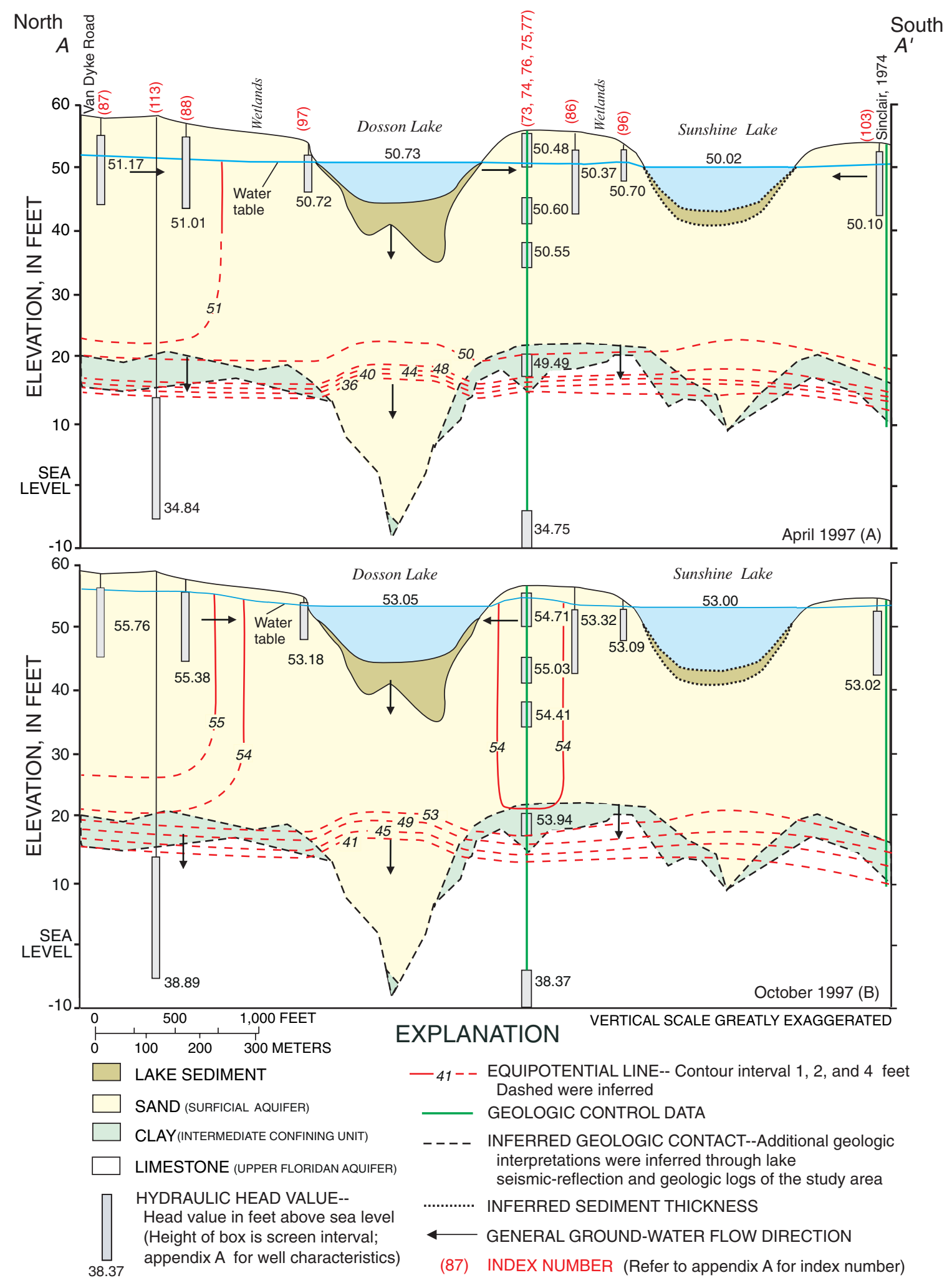

Figure 16. Vertical head distribution for (A) a low and (B) high water-level condition along hydrogeologic section $A-A^{\prime}$ for Dosson Lake. (Section location shown in figure 3.) 

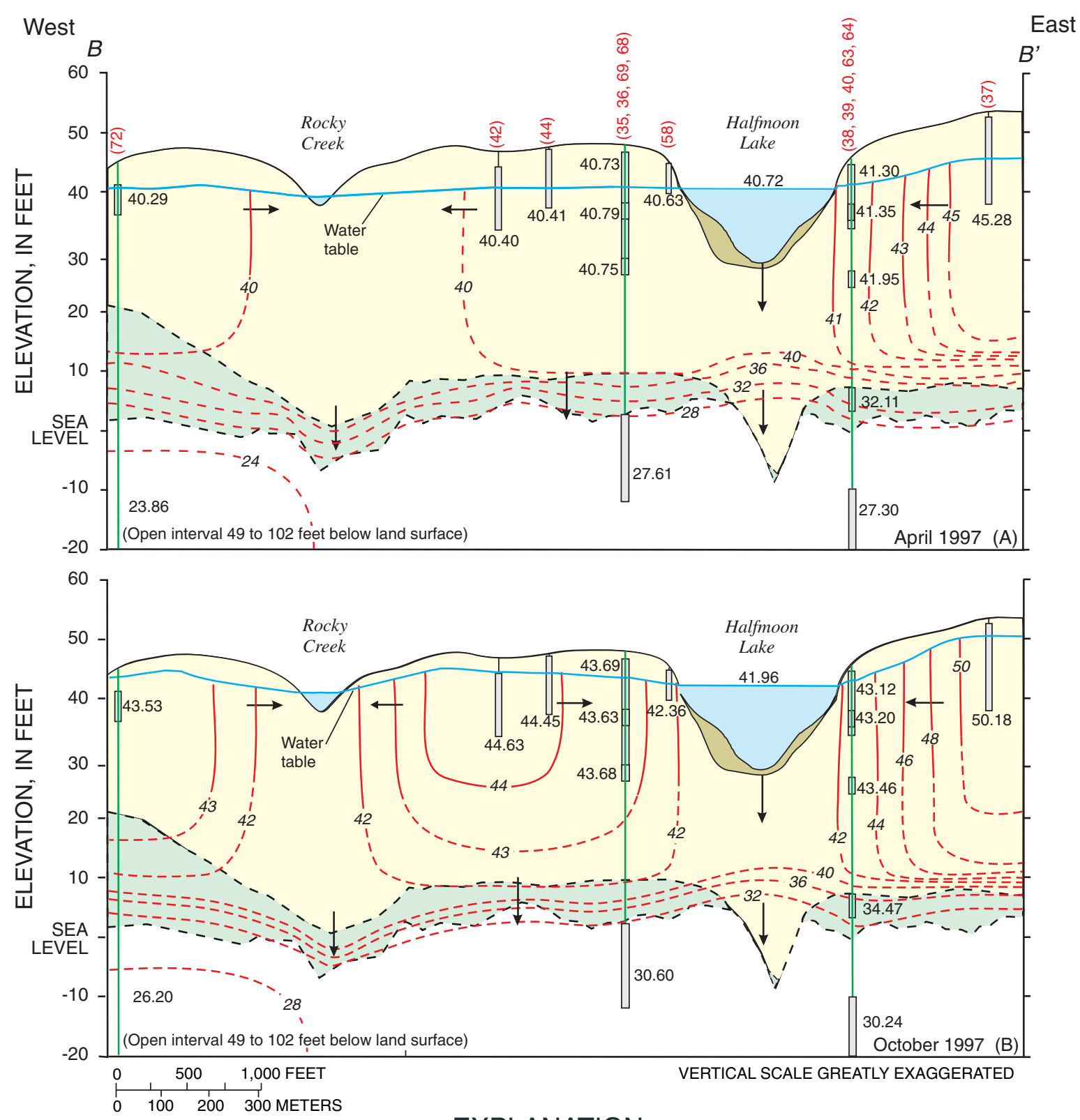

\section{EXPLANATION}

LAKE SEDIMENT

SAND (SURFICIAL AQUIFER)

CLAY (INTERMEDIATE CONFINING UNIT)

LIMESTONE (UPPER FLORIDAN AQUIFER) HYDRAULIC HEAD VALUE-Head value in feet above sea level (Height of box is screen interval; appendix A for well characteristics)

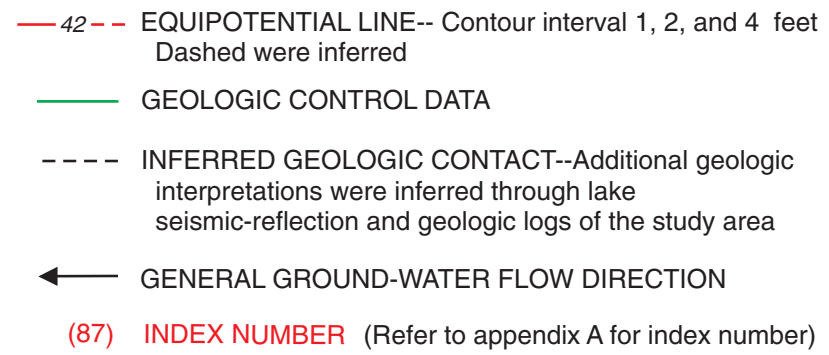

— 42-- EQUIPOTENTIAL LINE-- Contour interval 1, 2, and 4 feet Dashed were inferred

INFERRED GEOLOGIC CONTACT--Additional geologic interpretations were inferred through lake seismic-reflection and geologic logs of the study area

(87) INDEX NUMBER (Refer to appendix A for index number)

Figure 17. Vertical head distribution for (A) a low and (B) high water-level condition along hydrogeologic section B-B' for Halfmoon Lake. (Section location shown in figure 4.) 

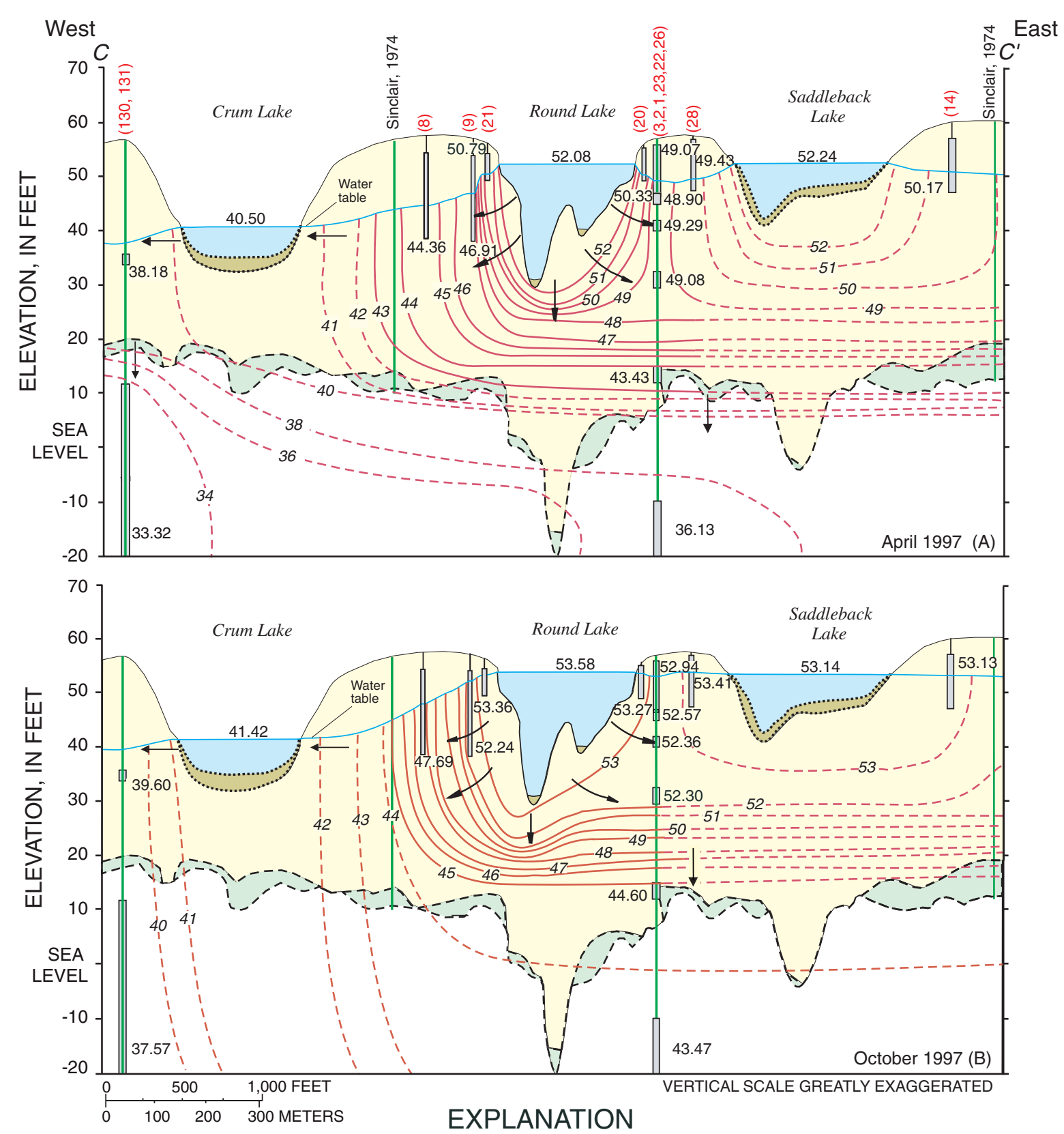

\section{LAKE SEDIMENT}

SAND (SURFICIAL AQUIFER)

CLAY (INTERMEDIATE CONFINING UNIT)

LIMESTONE (UPPER FLORIDAN AQUIFER) HYDRAULIC HEAD VALUE-Head value in feet above sea level (Height of box is screen interval; appendix A for well characteristics)

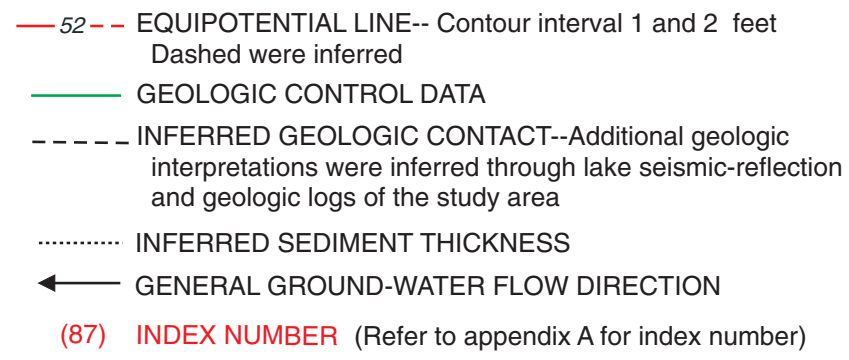

- 52- - EQUIPOTENTIAL LINE-- Contour interval 1 and 2 feet Dashed were inferred GEOLOGIC CONTROL DATA interpretations were inferred through lake seismic-reflection and geologic logs of the study area

(87) INDEX NUMBER (Refer to appendix A for index number)

Figure 18. Vertical head distribution for (A) a low and (B) high water-level condition along hydrogeologic section C-C' for Round Lake. (Section location shown in figure 5.) 
Most of the vertical head loss between the surficial aquifer and the Upper Floridan aquifer occurs across the intermediate confining unit at Dosson Lake and Halfmoon Lake. The vertical head loss across the intermediate confining unit was higher at Dosson Lake than at Halfmoon Lake and had slight seasonal variability at both lakes. The head loss across the intermediate confining unit at Dosson Lake was approximately $16 \mathrm{ft}$ during the dry season (fig. 16a) and approximately $14 \mathrm{ft}$ during the wet season (fig. 16b). The head loss across the intermediate confining unit at Halfmoon Lake was approximately $13 \mathrm{ft}$ during the dry season (fig. 17a) and approximately $12 \mathrm{ft}$ during the wet season (fig. 17b).

Round Lake had a much greater vertical head loss within the surficial aquifer (approximately $9 \mathrm{ft}$ ), compared to the non-augmented lakes $(<2 \mathrm{ft})$ (fig. 18a-b). The head loss across the intermediate confining unit was lower at Round Lake (1-7 ft) than at the other study lakes, indicating that the intermediate confining unit is more permeable, breached, or thinner at Round Lake. Where the intermediate confining unit is thin or breached, there is a greater tendency for downward flow through the surficial aquifer and intermediate confining unit. Generally, lakes that reside over a thin or highly breached intermediate confining unit, such as Round Lake, will require more augmentation to maintain lake levels than lakes where the intermediate confining unit is thicker or more intact.

\section{Upper Floridan Aquifer Flow Patterns}

Heads in the Upper Floridan aquifer decrease from east to west across the study area, and the lateral head gradient is approximately $5 \mathrm{ft}$ per mile (fig 19a-b). The highest heads measured in the Upper Floridan aquifer during the study period was during the unusually wet El Niño period (March 1998), when recharge rates were highest and well-field pumping was lowest for the study period (fig. 19a). The lowest heads in the Upper Floridan aquifer were measured in May 1999, after an extended dry period, and when well-field pumping was the highest for the study period (Southwest Florida Water Management District, 1999). The May 1999 heads were approximately 8 to $12 \mathrm{ft}$ lower than the March 1998 heads (fig. 19b).

Heads in the Upper Floridan aquifer have decreased in the study area because of increased ground-water use. The long-term average head decline (1963-99) at Section 21 well field is approximately $12 \mathrm{ft}$ (Hillsborough 13 Deep well; index number 130).
During the study period, withdrawals at Section 21 well field averaged about 10 million gallons per day (Mgal/d) (Southwest Florida Water Management District, 1999). Withdrawals from Section 21 well field and other water uses have created a cone of depression encompassing Round Lake and adjacent areas of northwest Hillsborough County (fig. 19a-b). Other water uses include small citrus groves, nurseries, and golf courses, but the withdrawals for these uses are much smaller than the withdrawals for public supply. The cone of depression at Section 21 well field was not reflected in the regional potentiometric surface map for May 1999 (Duerr and Torres, 2000) due to a limited number of wells measured, and because it is somewhat masked by the regional cumulative drawdown in the area. In addition to the Section 21 well field, two other well fields are located near Halfmoon Lake (CosmeOdessa, and Northwest Hillsborough Regional; fig. 1). The local effect of these well fields on the heads of the Upper Floridan aquifer is similarly not obvious due to a limited number of wells measured. The average pumping rates for Northwest Hillsborough Regional and Cosme-Odessa well fields for the study period was 9 and $11 \mathrm{Mgal} /$ day, respectively (Southwest Florida Water Management District, written commun., 2001).

Heads in the Upper Floridan aquifer at each lake basin had similar monthly trends but the timing and magnitude of hourly water-level fluctuations differed (fig. 20). Hourly water-level fluctuations in the Upper Floridan aquifer were caused by changes in localized pumping within each lake basin. Short-term drawdowns in Upper Floridan aquifer wells at the three lake basins ranged from approximately 0.10 to $1 \mathrm{ft}$. Water levels recovered after approximately 2 to 7 hours.

\section{WATER BUDGET}

A water-budget approach was used to compare the differences in net ground-water flow rates for the two non-augmented lakes (Dosson Lake and Halfmoon Lake) to the augmented lake (Round Lake). The water budget defines the balance of inflows and outflows to and from the lake and is an important tool in understanding lake/ground-water interactions. A waterbudget approach has been used to determine the net ground-water flow for a number of lakes in central Florida. A detailed description of the water-budget approach for other lakes in central Florida is discussed in reports by Lee and others (1991), Sacks and others (1992, 1998), and Swancar and others (2000). 

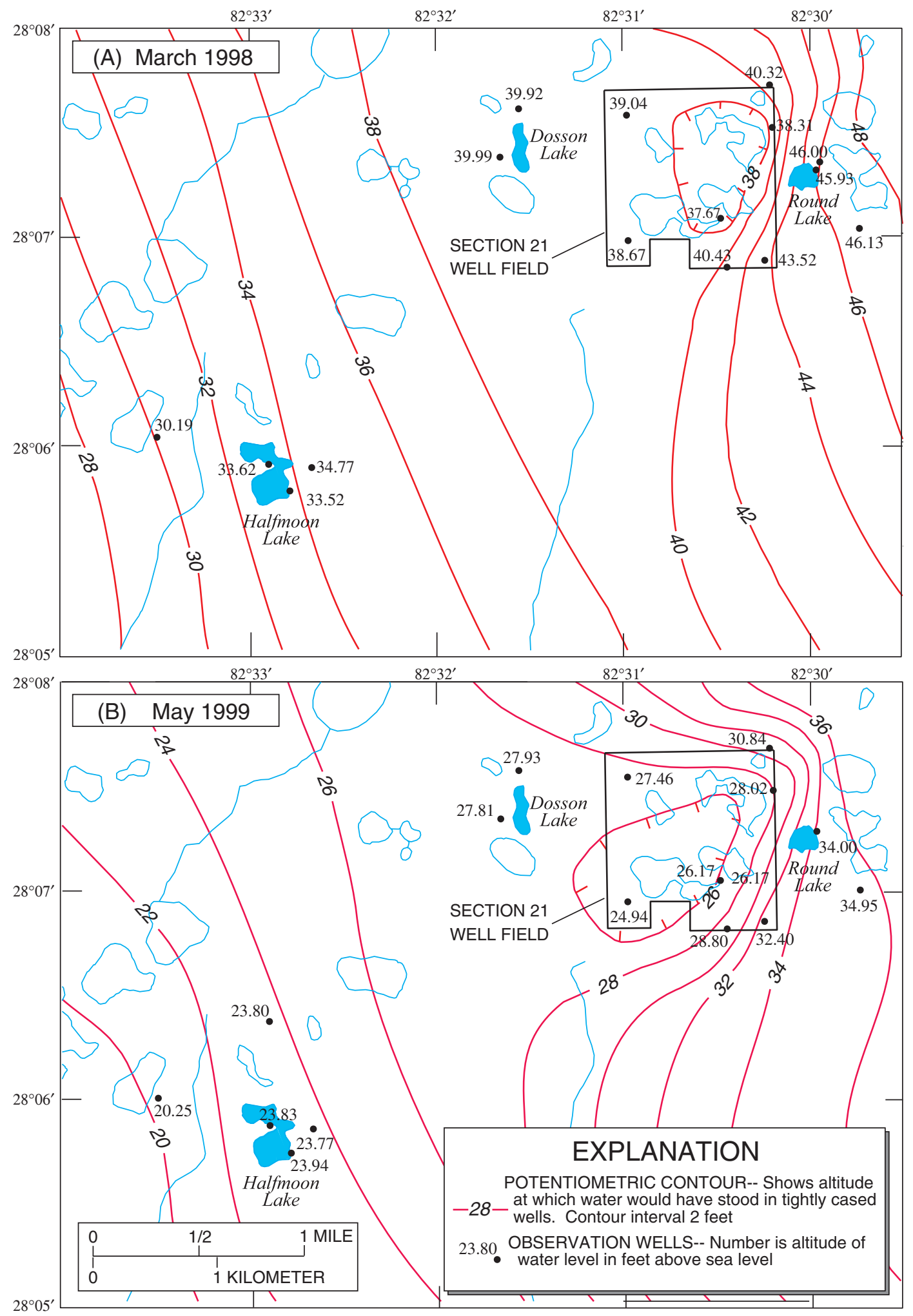

Figure 19. Potentiometric surface of the Upper Floridan aquifer for $(A)$ high head condition (March 4, 1998) and (B) low head condition (May 5, 1999). 


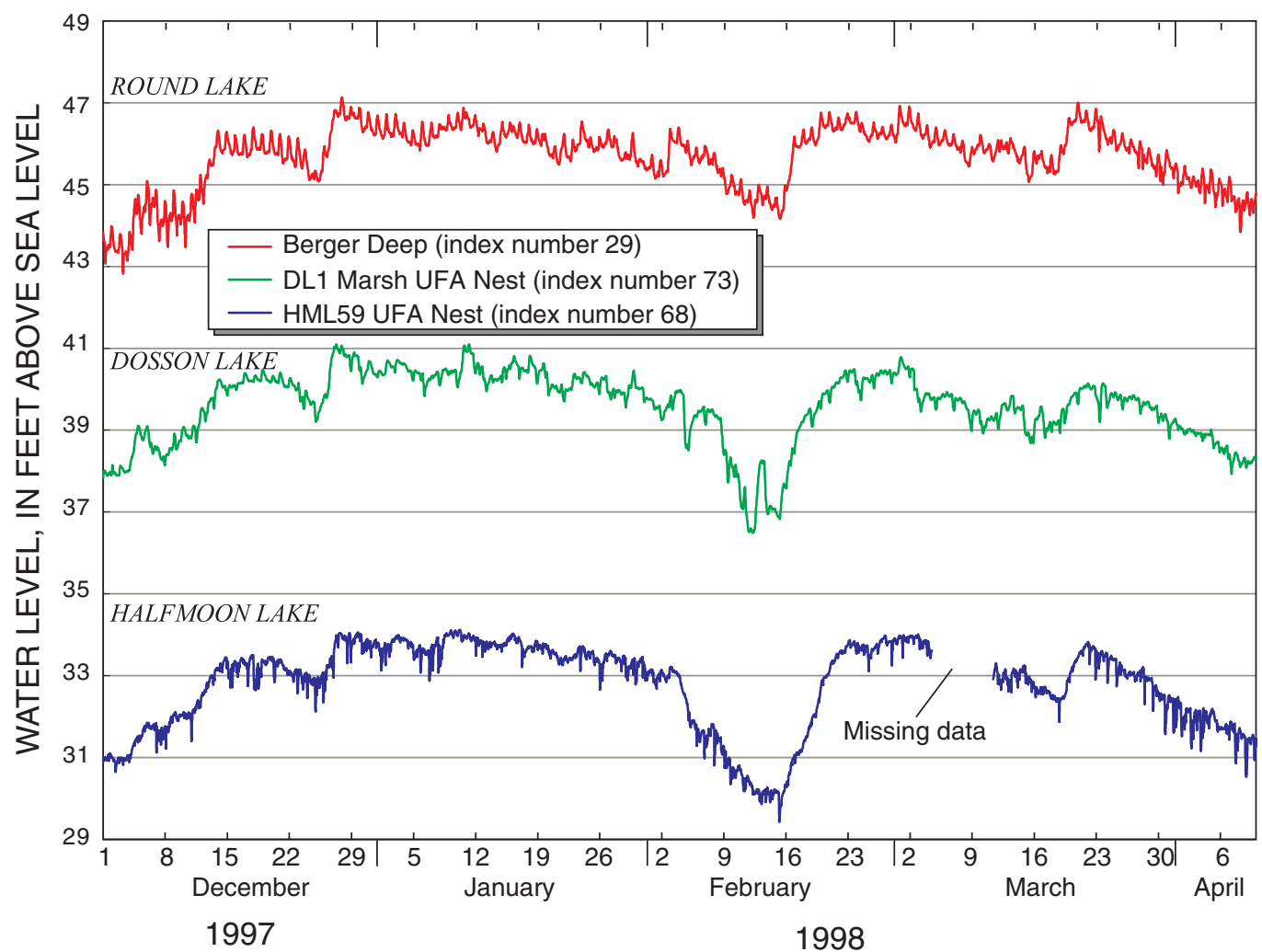

Figure 20. Fluctuations of water levels within the Upper Floridan aquifer near Dosson Lake, Halfmoon Lake, and Round Lake. (Well construction data and index number are shown in appendix $A$ and location of wells is shown in figures 3-5.)

\section{Methods}

A water budget was computed monthly, between June 1996 and May 1999, for each lake. The following is the general water budget equation:

$$
\begin{gathered}
\Delta S \pm e \Delta S=P-E+A+S_{i}-S_{O}+G_{i}-G_{O} \\
\pm e P \pm e E \pm e A \pm e S_{i} \pm e S_{O} \pm e G_{i} \pm e G_{O}
\end{gathered}
$$

where $\Delta S$ is the change in lake volume over a given time period, $P$ is precipitation, $E$ is lake evaporation, $A$ is total ground-water augmentation, $S_{i}$ is surface-water inflow, $S_{O}$ is surface-water outflow or direct pumping from the lake, $G_{i}$ is ground-water inflow, $G_{O}$ is groundwater outflow, and $e$ is the error or uncertainty in each budget term for the same time period. Water-budget components are expressed in linear units (inches) for this report. Linear units were used so water-budget terms could easily be compared between lakes that have different surface areas, and they were computed by dividing the change in lake volume and volumetric fluxes by the average lake surface area for the month. Average lake surface area was included in the waterbudget tables so that volumetric units could be readily obtained.

Errors or uncertainties in water-budget terms result from measurement error, extrapolation of regional data to site-specific data, and uncertainties in computed or assumed parameters used to calculate the water-budget term (Winter, 1981). Quantifying these uncertainties is extremely important to the interpretation of the final water budget, especially the net ground-water flow term (Winter, 1981). The assumed uncertainties in lake storage (5 percent), rainfall (5-15 percent, depending upon the gage location), evaporation (20 percent), and surface-water inflows and outflows (50 percent) were obtained from previous studies 
(Winter, 1981; Lee and Swancar, 1997; Sacks and others, 1998; Swancar and others, 2000). The uncertainty for ground-water augmentation was 5 percent, based on frictional loss through a pipe (Driscoll, 1986).

To determine net ground-water flow ( $G_{\text {net }}$, ground-water inflow minus ground-water outflow), the water budget equation (eq. 1) was rearranged as follows:

$$
G_{\text {net }}=G_{i}-G_{o}=\Delta S-P+E-A-S_{i}+S_{o}
$$

where $G_{\text {net }}$ is positive when ground-water inflow exceeds ground-water outflow. Likewise, $G_{n e t}$ is negative when ground-water outflow exceeds ground-water inflow. Because net ground-water flow is computed as a residual to the rest of the budget, the net ground-water flow term $\left(G_{\text {net }}\right)$ incorporates all of the uncertainties in the other water-budget terms. Assuming that the errors in the other water-budget terms are independent, the uncertainty in $G_{n e t}$ (or the standard deviation around $\left.G_{\text {net }}\right)$ is the square root of the sum of the squared individual uncertainties (Winter, 1981):

$$
e G_{n e t}=\sqrt{e \Delta S^{2}+e P^{2}+e E^{2}+e A^{2}+e S_{i}^{2}+e S_{o}^{2}}
$$

where $e G_{\text {net }}$ is the uncertainty (standard deviation) in net ground-water flow. When net ground-water flow is small, the cumulative uncertainty in the other waterbudget terms can exceed the computed net groundwater flow.

Monthly water-budget terms, including monthly net ground-water flow $\left(G_{\text {net }}\right)$ and uncertainty $\left(e G_{\text {net }}\right)$ for Dosson Lake, Halfmoon Lake, and Round Lake, respectively, are listed in tables 3-5.

\section{Lake Storage}

Dosson Lake, Halfmoon Lake, and Round Lake were instrumented with water-level recorders that measured the lake level every 15 minutes to $\pm 0.01 \mathrm{ft}$ from June 1996 through May 1999 (fig. 21a). Bathymetric and lake-level data were used to calculate lake surface areas and volumes for the three lakes and these relations were used in the computation of the lake water budgets. When lake levels exceeded the range of bathymetric data, supplemental stage-area data were obtained from $1 \mathrm{ft}$ contour maps.

The average level of Dosson Lake was $52.19 \mathrm{ft}$ for the study period and levels ranged from $49.52 \mathrm{ft}$ (May 28-29, 1999) to $55.06 \mathrm{ft}$ (December 14, 1997).
The lake volume varied from $2,417,400$ to $4,905,050$ cubic feet $\left(\mathrm{ft}^{3}\right)$ or a volume change of approximately 51 percent for the 5.54-ft lake-level change (fig. 21b).

The average level of Halfmoon Lake was $42.36 \mathrm{ft}$ for the study period and levels ranged from $40.04 \mathrm{ft}$ (June 26, 1997) to $46.19 \mathrm{ft}$ (February 20-22, 1998). The lake volume ranged from $9,765,670$ to $19,603,370 \mathrm{ft}^{3}$ or a volume change of approximately 50 percent for the 6.15-ft lake-level change (fig. 21b).

The average level of Round Lake was $53.10 \mathrm{ft}$ for the study period and levels ranged from $51.47 \mathrm{ft}$ (July 7, 1998) to $55.83 \mathrm{ft}$ (February 21, 1998). The lake volume ranged from $3,000,730$ to $5,176,900 \mathrm{ft}^{3}$ or a volume change of approximately 42 percent for the 4.36-ft lake-level change. There was little deviation from the artificially maintained lake level of $53 \mathrm{ft}$ during the study, except during the El Niño period and when the augmentation well collapsed (fig. 21a).

\section{Rainfall}

Rainfall was measured at each lake and at the Section 21 well field climate station using storage and tipping-bucket rain gages (figs. 3, 4, and 5). The storage rain gages were considered more accurate than the tipping-bucket rain gages, which usually underestimated the daily rainfall totals. Observer readings were collected from storage rain gages on a biweekly basis and were used for the monthly rainfall totals. The 15-minute and daily totals from tipping gages were used to determine when the actual rainfall events occurred.

Storage rain gages were installed in December 1997 at each of the three lakes. Before December 1997, the monthly storage rainfall accumulations at the Section 21 well field climate station were used for Dosson Lake and Round Lake. An auxiliary rainfall site at Section 21 well field, maintained by SWFWMD, was used to supplement missing data at the climate station. The average rainfall from the Section 21 climate station and the Cosme-Odessa well field was used for Halfmoon Lake, until the storage rain gage was installed at the lake in December 1997. Cosme-Odessa well field is located 2 mi due west of Halfmoon Lake and Section 21 well field is approximately $2 \mathrm{mi}$ northeast of Halfmoon Lake. Uncertainties in monthly rainfall were higher when nearby auxiliary rain gages were used (10-15 percent), compared to when storage rain gages were used at the lake ( 5 percent). 
Table 3. Monthly water-budget terms, computed net ground-water flow, and estimated uncertainty or error associated with the computed net ground-water flow for Dosson Lake, June 1996 through May 1999

[Units in inches unless otherwise noted; $\Delta S$, change in lake storage; $P$, precipitation; $E$, evaporation; $S_{i}$, surface-water inflow; $S_{o}$, surface-water outflow; $G_{n e t}$, net ground-water flow (ground-water inflow minus outflow); $e G_{n e t}$, uncertainty or error in net ground-water flow; $A V S a$, average surface area in square feet, --, not determined. An asterisk $\left({ }^{*}\right)$ indicates the month or part of the month where the level of Dosson Lake was above 52.78 feet; during these periods, the combined Dosson-Sunshine Lake volume and surface area was used to estimate the water budget]

\begin{tabular}{|c|c|c|c|c|c|c|c|c|}
\hline Date & $\Delta S$ & $P$ & $E$ & $S_{i}$ & $S_{o}$ & $G_{n e t}$ & $e G_{n e t}$ & $A v S a$ \\
\hline \multicolumn{9}{|c|}{ Dosson Lake } \\
\hline Jun-96 & 3.9 & 7.5 & 6.2 & -- & $0.8^{*}$ & 3.4 & 1.5 & 881,444 \\
\hline Jul-96 & -1.6 & 3.7 & 6.0 & -- & $6.7 *$ & 7.3 & 3.6 & $1,170,237$ \\
\hline Aug-96 & -0.5 & 5.1 & 5.9 & -- & $0.1^{*}$ & 0.5 & 1.3 & $1,034,449$ \\
\hline Sep-96 & 0.6 & 6.5 & 5.1 & -- & $0.1^{*}$ & -0.6 & 1.2 & 986,513 \\
\hline Oct-96 & 0.2 & 3.5 & 4.2 & -- & $8.5^{*}$ & 9.5 & 4.3 & $1,168,776$ \\
\hline Nov-96 & -3.3 & 0.8 & 3.7 & -- & $0.1^{*}$ & -0.4 & 0.8 & 927,917 \\
\hline Dec-96 & -1.6 & 2.4 & 2.4 & -- & -- & -1.6 & 0.5 & 745,952 \\
\hline Jan-97 & -2.2 & 1.8 & 2.5 & -- & -- & -1.5 & 0.5 & 628,312 \\
\hline Feb-97 & -3.8 & 0.5 & 2.2 & -- & -- & -2.0 & 0.5 & 546,525 \\
\hline Mar-97 & -5.8 & 1.9 & 4.3 & -- & -- & -3.4 & 0.9 & 470,584 \\
\hline Apr-97 & 2.8 & 7.9 & 4.9 & -- & -- & -0.3 & 1.3 & 443,533 \\
\hline May-97 & -5.0 & 2.6 & 5.4 & -- & -- & -2.2 & 1.1 & 450,920 \\
\hline Jun-97 & -5.6 & 4.8 & 5.8 & -- & -- & -4.6 & 1.3 & 438,278 \\
\hline Jul-97 & 9.6 & 12.5 & 6.0 & -- & -- & 3.1 & 1.8 & 401,438 \\
\hline Aug-97 & 7.5 & 5.1 & 5.9 & -- & --- & 8.3 & 1.3 & 608,854 \\
\hline Sep-97 & 18.2 & 10.6 & 5.2 & 0.2 & $2.3^{*}$ & 14.9 & 2.1 & 598,242 \\
\hline Oct-97 & 8.8 & 8.1 & 4.6 & 0.7 & $11.6^{*}$ & 16.3 & 5.9 & $1,207,231$ \\
\hline Nov-97 & -2.6 & 4.2 & 2.8 & 16.0 & $45.3^{*}$ & 25.3 & 24.0 & $1,246,889$ \\
\hline Dec-97 & 4.9 & 16.9 & 2.4 & 22.2 & $51.4^{*}$ & 19.6 & 28.0 & $1,456,158$ \\
\hline Jan-98 & -5.8 & 5.8 & 1.7 & 16.6 & $46.5^{*}$ & 20.0 & 24.7 & $1,254,714$ \\
\hline Feb-98 & 0.9 & 11.0 & 2.5 & 17.2 & $43.5^{*}$ & 18.7 & 23.4 & $1,330,734$ \\
\hline Mar-98 & -5.8 & 6.8 & 3.9 & 13.3 & $39.1 *$ & 17.1 & 20.7 & $1,264,785$ \\
\hline Apr-98 & -7.1 & 0.1 & 4.7 & 0.4 & $6.2^{*}$ & 3.3 & 3.2 & $1,111,239$ \\
\hline May-98 & -6.9 & 1.5 & 5.2 & -- & -- & -3.2 & 1.1 & 684,249 \\
\hline Jun-98 & -10.7 & 1.2 & 6.6 & -- & -- & -5.3 & 1.4 & 481,859 \\
\hline Jul-98 & 12.3 & 12.5 & 5.9 & -- & -- & 5.7 & 1.5 & 578,158 \\
\hline Aug-98 & 6.0 & 7.7 & 5.9 & 1.1 & $13.6^{*}$ & 16.7 & 6.9 & $1,110,765$ \\
\hline Sep-98 & 9.6 & 15.6 & 5.2 & 17.6 & $43.6^{*}$ & 25.3 & 23.6 & $1,363,544$ \\
\hline Oct-98 & -13.3 & 0.2 & 4.4 & 4.1 & $18.0^{*}$ & 4.7 & 9.3 & $1,196,493$ \\
\hline Nov-98 & -2.3 & 1.2 & 3.3 & -- & $0.1^{*}$ & -0.2 & 0.7 & 954,098 \\
\hline Dec-98 & -2.4 & 1.6 & 2.4 & -- & -- & -1.7 & 0.5 & 726,099 \\
\hline Jan-99 & 0.3 & 3.2 & 2.1 & -- & -- & -0.7 & 0.5 & 659,001 \\
\hline Feb-99 & -4.4 & 0.2 & 2.4 & -- & -- & -2.2 & 0.5 & 595,714 \\
\hline Mar-99 & -5.6 & 1.3 & 4.1 & -- & -- & -2.9 & 0.9 & 492,487 \\
\hline Apr-99 & -9.6 & 1.0 & 4.8 & -- & -- & -5.7 & 1.1 & 446,462 \\
\hline May-99 & -7.2 & 3.9 & 5.3 & -- & -- & -5.7 & 1.1 & 432,419 \\
\hline \multicolumn{9}{|c|}{ Period of Record (June 1996 through May 1999) } \\
\hline Total & -18.2 & 181 & 156 & 109 & 337 & 185 & 181 & 835,974 \\
\hline $1996^{1}$ & -12.2 & 44.2 & 52.9 & 0.0 & 16.3 & 12.8 & 14.1 & 787,930 \\
\hline $1997^{2}$ & 5.4 & 87.3 & 50.7 & 86.5 & 246 & 128 & 131 & 966,901 \\
\hline $1998^{3}$ & -14.4 & 49.5 & 52.3 & 22.8 & 75.2 & 41.0 & 40.8 & 753,092 \\
\hline
\end{tabular}

${ }^{1}$ June 1, 1996 through May 31, 1997 (below average rainfall).

2 June 1, 1997 through May 31, 1998 (above average rainfall, El Niño year).

3 June 1, 1998 through May 31, 1999 (average rainfall). 
Table 4. Monthly water-budget terms, computed net ground-water flow, and estimated uncertainty or error associated with the computed net ground-water flow for Halfmoon Lake, June 1996 through May 1999

[Units in inches unless otherwise noted; $\Delta S$, change in lake storage; $P$, precipitation; $E$, evaporation; $S_{O}$, surfacewater outflow; $G_{n e t}$, net ground-water flow (ground-water inflow minus outflow); $e G_{n e t}$, uncertainty or error in net ground-water flow; $A v S a$, average surface area in square feet, --, not determined]

\begin{tabular}{|c|c|c|c|c|c|c|c|}
\hline Date & $\Delta S$ & $P$ & $\boldsymbol{E}$ & $S_{o}$ & $G_{\text {net }}$ & $e G_{n e t}$ & Av $S a$ \\
\hline \multicolumn{8}{|c|}{ Halfmoon Lake } \\
\hline Jun-96 & 2.9 & 9.1 & 6.2 & -- & 0.0 & 1.8 & $1,466,174$ \\
\hline Jul-96 & -2.5 & 4.9 & 6.0 & -- & -1.4 & 1.4 & $1,479,718$ \\
\hline Aug-96 & 3.5 & 6.7 & 5.9 & -- & 2.8 & 1.6 & $1,480,798$ \\
\hline Sep-96 & -0.5 & 5.8 & 5.1 & -- & -1.2 & 1.4 & $1,480,476$ \\
\hline Oct-96 & -1.8 & 2.6 & 4.2 & -- & -0.2 & 0.9 & $1,483,112$ \\
\hline Nov-96 & -5.5 & 1.0 & 3.7 & -- & -2.8 & 0.8 & $1,462,610$ \\
\hline Dec-96 & -0.4 & 2.9 & 2.4 & -- & -0.9 & 0.6 & $1,453,531$ \\
\hline Jan-97 & -2.7 & 2.0 & 2.5 & -- & -2.2 & 0.6 & $1,442,459$ \\
\hline Feb-97 & -3.7 & 0.7 & 2.2 & -- & -2.2 & 0.5 & $1,427,739$ \\
\hline Mar-97 & -5.1 & 1.7 & 4.3 & -- & -2.4 & 0.9 & $1,404,117$ \\
\hline Apr-97 & 1.5 & 8.2 & 4.9 & -- & -1.8 & 1.6 & $1,380,683$ \\
\hline May-97 & -4.1 & 1.6 & 5.4 & -- & -0.4 & 1.1 & $1,387,407$ \\
\hline Jun-97 & -5.6 & 5.3 & 5.8 & -- & -5.2 & 1.4 & $1,361,893$ \\
\hline Jul-97 & 12.6 & 12.2 & 6.0 & -- & 6.4 & 2.3 & $1,385,036$ \\
\hline Aug-97 & 0.6 & 4.4 & 5.9 & -- & 2.1 & 1.3 & $1,427,108$ \\
\hline Sep-97 & 7.9 & 11.2 & 5.2 & -- & 1.8 & 2.0 & $1,411,728$ \\
\hline Oct-97 & 5.6 & 6.6 & 4.6 & -- & 3.6 & 1.4 & $1,454,167$ \\
\hline Nov-97 & 4.4 & 4.2 & 2.8 & -- & 3.0 & 0.9 & $1,489,735$ \\
\hline Dec-97 & 30.9 & 15.9 & 2.4 & -- & 17.4 & 1.8 & $1,609,702$ \\
\hline Jan-98 & 5.3 & 4.8 & 1.7 & -- & 2.3 & 0.5 & $1,983,675$ \\
\hline Feb-98 & 0.9 & 11.2 & 2.5 & 8.4 & 0.5 & 4.3 & $2,150,375$ \\
\hline Mar-98 & -23.5 & 7.5 & 3.9 & 34.2 & 7.2 & 17.2 & $1,665,516$ \\
\hline Apr-98 & -7.5 & 0.1 & 4.7 & -- & -2.9 & 1.0 & $1,571,775$ \\
\hline May-98 & -8.5 & 1.1 & 5.2 & -- & -4.4 & 1.1 & $1,514,979$ \\
\hline Jun-98 & -9.6 & 0.8 & 6.6 & -- & -3.7 & 1.4 & $1,473,478$ \\
\hline Jul-98 & 14.0 & 13.7 & 5.9 & -- & 6.1 & 1.5 & $1,489,778$ \\
\hline Aug-98 & 4.5 & 7.5 & 5.9 & -- & 2.9 & 1.3 & $1,535,483$ \\
\hline Sep-98 & 4.7 & 13.9 & 5.2 & 13.2 & 9.1 & 6.7 & $1,562,399$ \\
\hline Oct-98 & -6.9 & 0.5 & 4.4 & 4.2 & 1.3 & 2.3 & $1,552,393$ \\
\hline Nov-98 & -4.2 & 1.2 & 3.3 & -- & -2.1 & 0.7 & $1,520,790$ \\
\hline Dec-98 & -3.8 & 1.6 & 2.4 & -- & -3.1 & 0.5 & $1,496,516$ \\
\hline Jan-99 & -0.1 & 3.3 & 2.1 & -- & -1.3 & 0.5 & $1,488,062$ \\
\hline Feb-99 & -5.4 & 0.3 & 2.4 & -- & -3.4 & 0.5 & $1,476,175$ \\
\hline Mar-99 & -4.9 & 1.5 & 4.1 & -- & -2.3 & 0.9 & $1,452,777$ \\
\hline Apr-99 & -7.7 & 0.9 & 4.8 & -- & -3.8 & 1.0 & $1,424,065$ \\
\hline May-99 & -5.2 & 3.9 & 5.3 & -- & -4.1 & 1.1 & $1,385,714$ \\
\hline \multicolumn{8}{|c|}{ Period of Record (June 1996 through May 1999) } \\
\hline Total & -18.0 & 181 & 156 & 60.0 & 17.1 & 46.9 & $1,506,448$ \\
\hline $1996^{1}$ & -18.1 & 47.2 & 52.9 & 0.0 & -12.4 & 12.8 & $1,445,735$ \\
\hline $1997^{2}$ & 22.1 & 84.5 & 50.7 & 42.6 & 30.9 & 25.1 & $1,585,474$ \\
\hline $1998^{3}$ & -24.2 & 49.0 & 52.3 & 17.4 & -3.5 & 13.9 & $1,488,136$ \\
\hline
\end{tabular}

${ }^{1}$ June 1, 1996 through May 31, 1997 (below average rainfall).

2 June 1, 1997 through May 31, 1998 (above average rainfall, El Niño year).

3 June 1, 1998 through May 31, 1999 (average rainfall). 
Table 5. Monthly water-budget terms, computed net ground-water flow, and estimated uncertainty or error associated with the computed net ground-water flow for Round Lake, June 1996 through May 1999

[Units in inches unless otherwise noted; $\Delta S$, change in lake storage; $P$, precipitation; $E$, evaporation; $S_{i}$, surface-water inflow; $A$, ground-water augmentation; $G_{\text {net }}$, net ground-water flow (ground-water inflow minus outflow); $e G_{n e t}$, uncertainty or error in net ground-water flow; $\mathrm{AV} S \mathrm{~S}$, average surface area in square feet, --, not determined]

\begin{tabular}{|c|c|c|c|c|c|c|c|c|}
\hline Date & $\Delta S$ & $P$ & $\boldsymbol{E}$ & $S_{i}$ & $\boldsymbol{A}$ & $G_{\text {net }}$ & $e G_{n e t}$ & $A v S a$ \\
\hline \multicolumn{9}{|c|}{ Round Lake } \\
\hline Jun-96 & 0.6 & 7.5 & 6.2 & -- & 14.9 & -15.7 & 1.6 & 474,942 \\
\hline Jul-96 & -3.2 & 3.7 & 6.0 & -- & 15.5 & -16.4 & 1.5 & 473,102 \\
\hline Aug-96 & -0.2 & 5.1 & 5.9 & -- & 19.8 & -19.2 & 1.6 & 470,607 \\
\hline Sep-96 & -0.1 & 6.5 & 5.1 & -- & 18.7 & -20.2 & 1.5 & 467,688 \\
\hline Oct-96 & 2.4 & 3.5 & 4.2 & -- & 18.4 & -15.3 & 1.3 & 472,840 \\
\hline Nov-96 & -3.1 & 0.8 & 3.7 & -- & 18.3 & -18.5 & 1.2 & 470,745 \\
\hline Dec-96 & -0.1 & 2.4 & 2.4 & -- & 19.9 & -20.0 & 1.1 & 468,821 \\
\hline Jan-97 & -0.8 & 1.8 & 2.5 & -- & 19.1 & -19.2 & 1.1 & 466,792 \\
\hline Feb-97 & -1.9 & 0.5 & 2.2 & -- & 18.0 & -18.2 & 1.0 & 465,147 \\
\hline Mar-97 & -3.3 & 1.9 & 4.3 & -- & 20.0 & -20.9 & 1.3 & 459,515 \\
\hline Apr-97 & 8.1 & 7.9 & 4.9 & -- & 24.5 & -19.5 & 1.8 & 459,051 \\
\hline May-97 & 1.7 & 2.6 & 5.4 & -- & 26.3 & -21.8 & 1.7 & 472,397 \\
\hline Jun-97 & 1.8 & 4.8 & 5.8 & -- & 26.2 & -23.5 & 1.8 & 474,265 \\
\hline Jul-97 & 1.1 & 12.5 & 6.0 & -- & 15.3 & -20.7 & 1.9 & 478,104 \\
\hline Aug-97 & -2.8 & 5.1 & 5.9 & -- & 18.8 & -20.7 & 1.6 & 476,784 \\
\hline Sep-97 & 7.8 & 10.6 & 5.2 & -- & 20.9 & -18.6 & 1.9 & 475,950 \\
\hline Oct-97 & -1.1 & 8.1 & 4.6 & -- & 10.7 & -15.2 & 1.3 & 479,622 \\
\hline Nov-97 & -5.5 & 4.2 & 2.8 & -- & 3.0 & -9.9 & 0.8 & 480,095 \\
\hline Dec-97 & 29.5 & 17.1 & 2.4 & 11.4 & 0.0 & 3.4 & 6.0 & 496,263 \\
\hline Jan-98 & -4.0 & 5.5 & 1.7 & -- & 0.0 & -7.7 & 0.5 & 556,203 \\
\hline Feb-98 & 6.0 & 12.4 & 2.5 & -- & 0.0 & -4.0 & 0.8 & 561,419 \\
\hline Mar-98 & -6.7 & 6.8 & 3.9 & -- & 0.0 & -9.6 & 0.9 & 549,325 \\
\hline Apr-98 & -12.7 & 0.1 & 4.7 & -- & 0.0 & -8.1 & 1.6 & 517,493 \\
\hline May-98 & -7.0 & 1.7 & 5.2 & -- & 11.7 & -15.1 & 1.4 & 478,756 \\
\hline Jun-98 & -19.5 & 2.4 & 6.6 & -- & 1.3 & -16.6 & 2.4 & 465,832 \\
\hline Jul-98 & -1.7 & 11.6 & 5.9 & -- & 0.0 & -7.4 & 1.3 & 447,660 \\
\hline Aug-98 & 17.9 & 9.2 & 5.9 & -- & 21.4 & -6.8 & 1.9 & 464,138 \\
\hline Sep-98 & 7.4 & 15.3 & 5.2 & -- & 1.4 & -4.2 & 1.3 & 482,598 \\
\hline Oct-98 & -9.3 & 0.2 & 4.4 & -- & 3.3 & -8.3 & 1.0 & 482,643 \\
\hline Nov-98 & -2.3 & 1.1 & 3.3 & -- & 13.0 & -13.1 & 0.9 & 475,300 \\
\hline Dec-98 & -0.8 & 1.8 & 2.4 & -- & 14.7 & -15.0 & 0.9 & 472,354 \\
\hline Jan-99 & 1.5 & 3.1 & 2.1 & -- & 15.4 & -14.8 & 0.9 & 471,854 \\
\hline Feb-99 & 0.2 & 0.2 & 2.4 & -- & 17.4 & -15.0 & 1.0 & 471,424 \\
\hline Mar-99 & 1.2 & 1.2 & 4.1 & -- & 25.4 & -21.3 & 1.5 & 472,629 \\
\hline Apr-99 & -8.0 & 1.1 & 4.8 & -- & 12.7 & -17.0 & 1.2 & 462,847 \\
\hline May-99 & -1.4 & 3.1 & 5.3 & -- & 30.3 & -29.5 & 1.9 & 464,500 \\
\hline \multicolumn{9}{|c|}{ Period of Record (June 1996 through May 1999) } \\
\hline Total & -8.8 & 183 & 156 & 11.4 & 496 & -544 & 42.5 & 479,992 \\
\hline $1996^{1}$ & -0.2 & 44.2 & 52.9 & 0.0 & 233 & -225 & 16.4 & 468,471 \\
\hline $1997^{2}$ & 5.5 & 88.7 & 50.7 & 11.4 & 107 & -151 & 14.4 & 502,023 \\
\hline $1998^{3}$ & -14.6 & 50.2 & 52.3 & 0.0 & 156 & -169 & 13.3 & 469,481 \\
\hline
\end{tabular}

${ }^{1}$ June 1, 1996 through May 31, 1997 (below average rainfall).

2 June 1, 1997 through May 31, 1998 (above average rainfall, El Niño year).

${ }^{3}$ June 1, 1998 through May 31, 1999 (average rainfall). 

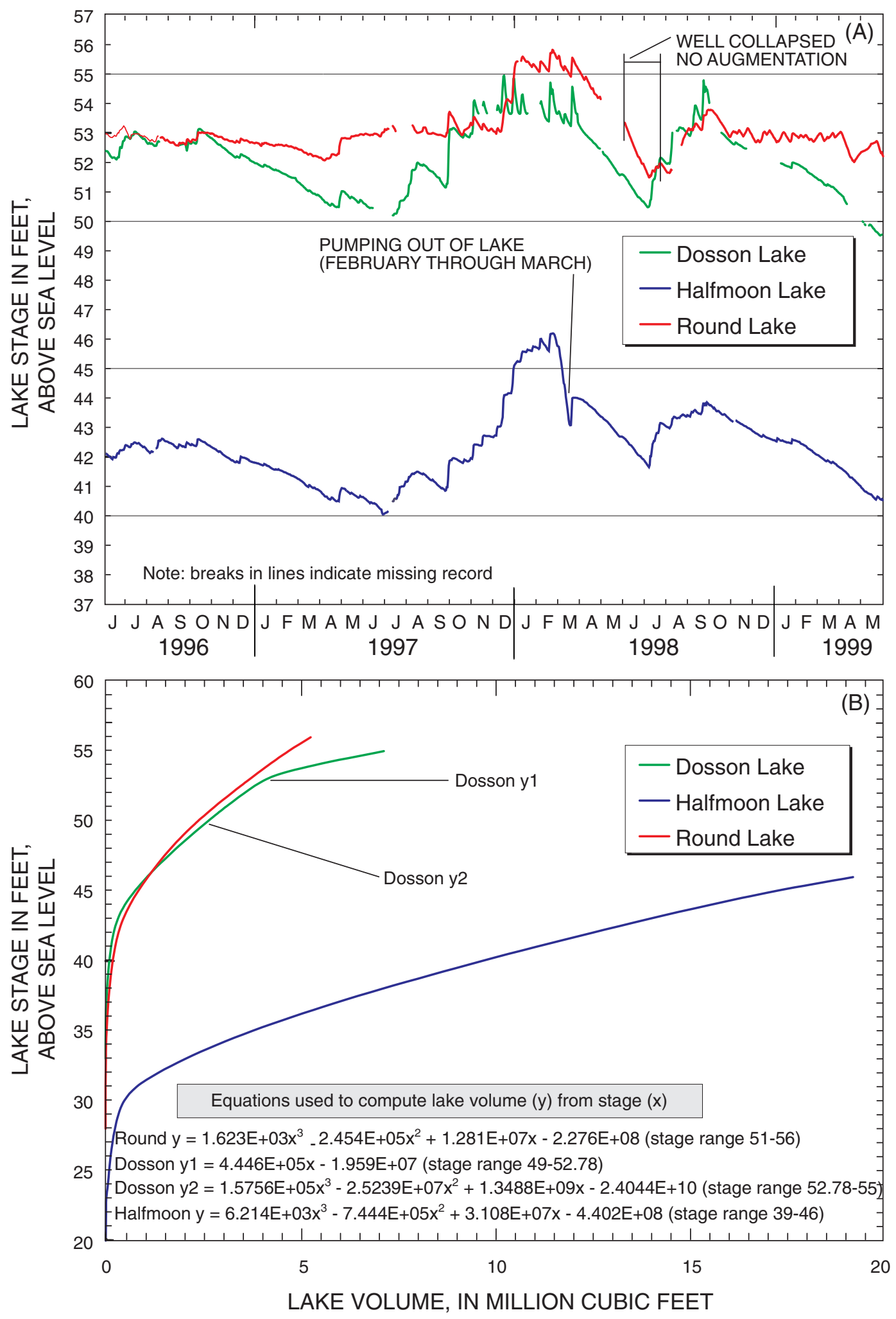

Figure 21. (A) Lake hydrographs and (B) stage-volume relation curves for Dosson Lake, Halfmoon Lake, and Round Lake. 
Total rainfall for the 3-year data-collection period was 183.6 inches (in.) at the Section 21 climate station; monthly rainfall is shown in figure 22 . Monthly rainfall at Section 21 well field varied from 0.1 in. in April 1998 to 18.0 in. in December 1997. The rainfall varied seasonally with most of the rainfall occurring during the summer months except for the high rainfall associated with the El Niño period. The highest daily rainfall amount for the 3-year data-collection period was 5.08 in. on September 27, 1997. Annual rainfall totals at the climate station were 44.2, 90.8, and 48.6 in. for June 1996 through May 1997, June 1997 through May 1998, and June 1998 through May 1999, respectively. The annual rainfall totals at the three lakes were within 7 percent of each other (tables 3-5).

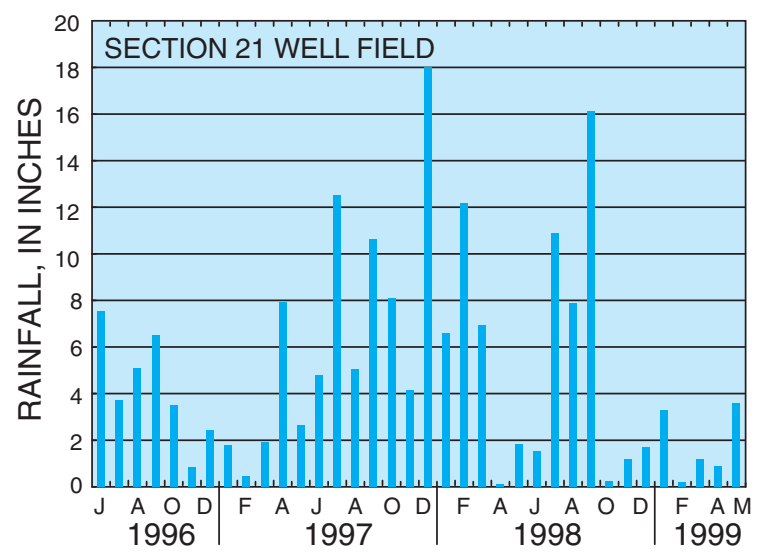

Figure 22. Monthly rainfall at Section 21 well field climate station, June 1996 through May 1999.

\section{Evaporation}

Two data approaches were used to determine the monthly lake evaporation rates at the study lakes. These approaches included the use of pan evaporation data from Section 21 well field and energy-budget data from Lake Starr, located approximately $60 \mathrm{mi}$ to the east. Large discrepancies were noted between the two lake evaporation estimates. Because the energy-budget method is considered to be the most accurate method for measuring evaporation from lakes for periods of a week or longer (Winter, 1981), the energy-budget lake evaporation rates were used in the water-budget calculations for the study lakes. The effects of using the pan evaporation data on the net ground-water flow calculations are discussed in a later section.
At Section 21 well field (Lake Park), a National Weather Service class-A pan was used to measure pan evaporation. Pan water levels, rainfall, windspeed, pan and air temperature, relative humidity, and barometric pressure were measured every 15-minutes. Lake evaporation was then estimated by multiplying the measured pan evaporation by a pan coefficient. The ratio of annual evaporation from a shallow lake to that from a pan (pan coefficient) is estimated at 0.74 in central Florida (Farnsworth and others, 1982). Recent studies of lakes in central Florida by Sacks and others (1994), Lee and Swancar (1997), and Swancar and others (2000) report annual pan coefficients ranging from 0.62 to 0.89 .

Lake evaporation at Section 21 well field for August 1996 through July 1997 was 33 in/yr using an annual pan coefficient of 0.74 . Another pan evaporation site located 5 mi north of Section 21 well field (Lake Como) had a lake evaporation rate of $37 \mathrm{in} / \mathrm{yr}$ during the same period using a pan coefficient of 0.74 . These annual rates were considered low, because published estimates of annual lake evaporation in the Tampa area average 50 in. (Kohler and others, 1959). Large differences were also noted between these pan evaporation rates and the energy-budget evaporation rate at Lake Starr (57 in/yr for the same time period; Swancar and others, 2000). Uncertainty in the pan evaporation data is possibly related to the pan operation or local micro-climatic conditions surrounding the pan, which results in unreliable data (Allen and others, 1998). Therefore, the energy-budget evaporation data from Lake Starr was used, but modified to reflect temperature differences in the study area.

Differences in coastal and inland air temperatures were considered when using the Lake Starr energy-budget data (Nixon and Lawless, 1968). Two inland weather sites (Lake Starr and Lakeland National Oceanic and Atmospheric Administration weather station) had average temperatures of 0.6 and 2.4 degrees Fahrenheit $\left({ }^{\circ} \mathrm{F}\right)$ higher than Section 21 climate station for a 2-year comparison period. An evapotranspiration equation developed by Jenson (1974) was used to adjust evaporation rates at Lake Starr based on temperature differences. Equations developed for potential evapotranspiration from vegetation are commonly used to determine evaporation from open water (Winter and Rosenberry, 1995). The Jensen-Haise equation is: 


$$
P E T=\left(6.73 \times 10^{-4}\right)\left(0.014 T_{a}-0.50\right)\left(Q_{S}\right)(2.54),
$$

where $P E T$ in inches per month $(\mathrm{in} / \mathrm{mo})$ is evaporation or potential evapotranspiration, $T_{a}$ is air temperature at Lake Starr, in ${ }^{\circ} \mathrm{F}$, and $Q_{S}$ is solar radiation at Lake Starr (in calories per square centimeter per day). A temperature decrease of $1.5^{\circ} \mathrm{F}$ was used based on the average temperature difference between Section 21 climate station temperature and the two inland weather sites. Based on the potential evapotranspiration equation, lowering the average temperature by $1.5^{\circ} \mathrm{F}$ lowered the monthly Lake Starr energy-budget evaporation rates by 8 percent. Therefore, an 8 percent reduction in Lake Starr evaporation rates was used in water-budget calculations. For periods when monthly energy budget data was not available, the 2-yr monthly average of Lake Starr data was used in water-budget calculations.

Total evaporation for the 3-year data-collection period was 156 in., using the reduced evaporation rates derived at Lake Starr. Annual evaporation totals were 52.9, 50.7, and 52.3 in. for June 1996 through May 1997, June 1997 through May 1998, and June 1998 through May 1999, respectively. Monthly evaporation rates had a seasonal trend with the highest rate in June 1998 (6.6 in/mo) and lowest in January 1998 (1.7 in/mo) (tables 3-5).

\section{Augmentation}

Augmentation water from the Upper Floridan aquifer is pumped into Round Lake when the lake level falls below an elevation of approximately $53 \mathrm{ft}$ above sea level. A saddle-type flowmeter totals the amount of discharge from the well, and pumpage volumes were recorded on a biweekly basis. The total augmentation at Round Lake for the 3-year study period was approximately $146 \mathrm{Mgal}$ (equivalent to $496 \mathrm{in}$. over the lake surface area, table 5). This volume is enough to fill the lake approximately 5.6 times. Annual augmentation rates were $68.1 \mathrm{Mgal}$ (233 in.), $31.7 \mathrm{Mgal}$ (107 in.), and 45.7 Mgal (156 in.) for June 1996 through May 1997, June 1997 through May 1998, and June 1998 through May 1999, respectively. Figure 23a shows the monthly augmentation rates for June 1996 through May 1999. The average monthly ground-water augmentation rate for the study period was $4.1 \mathrm{Mgal}$ per month $\left(553,819\right.$ cubic feet per month $\left(\mathrm{ft}^{3} / \mathrm{mo}\right)$ or $13.8 \mathrm{in} / \mathrm{mo}$ ). The monthly augmentation rates ranged from 0 gallons when the lake was not augmented, to
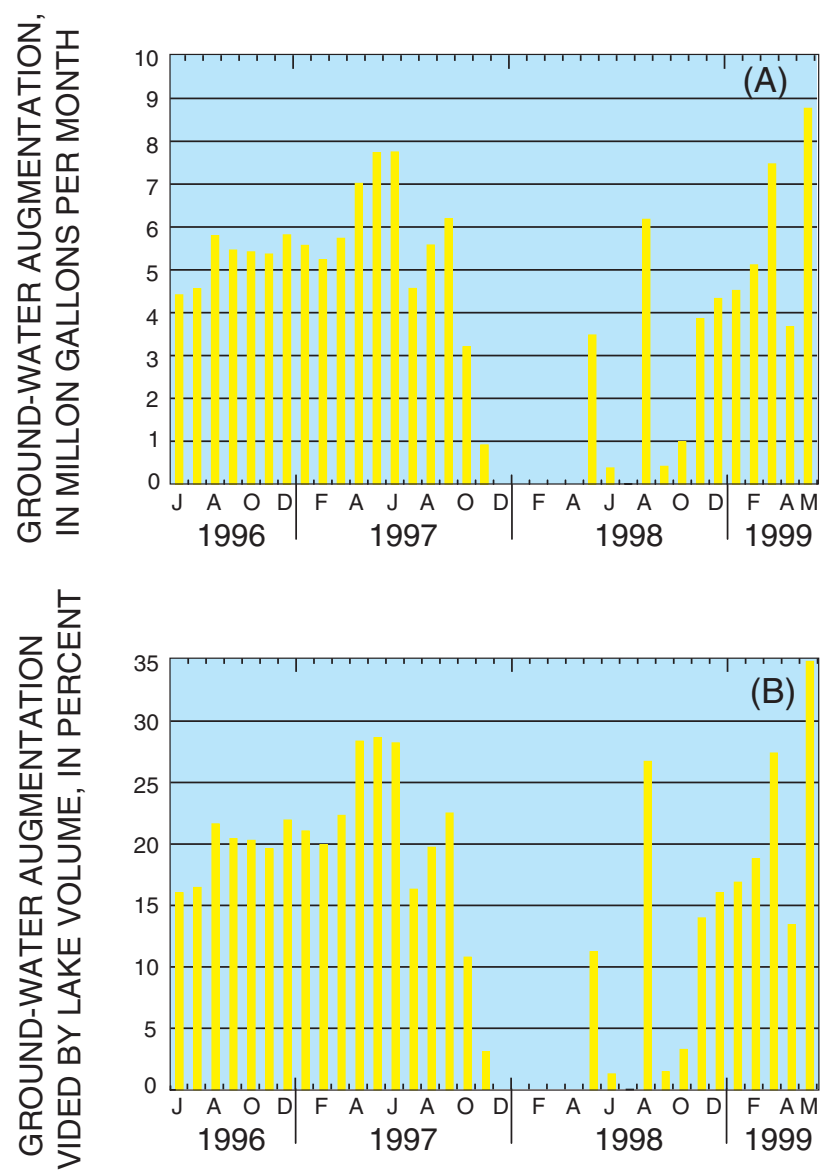

Figure 23. (A) Monthly ground-water augmentation rates and (B) monthly percentage of ground-water augmentation in relation to the lake volume for Round Lake, June 1996 through May 1999.

$8.8 \mathrm{Mgal}$ per month $\left(1,172,086 \mathrm{ft}^{3} / \mathrm{mo}\right.$ or $\left.30.3 \mathrm{in} / \mathrm{mo}\right)$ in May 1999. The lake was not augmented from January through April 1998, due to high lake levels from the El Niño rainfall events, and from June 11 through July 31, 1998, when the augmentation well collapsed. A new well was drilled during this time and augmentation resumed in August 1998. Well construction information for the old and new augmentation well is listed in appendix A as index number 26 and 133, respectively.

The monthly augmentation volume can be expressed as a percentage of total lake volume for each month of the study. The month's augmentation volume ranged from 0 percent of the total lake volume in January 1998 through April 1998 and July 1998 to 35 percent in May 1999 (fig. 23b). The average monthly percentage of augmentation water to lakewater volume was 16 percent for the study period. 


\section{Surface-Water Inflows and Outflows}

All three lakes had some surface-water inflow or outflow during the study, predominately during the high rainfall events of El Niño (tables 3-5). Storm-water runoff into the three lakes was considered negligible because of the relatively flat topography and the permeable surficial sand in the basins. Drainage ditches and grassy swales located along the residential streets retain most of the surface-water runoff from nearby roadways. The surface-water flows of the three lakes are summarized in the following sections.

\section{Dosson Lake}

Dosson Lake had the most surface-water inflows and outflows of the study lakes. The higher surfacewater flows can be attributed to the drainage patterns and land use surrounding Dosson Lake. The undeveloped wetlands to the north and south of Dosson Lake are relatively flat and swampy, and the natural drainage patterns have not been significantly altered for residental development as they have been at Halfmoon Lake and Round Lake. During high rainfall periods, surface water originating in the wetlands to the north of Dosson Lake flows south through several undefined channels and eventually reaches the lake. A shallow, poorly maintained drainage ditch in the wetlands to the south of Dosson Lake carries surface-water flow to Sunshine Lake (fig. 3). Surface water flows southeast out of Sunshine Lake through a concrete control structure and continues in a southeasterly direction through a series of wetlands, eventually reaching Brushy Creek.

The surface-water flow patterns at Dosson Lake were dependent on the lake levels of Lake Darby and Sunshine Lake. When the lake level was below $52.30 \mathrm{ft}$ above sea level, there were no surface-water inflows or outflows at Dosson Lake and each of the surrounding lakes were independent of one another. When the lake level at Dosson Lake was between 52.30 and $52.78 \mathrm{ft}$ above sea level, water from Dosson Lake flowed south into Sunshine Lake through the shallow drainage ditch and spilled over into the adjacent, low-lying wetlands (fig. 3). During these periods, the surface-water outflow (discharge) rate to Sunshine Lake was calculated using the Manning equation (Chow, 1959) as follows:

$$
Q=\frac{1.486}{n} A R^{2 / 3} S_{f}^{1 / 2}
$$

where $Q$ is discharge, in cubic feet per second; $n$ is the roughness coefficient, dimensionless; $A$ is the crosssectional area, in square feet; $R$ is the hydraulic radius, in feet; and $S_{f}$ is the friction slope, in foot per foot. The variables $A$ and $R$ were estimated based on channel geometry and the topography in the wetlands; $n$ was estimated based on values from Gillen (1996); and $S_{f}$ was estimated from the difference in stage and the lateral distance between Sunshine Lake and Dosson Lake.

When Dosson Lake exceeded a level $52.78 \mathrm{ft}$ above sea level, outflow from Sunshine Lake occurred, and the Sunshine Lake outlet became the dominant hydraulic control for outflow at Dosson Lake. As a result, Dosson Lake and Sunshine Lake became a single water body above the $52.78 \mathrm{ft}$ level, and the combined lake volume and surface area were used to estimate outflow and the water budget for Dosson Lake. The friction slope $\left(S_{f}\right)$ for the connected lakes was computed using data from a discharge measurement made at the Sunshine Lake outflow on March 9, 1998, when the stage of the connected lakes was $53.64 \mathrm{ft}$ above sea level. Periodic surface-water outflows at Dosson Lake ranged from 6,100 $\mathrm{ft}^{3}(0.1 \mathrm{in} / \mathrm{mo})$ during August 1996, September 1996, November 1996, and November 1998, to $6,240,000 \mathrm{ft}^{3}(51.4 \mathrm{in} / \mathrm{mo})$ during December 1997 (table 3).

When the level of Lake Darby exceeded $53 \mathrm{ft}$ above sea level, the lake flooded the wetlands to the north of Dosson Lake, and this water eventually flowed into Dosson Lake through a series of undefined channels. These surface-water inflows into Dosson Lake were dependent on the levels of Lake Darby and were computed using the Manning equation (eq. 5). Periodic surface-water inflow to Dosson Lake ranged from $11,000 \mathrm{ft}^{3}(0.2 \mathrm{in} / \mathrm{mo})$ during September 1997 to 2,694,000 $\mathrm{ft}^{3}$ (22.2 in/mo) during December 1997 (table 3).

\section{Halfmoon Lake}

There are no surface-water inflow sources to Halfmoon Lake, but water was pumped out of Halfmoon Lake between February and March 1998 to alleviate flooding conditions during the El Niño period. Pumping records from the Hillsborough County stormwater office, the lake hydrograph, and stage-volume relations were used to quantify the pumpage from the lake. Based on these analyses, approximately $6,248,300 \mathrm{ft}^{3}$ (42.6 in.) of water was pumped out of Halfmoon Lake. 
A high-water weir outlet was installed on the northwestern side of the lake in June 1998 in response to the El Niño flooding (fig. 4). This outlet carries overflow from Halfmoon Lake to Rocky Creek through a drainage canal when the lake level rises above $43.45 \mathrm{ft}$ above sea level. Surface-water outflow occurred during September and October 1998 because of high rainfall during September 1998. The surface-water outflow during this time was computed using the broad-crested weir flow equation (Brater and King, 1976) (eq. 6):

$$
Q=C L H^{3 / 2},
$$

where $Q$ is weir discharge, in cubic feet per second $\left(\mathrm{ft}^{3} / \mathrm{s}\right) ; C$ is the weir coefficient (2.695 to 2.715); $L$ is the length of weir; and $H^{3 / 2}$ is head, height of the lake level above weir elevation of 43.47, in feet. Approximately 2,258,000 $\mathrm{ft}^{3}$ (17.4 in.) of lake water was removed by the outflow structure during September and October 1998 (table 4).

\section{Round Lake}

There is no surface-water outlet for Round Lake, but during very high water levels, surface water enters Round Lake from a drainage ditch at the northeast end of the lake (fig 5). This canal carries overflow from Saddleback Lake to Round Lake when the level of Saddleback Lake rises above $54.94 \mathrm{ft}$ above sea level. Although this level is seldom reached, overflow occurred from Saddleback Lake to Round Lake during the high rainfall events of El Niño (December 16-27, 1997). This overflow was computed based on the cross-sectional area of the drainage ditch and an estimated flow velocity of 0.7 feet per second (ft/s). This velocity was estimated based on a similar flow measurement made at Dosson Lake. Based on this computation, approximately $470,000 \mathrm{ft}^{3}(11.4 \mathrm{in} / \mathrm{mo})$ of surface-water inflow occurred during December 1997 from Saddleback Lake to Round Lake (table 5).

\section{Net Ground-Water Flow}

Net ground-water flow results provide insight into the differences in ground-water exchange between the augmented lake (Round Lake) and the non-augmented lakes (Dosson Lake and Halfmoon Lake) (fig. 24a-c; tables 3-5). The 3-year data-collection period (June 1996 through May 1999) encompassed a wide range in weather conditions including a below average, an extremely high, and an average rainfall year. These weather conditions helped characterize the localized ground-water responses at each lake basin. When the uncertainty or error ( $\left.e G_{n e t}\right)$ was greater than or equal to the monthly net ground-water flow rate $\left(G_{n e t}\right)$, that flow rate was not considered in the following monthly net ground-water flow section (tables 3-5).

\section{Monthly Net Ground-Water Flow}

Net ground-water inflow to Dosson Lake occurred in 12 of the 36 months (33 percent) of the data-collection period (fig. 24a; table 3). Most of the net ground-water inflow at Dosson Lake occurred during the rainy summer months and during the El Niño period (October 1997 through March 1998). Dosson Lake had the highest magnitude of net ground-water inflow for the study lakes. These high ground-water inflow rates may be related to ground-water inflow from the adjacent wetlands during and following high recharge. Even though the uncertainty or error in net ground-water flow increased during the occurrence of surface-water flows, the net ground-water flow rates provided a valuable insight into ground-water/lake interactions during these high recharge periods. Net ground-water outflow at Dosson Lake occurred in 14 of 36 months, or 39 percent, of the data-collection period (table 3). Net ground-water outflow generally occurred during the low recharge periods of the winter and spring months.

Net ground-water inflow occurred in fewer months at Halfmoon Lake than at Dosson Lake (10 of 36 months, or 28 percent, of the data-collection period) (fig. 24b; table 4). Net ground-water inflow at Halfmoon Lake also occurred during the summer months and during the El Niño period, but the magnitude of net ground-water inflow was typically lower than at Dosson Lake. Net ground-water outflow occurred more often at Halfmoon Lake than at Dosson Lake (17 of 36 months, or 47 percent, of the data-collection period). When net ground-water outflow occurred at both Halfmoon Lake and Dosson Lake, the magnitude (in inches) was very similar for 11 of 13 months.

In contrast to the non-augmented lakes, net ground-water outflow dominated the water budget at Round Lake (35 of 36 months) (fig. 24c; table 5). Monthly net ground-water outflow at Round Lake was an average of 8 times greater than monthly net ground-water outflow at Dosson and Halfmoon Lakes. 

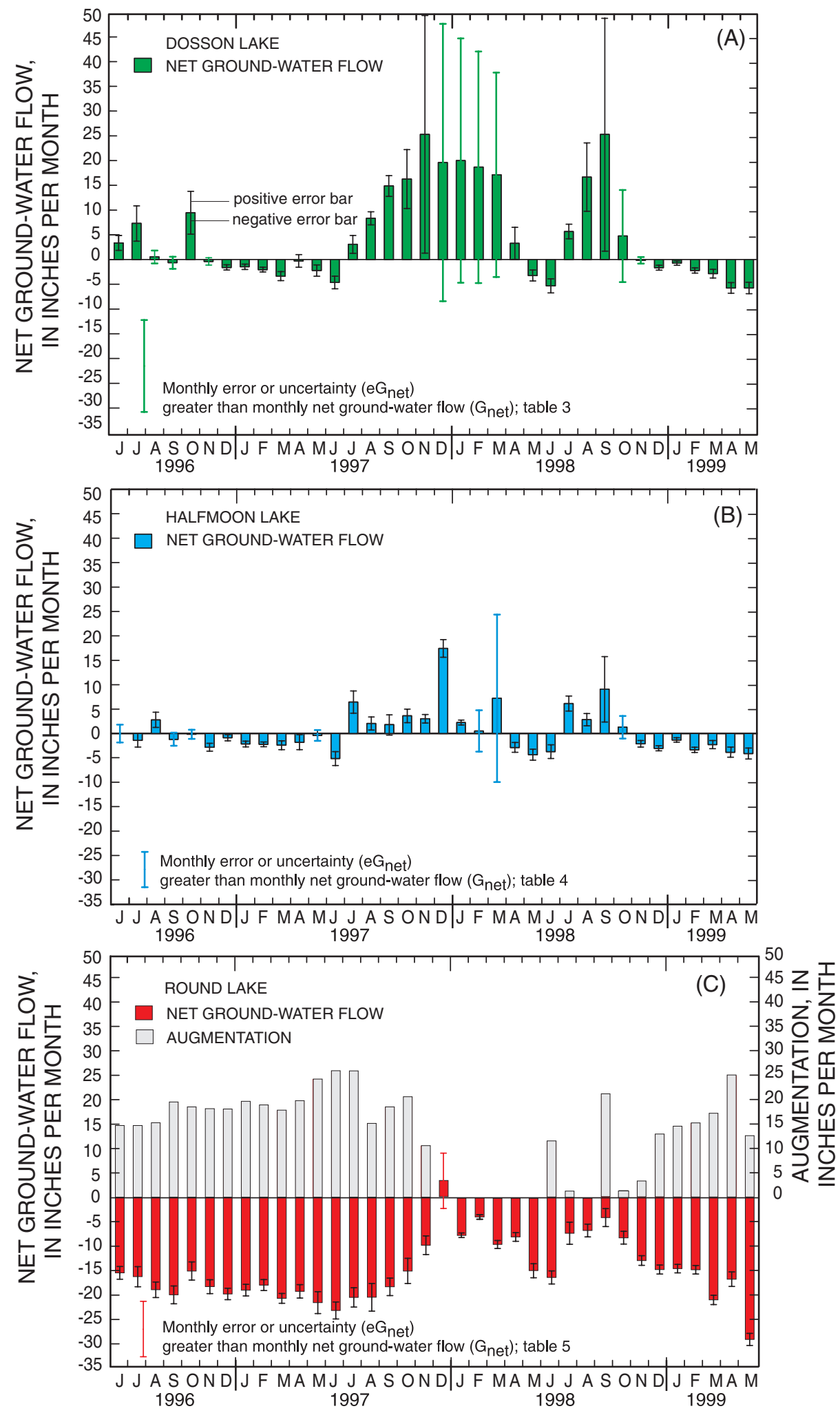

Figure 24. Seasonal variability of net ground-water flow for (A) Dosson Lake, (B) Halfmoon Lake, and (C) Round Lake, June 1996 through May 1999. 
Net ground-water outflow exceeded inflow from augmentation during 17 of 36 months, or 47 percent, of the data-collection period (fig. 24c; table 5). Local groundwater pumping, augmentation, and hydrogeologic factors are responsible for the higher net ground-water outflow at Round Lake. As a result of localized ground-water pumping, the head difference between the lake and the Upper Floridan aquifer increases, which increases lake leakage and results in lowered lake levels. Augmenting the lake further increases the head difference between the lake, the water table, and the Upper Floridan aquifer, which results in an increase in lateral and vertical outflow from the lake. The lack of confinement or breaches in the intermediate confining unit facilitates the downward movement of this augmented lake water back into the Upper Floridan aquifer.

\section{Variables Influencing Net Ground-Water Flow}

Relations between monthly net ground-water flow and a number of external hydrologic variables were examined to determine what influences net groundwater flow at the three lakes (table 6). The variables include: lateral head gradient between the lake and the water-table, vertical head difference between the lake and the Upper Floridan aquifer, monthly rainfall, percent of the lake perimeter that potentially receives groundwater inflow, and augmentation rate (for Round Lake). The strengths of the linear relations ( $\mathrm{r}^{2}$ values) and graphical analysis were used to determine which hydrologic variables most influenced the magnitude and direction of monthly net ground-water flow at the three lakes. The basic hydraulic principal of Darcy's Law was explored in these analyses, in which net ground-water flow is correlated to the hydraulic gradient in the aquifers around the lake and the lake bed area through which ground-water flow occurs. All regressions presented are significant to an alpha level ( $\alpha$ level) of 0.05 .

A strong linear correlation between monthly net ground-water flow and monthly average lateral head gradient was observed for all three lakes. This strong correlation indicates that lateral flow within the surficial aquifer had a significant effect on net ground-water flow at the lakes (table 6). The linear relations for Dosson Lake improved when monthly data were subdivided into two groups based on surface-water inflow conditions (table 6). These improved linear relations illustrate how the lake level is more "flashy" when surface-water inflow occurs, which affects the lateral head gradient.
Table 6. Summary of relations between monthly net ground-water flow and selected hydraulic variables

$\left[\mathrm{r}^{2}\right.$, coefficient of determination between monthly net ground-water flow and hydraulic variables; all regressions significant to alpha level of 0.05 ; --, not applicable]

\begin{tabular}{lccc}
\multicolumn{1}{c}{ Hydraulic variables } & $\begin{array}{c}\text { Dosson } \\
\text { Lake } \\
\mathbf{r}^{2}\end{array}$ & $\begin{array}{c}\text { Halfmoon } \\
\text { Lake } \\
\mathbf{r}^{2}\end{array}$ & $\begin{array}{c}\text { Round } \\
\text { Lake } \\
\mathbf{r}^{2}\end{array}$ \\
$\begin{array}{l}\text { Monthly head difference } \\
\text { between the lake and the } \\
\text { surficial aquifer }\end{array}$ & $\begin{array}{c}20.84 \\
{ }^{1} 0.75\end{array}$ & 0.82 & 0.79 \\
$\begin{array}{l}\text { Monthly head difference } \\
\text { between the lake and the }\end{array}$ & 0.34 & 0.30 & 0.72 \\
$\begin{array}{l}\text { Upper Floridan aquifer } \\
\text { Monthly rainfall }\end{array}$ & 0.41 & 0.62 & 0.24 \\
$\begin{array}{l}\text { Mercentage of lake } \\
\text { perimeter that receives } \\
\text { ground-water inflow }\end{array}$ & 0.67 & 0.41 & 0.64 \\
\begin{tabular}{l} 
Augmentation \\
\hline
\end{tabular} & -- & - & \\
\hline
\end{tabular}

${ }^{1}$ Monthly head differences were the average of continuous recorded daily water-level data for DL3 well (index number 75) at Dosson Lake and HML60 well (index number 69) at Halfmoon Lake; and monthly head differences were the average of weekly water-level measurements at Berger Shallow well (index number 30).

${ }^{2}$ For months without surface-water inflow.

${ }^{3}$ For months with surface-water inflow.

${ }^{4}$ Monthly head differences were the average of continuously recorded daily water-level data for DL1 well (index number 73) at Dosson Lake, HML59 well (index number 68) at Halfmoon Lake, and Berger Deep well (index number 29).

Round Lake had the best correlation of the study lakes between monthly net ground-water flow and the monthly average head difference between the lake and the Upper Floridan aquifer $\left(r^{2}=0.72\right.$; table 6$)$. This correlation illustrates the importance that the heads in Upper Floridan aquifer have on ground-water outflow at Round Lake. As the vertical head difference increases between the lake and the Upper Floridan aquifer, more ground-water outflow occurs. This correlation was less significant for Dosson Lake and Halfmoon Lake (table 6), and is probably related to the greater importance of ground-water inflow in the net ground-water flow term than at Round Lake. This relation also indicates that there is more confinement between the surficial aquifer and Upper Floridan aquifer at the two nonaugmented lakes, which limits vertical ground-water outflow. 
The relation between monthly net ground-water flow and monthly rainfall differed at the three lakes. Halfmoon Lake had the best correlation between monthly rainfall and net ground-water flow (table 6). This correlation may indicate that the ground-water flow system at Halfmoon Lake responds more rapidly to recharge events. Dosson Lake had a less significant correlation between net ground-water flow and monthly rainfall than Halfmoon Lake (table 6), which may be because of a slower release of water from storage in the wetlands adjacent to the lake following rainfall events. Round Lake had the least significant correlation between net ground-water flow and monthly rainfall because net ground-water flow at Round Lake is dominated by ground-water outflow (table 6). Rainfall primarily affects ground-water inflow, which is less important in the water budget of Round Lake.

Monthly net ground-water flow was significantly correlated to the percentage of the lake perimeter receiving ground-water inflow at each lake (table 6). Using monthly water-table maps, the percentage of the lake perimeter receiving ground-water inflow was approximated where the water table was higher than the lake level (fig. 25). As water levels increase in the surficial aquifer due to recharge, the part of the lake perimeter receiving ground-water inflow increases, which increases the magnitude of ground-water inflow to the lake. Increases in the inflow perimeter are likely the result of ground-water flow reversals, which temporarily cause ground-water inflow to occur along part of a lake perimeter that typically flows out. Ground-water flow reversals were documented all around Dosson Lake and on the west and south sides of Halfmoon Lake. At Round Lake, ground-water outflow occurred around the entire lake perimeter for much of the study. However, the water table was higher than the lake level along the eastern perimeter between October 1997 and November 1998 (fig. 25). The significant correlation between net ground-water flow and the percentage of the lake perimeter receiving ground-water inflow $\left(r^{2}=0.64\right)$ suggests that the lake received groundwater inflow during wet periods of the study, even though net ground-water outflow predominated.

A significant linear correlation existed between the monthly augmentation rate at Round Lake and the monthly net ground-water flow $\left(r^{2}=0.69\right.$; table 6$)$. The linear correlations improved with time when both net ground-water flow and monthly augmentation were cumulated on a 3-month, 6-month, and 9-month basis, $\left(r^{2}=0.87,0.94\right.$, and 0.96 , respectively). Because

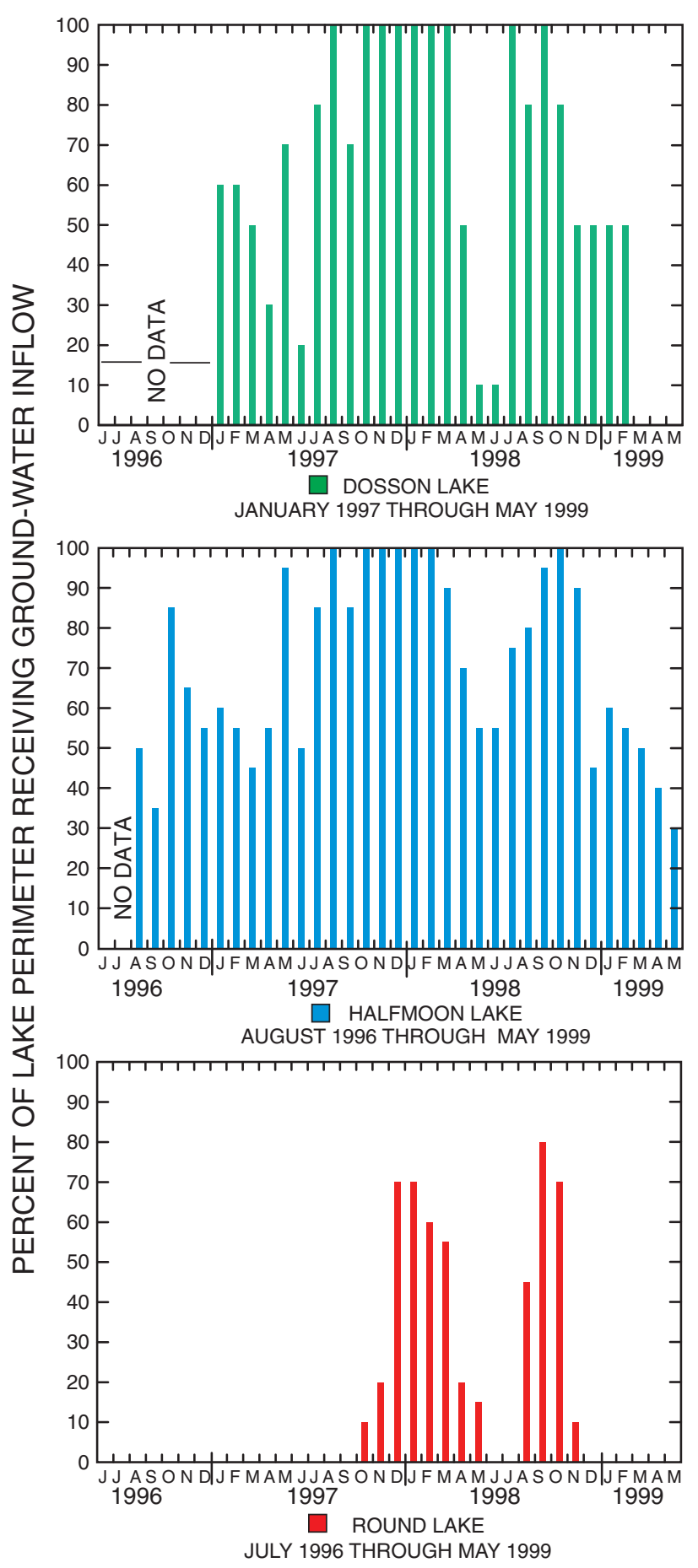

Figure 25. Percentage of lake perimeter receiving groundwater inflow for Dosson Lake, Halfmoon Lake, and Round Lake.

Round Lake resides in a very leaky geologic setting, net ground-water outflow is highly correlated to the amount of augmentation that enters the lake. Monthly augmentation was divided by net ground-water outflow to determine the potential amount of augmentation 
water that returns to the aquifer system. During periods when the lake was routinely augmented, about 100 percent of the augmentation water leaked back to the aquifer system, thus demonstrating the leaky ground-water system at Round Lake.

\section{Annual Ground-Water Flow and Residence Time}

A minimum estimate of total annual groundwater inflow was determined at each lake, by summing all months in which net ground-water inflow was positive. Similarly, a minimum estimate of total annual ground-water outflow was determined using the sum of all of the months in which net ground-water flow was negative. This minimum ground-water inflow was then expressed as a percentage of the total inflows to the lake $\left(\% G_{i}\right)$ :

$$
\% G_{i}=\frac{G_{i}}{\left(P+G_{i}+S_{i}+A\right)},
$$

where $P$ is precipitation, $G_{i}$ is the minimum groundwater inflow, $S_{i}$ is surface-water inflow, and $A$ is augmentation to the lake. The minimum ground-water outflow was similarly expressed as a percentage of the total water losses from the lake $\left(\% G_{O}\right)$ :

$$
\% G_{o}=\frac{G_{o}}{\left(E+G_{o}+S_{o}\right)} \text {, }
$$

where $E$ is evaporation, $G_{o}$ is the minimum groundwater inflow, and $S_{O}$ is surface-water outflow or pumpage out of lake.

Ground-water inflow for each of the three lakes was lowest during the lowest rainfall year and highest during the highest rainfall year (table 7). Annual ground-water inflow was highest at Dosson Lake and ranged from 32 to 46 percent of the total inflows, and averaged 40 percent for the 3 -year study period.

Annual surface-water inflows ranged from 18 to 27 percent of total inflows at Dosson Lake. Annual ground-water inflow was lower at Halfmoon Lake than Dosson Lake and ranged from 6 to 34 percent of the total inflows, and averaged 23 percent for the 3-year study period. Annual ground-water inflow was negligible at Round Lake and was $<1$ percent of total annual inflows. Augmentation to Round Lake accounted for 51 to 84 percent of total annual inflows, and averaged 70 percent for the 3-year study period.

Annual ground-water outflow also varied at each lake for the 3-year data-collection period (table 7). Ground-water outflow from Round Lake was substantially higher than from the two non-augmented lakes, ranging from 75 to 81 percent of total annual outflows

Table 7. Annual estimate of ground-water inflow and outflow for Dosson Lake, Halfmoon Lake, and Round Lake

\begin{tabular}{|c|c|c|c|c|c|c|}
\hline Period & $\begin{array}{c}\text { Net } \\
\text { ground-water } \\
\text { inflow }{ }^{1}\end{array}$ & $\begin{array}{c}\text { Error in } \\
\text { ground-water } \\
\text { inflow }\end{array}$ & $\begin{array}{c}\text { Percent } \\
\text { ground-water } \\
\text { inflow }{ }^{2}\end{array}$ & $\begin{array}{c}\text { Net } \\
\text { ground-water } \\
\text { outflow }^{3}\end{array}$ & $\begin{array}{c}\text { Error in } \\
\text { ground-water } \\
\text { outflow }\end{array}$ & $\begin{array}{c}\text { Percent } \\
\text { ground-water } \\
\text { outflow }^{4}\end{array}$ \\
\hline June 96 - May 97 & 21 & 6 & 32 & 12 & 3 & 15 \\
\hline June 97 - May 98 & 146 & 55 & 46 & 8 & 2 & 3 \\
\hline June 98 - May 99 & 52 & 26 & 42 & 24 & 3 & 16 \\
\hline \multicolumn{7}{|c|}{ Halfmoon Lake } \\
\hline June 96 - May 97 & 3 & 2 & 6 & 15 & 4 & 23 \\
\hline June 97 - May 98 & 44 & 18 & 34 & 12 & 2 & 11 \\
\hline June 98 - May 99 & 19 & 7 & 28 & 24 & 3 & 25 \\
\hline \multicolumn{7}{|c|}{ Round Lake } \\
\hline June 97 - May 98 & 3 & 6 & 2 & 153 & 5 & 75 \\
\hline June 98 - May 99 & 0 & 0 & 0 & 169 & 5 & 76 \\
\hline
\end{tabular}
[Units in inches per year unless otherwise noted]

${ }^{1}$ Annual sum of positive monthly net ground-water flow in tables 3-5, which is the minimum estimate of ground-water inflow.

${ }^{2}$ Ground-water inflow, as percentage of total inflows.

${ }^{3}$ Annual sum of negative monthly net ground-water flow in tables 3-5, which is the minimum estimate of ground-water outflow.

${ }^{4}$ Ground-water outflow, as percentage of total outflows. 
(table 7). Ground-water outflow for the 3-year period was more than 10 times higher than for the non-augmented lakes. Ground-water outflow was slightly greater at Halfmoon Lake than at Dosson Lake (table 7). Ground-water outflow from both Dosson Lake and Halfmoon Lake was greatest during the third waterbudget year, whereas ground-water outflow at Round Lake was greatest during the first year.

Lake-water residence time is an estimate of the average time a molecule of water spends in the lake, and can be calculated by dividing the average lake volume by the sum of the annual inflows (Drever, 1982). The residence time can be used to determine how long it would take to flush a contaminant or the augmented water out of a lake. The residence time is most meaningful when the lakes are in steady-state; therefore, residence time was computed for the 3-year datacollection period.

Halfmoon Lake has the longest lake-water residence time of the three lakes (1.3 years), which is within the range of residence times reported for other lakes in Florida (0.95-5.3 years; Deevey, 1988 and 0.2-3.1 years, computed from data in Sacks and others, 1998). Dosson Lake has a much shorter residence time ( 0.3 year) because of the large ground-water and surface-water flows during the study. Round Lake has a similarly short residence time ( 0.4 year) due to the high volume of augmentation water that is added to the lake each year and is subsequently lost by ground-water outflow.

\section{Evaluation of Net Ground-Water Flow Using Reduced Evaporation Rates}

Uncertainties in the estimated lake evaporation rates were evaluated to determine the affects on the net ground-water flow results. The net ground-water flow term was calculated using a 42 percent reduction in lake evaporation rates, based on the pan evaporation data at Section 21 well field (eq. 2). When the evaporation rates were lowered by 42 percent, net groundwater inflow decreased and net ground-water outflow increased for the three lakes (fig. 26). The largest discrepancies in net ground-water outflow estimates were during the high evaporation months of May through August, and the smallest discrepancies were during low evaporation months of December through February.

Net ground-water flow estimates at Round Lake were relatively unaffected by the uncertainty in evaporation rates, because the annual net ground-water outflow rate was so large that a small increase in ground-water outflow was less significant (table 8).
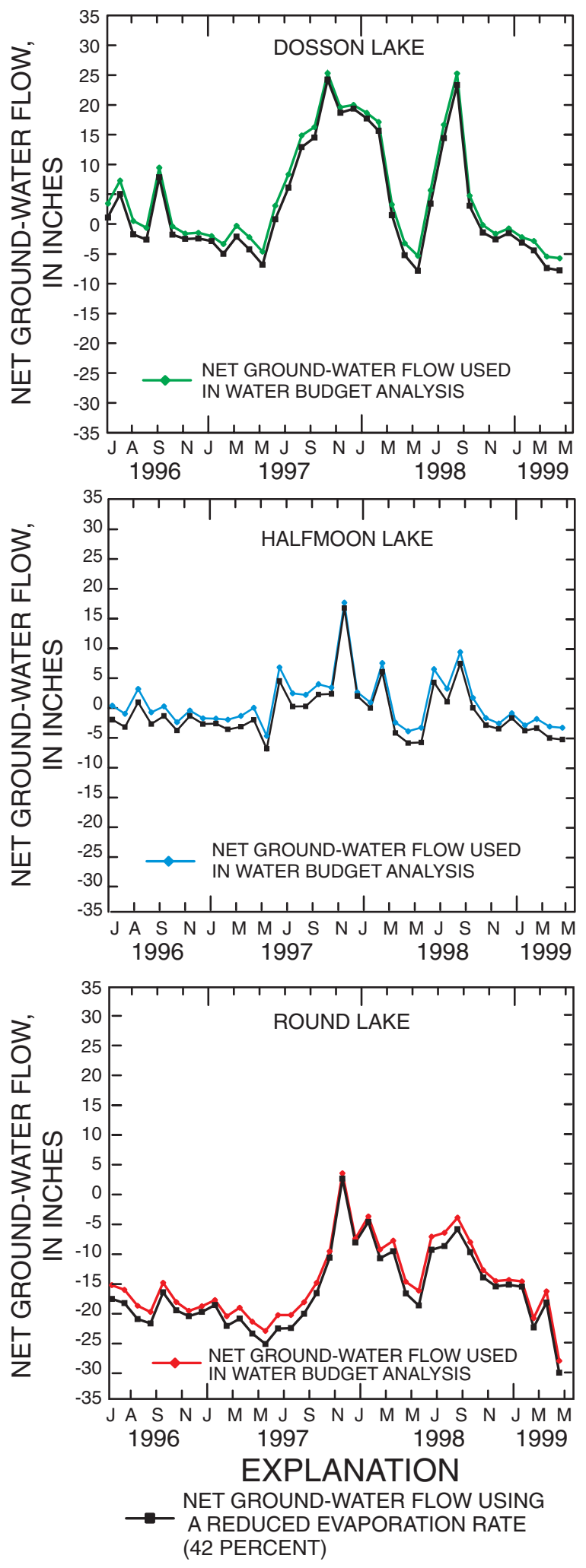

Figure 26. Comparison between net ground-water flow used in the water-budget analysis and net groundwater flow calculated with a 42 percent reduction in lake evaporation. 
Table 8. Evaluation of annual net ground-water flow using a 42 percent reduction in lake evaporation for Dosson Lake, Halfmoon Lake, and Round Lake

[Units in inches per year]

\begin{tabular}{|c|c|c|c|c|c|c|}
\hline Period & $\begin{array}{c}\text { Net } \\
\text { ground-water } \\
\text { inflow }{ }^{1}\end{array}$ & $\begin{array}{l}\text { Net } \\
\text { ground-water } \\
\text { inflow with a } \\
42 \text { percent } \\
\text { reduction in } \\
\text { evaporation }\end{array}$ & $\begin{array}{l}\text { Percent } \\
\text { change }\end{array}$ & $\begin{array}{c}\text { Net } \\
\text { ground-water } \\
\text { outflow }^{3}\end{array}$ & $\begin{array}{c}\text { Net } \\
\text { ground-water } \\
\text { outflow with a } \\
42 \text { percent } \\
\text { reduction in } \\
\text { evaporation }\end{array}$ & $\begin{array}{l}\text { Percent } \\
\text { change }\end{array}$ \\
\hline \multicolumn{7}{|c|}{ Dosson Lake } \\
\hline June 96 - May 97 & 21 & 11 & -48 & 12 & 33 & +175 \\
\hline June 97 - May 98 & 146 & 124 & -15 & 8 & 15 & +88 \\
\hline June 98 - May 99 & 52 & 40 & -23 & 24 & 42 & +75 \\
\hline \multicolumn{7}{|c|}{ Halfmoon Lake } \\
\hline June 96 - May 97 & 3 & 1 & -67 & 15 & 34 & +127 \\
\hline June 97 - May 98 & 44 & 32 & -27 & 12 & 19 & +58 \\
\hline June 98 - May 99 & 19 & 12 & -37 & 24 & 36 & +50 \\
\hline \multicolumn{7}{|c|}{ Round Lake } \\
\hline June 96 - May 97 & 0 & 0 & 0 & 225 & 256 & +14 \\
\hline June 97 - May 98 & 3 & 2 & -33 & 153 & 181 & +18 \\
\hline June 98 - May 99 & 0 & 0 & 0 & 169 & 199 & +18 \\
\hline
\end{tabular}

${ }^{1}$ Annual sum of net ground-water inflow used in the water-budget analysis.

${ }^{2}$ Annual sum of net ground-water inflow with a 42 percent reduction in evaporation.

${ }^{3}$ Annual sum of net ground-water outflow used in the water-budget analysis.

${ }^{4}$ Annual sum of net ground-water outflow with a 42 percent reduction in evaporation.

For the non-augmented lakes, however, annual net ground-water outflow rates were much smaller than at Round Lake, and a small percentage change in evaporation rates had a greater effect on net ground-water flow. Using a 42 percent reduced evaporation rate at Dosson Lake and Halfmoon Lake, annual net groundwater outflow increased at the two lakes by 50 to 175 percent and annual net ground-water inflow decreased by 15 to 67 percent (table 8 ).

In order to increase the accuracy in water-budget results, additional studies are needed to determine accurate evaporation rates and pan coefficients for shallow lakes in coastal areas of west-central Florida. A better understanding also is needed about how lake evaporation is influenced by augmentation water. For example, in the summer months, the addition of relatively cool augmentation water may reduce lake evaporation, whereas in the winter months, the addition of relatively warm augmentation water may increase lake evaporation. Another factor that may influence evaporation of the study lakes is whether lake evaporation is higher at a tannin-stained lake (such as Dosson Lake), which has warmer lake-surface temperatures during the summer, than at a clear-water lake.

\section{WATER QUALITY}

Water-quality and isotopic samples were collected from the three lakes, one rainfall station, and selected wells located in the surficial aquifer, intermediate confining unit, and Upper Floridan aquifer. These water-quality data were used to define the hydrochemical characteristics of the lakes and the surrounding ground-water system. Isotopic samples were used to determine flow patterns in the ground-water system surrounding the three lakes.

\section{Methods}

Lake-water and ground-water quality samples were collected at the three lake basins for the analysis of major ions, nutrients, and the stable isotopes deuterium and oxygen-18. Rainwater was collected at the Section 21 well field climate station for the analysis of deuterium and oxygen-18. Standard USGS protocols were used to collect lake water, ground water, and qualityassurance samples (Wilde and others, 1998). Qualityassurance samples were collected for approximately 10 percent of the samples, including duplicate samples 
and laboratory, equipment, and field-blank samples. The USGS laboratory in Ocala, Fla., analyzed major ions and nutrients for the lake and ground-water samples, and the USGS Isotope Fractionation Laboratory in Reston, Va., analyzed isotope samples. Results of the isotope samples are presented in delta $(\delta)$ notation relative to Vienna Standard Mean Ocean Water. Analytical data are available in the USGS annual data report for southwest Florida (Coffin and Fletcher, 1999a,b and 2000a,b) and in the USGS-maintained database.

The lakes were sampled four times by the USGS for major ions, twice for nutrients, and twice for the isotopes deuterium and oxygen-18 from October 1996 through June 1998. Water-quality samples were first collected at three to four locations in each lake to determine if there were any spatial variability in water quality. When no variability was detected, samples were collected 3 to $4 \mathrm{ft}$ below the lake surface at the center of the lake using a peristaltic pump. At the time of sampling, temperature, $\mathrm{pH}$, specific conductance, and dissolved oxygen were measured in the lake-water column at $1 \mathrm{ft}$ intervals. These field properties also were collected on a monthly basis to determine the seasonal variability within the lake-water column.

The lakes also were sampled on a monthly basis (October 1996 through January 1998) and then on a quarterly basis (April 1998 and July 1998) by SWFWMD personnel. These samples were collected approximately $1.5 \mathrm{ft}$ below the lake surface and $1.5 \mathrm{ft}$ above the bottom sediments at a central station for each lake. Field properties were measured at the top, middle, and bottom of the lake-water column for each lake. Secchi depth also was measured at the time of sampling as an indication of water clarity. The Trophic State Index (Huber and others, 1982), which Florida Department of Environmental Protection uses to evaluate the integrity of lake ecosystems, was calculated for each SWFWMD sample using Secchi depth and chlorophyll $a$, total phosphorus, and total nitrogen concentrations.

Ground water was sampled three times for major ions and nutrients, and twice for deuterium and oxygen18, from October 1996 through June 1998. Samples were collected from wells after three casing volumes were removed from the well. Temperature, $\mathrm{pH}$, dissolved oxygen, and specific conductance were monitored using a flow-through chamber to isolate the sample from the atmosphere. Ground-water samples were collected after field properties stabilized using a peristaltic or submersible pump, depending on the depth to water.
Water from different locations and depth intervals within the surficial aquifer was collected to define the ground-water quality characteristics at each lake basin. Surficial aquifer samples were collected from 7 wells at Dosson Lake, 13 wells at Halfmoon Lake, and 12 wells at Round Lake. Water-quality samples also were collected at well nests to define the vertical distribution of chemical constituents within the intermediate confining unit and the Upper Floridan aquifer. One intermediate confining unit and two Upper Floridan aquifer wells were sampled at each lake basin.

Monthly rainwater samples were collected from the Section 21 well field climate station for deuterium and oxygen-18 from October 1997 through October 1998 to determine the isotopic composition of the local meteoric water line, as discussed in a subsequent section. Samples were collected in a container that was closed to the atmosphere. The methods of collection and sampler design are described in Sacks and others (1998).

\section{Lake Water}

The water quality of each lake has its own distinctive chemical signature, and is influenced by rainfall, land-use practices, ground-water and surfacewater inflow, and ground-water augmentation. Stiff diagrams illustrated in figure 27a represent the median lake-water chemistry from samples collected during the study period. Lake water can be classified based on the composition of dominant ions. A cation or anion is considered a dominant ion when its percentage of the sum of cations or anions is greater than or equal to 50 percent in milliequivalents per liter (Hem, 1985). Comparisons of seasonal field properties and selected chemical constituents also were examined to identify the differences between the non-augmented lakes and the augmented lake (November 1996 through July 1998, fig. 28).

Dosson Lake typically had the lowest specific conductance, $\mathrm{pH}$, temperature, water clarity (based on Secchi depth), and dissolved oxygen and calcium concentrations of the three study lakes (fig. 28, app. B). A low ionic composition and high color content characterize the lake water at Dosson Lake. The median specific conductance of Dosson Lake was 99 microsiemens per centimeter $(\mu \mathrm{S} / \mathrm{cm})$. No dominant ion was present in the lake water, which is classified as a mixed-ion water type based on the median concentration of lake samples (fig. 27a). The water chemistry of Dosson Lake is influenced by the input of rainwater, 


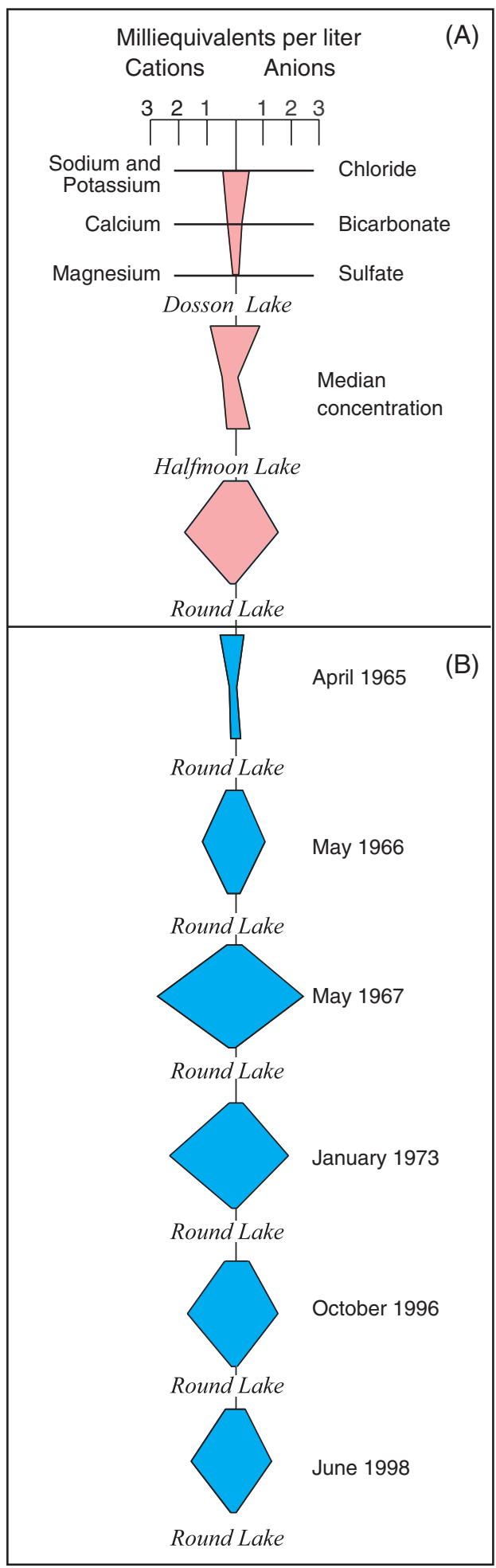

Figure 27. Stiff diagrams for $(A)$ Dosson Lake, Halfmoon Lake, and Round Lake, and (B) historical Stiff diagrams for Round Lake. ground water, and surface-water inflows from the wetlands contiguous with the lake. Total nitrogen and phosphorus concentrations were highest at Dosson Lake than at the other lakes, which may be due to animal waste runoff from pastureland on the west side of the lake or from input of nutrient-rich inflow waters originating in the wetlands (fig. 28). The tea-colored tannic water of Dosson Lake is produced by the interaction of surface-water inflow with the humic soils and plant detritus in the nearby wetlands.

Dosson Lake was the only study lake that had notable stratification of temperature and dissolved oxygen concentrations in the water column (fig. 29). Light does not penetrate the water column as deeply due to the tea-colored tannic waters at Dosson Lake. A temperature decrease of more than 20 degrees Celsius $\left({ }^{\circ} \mathrm{C}\right)$ was observed between the lake surface and the lake bottom during warmer months. The stratification of dissolved oxygen at Dosson Lake was characterized by relatively high dissolved oxygen concentrations near the surface (about 8 milligrams per liter $(\mathrm{mg} / \mathrm{L})$ and low concentrations at the bottom $(<1 \mathrm{mg} / \mathrm{L})$. The stratification of dissolved oxygen was observed for all months when profiles of the water column were measured (May 1996 through June 1998). Dissolved oxygen is higher at the surface of the lake where most of the photosynthesis and aeration with atmospheric oxygen occurs. There are several possible explanations for the large decrease in dissolved oxygen concentrations with depth at Dosson Lake, including: (1) tannic water limits light penetration and, thus, limits the growth of photosynthesizing plants; (2) bacterial oxidation of organic matter near the sediment/lake interface consumes oxygen; (3) oxygen is consumed by chemical oxidation, which occurs in lakes highly stained with humic compounds; and (4) thermal stratification limits the mixing of shallow (higher dissolved oxygen) and deeper (lower dissolved oxygen) waters (Wetzel, 1975, p. 127).

Halfmoon Lake had a higher ionic composition (median specific conductance of $209 \mu \mathrm{S} / \mathrm{cm}$; fig. 28) than Dosson Lake probably due to the greater extent of residential and agricultural development surrounding the lake. Land-use practices associated with residential and agricultural development can result in higher concentrations of ions in ground-water inflow. Halfmoon Lake is classified as a sodium-chloride type water, based on the median concentration of major ions from the lake samples (fig. 27a). Concentrations of chloride, sulfate, sodium, and potassium were higher in Halfmoon Lake than in the other two lakes (fig. 28; app. B). 

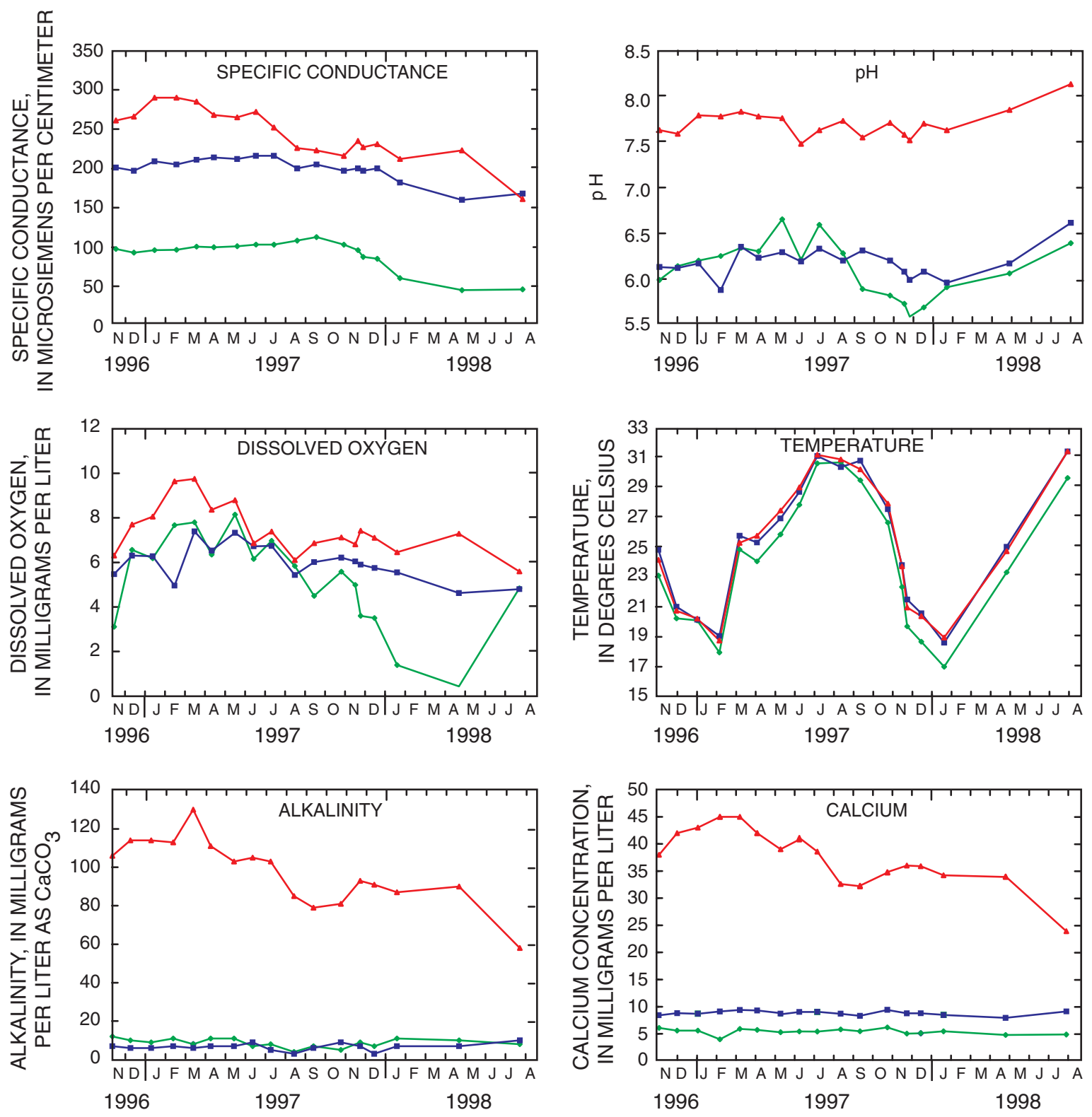

\section{EXPLANATION}

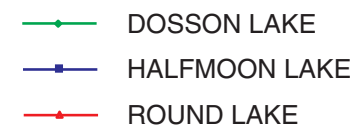

Figure 28. Comparison of field properties and selected chemical constituents for Dosson Lake, Halfmoon Lake, and Round Lake, November 1996 through July 1998. 

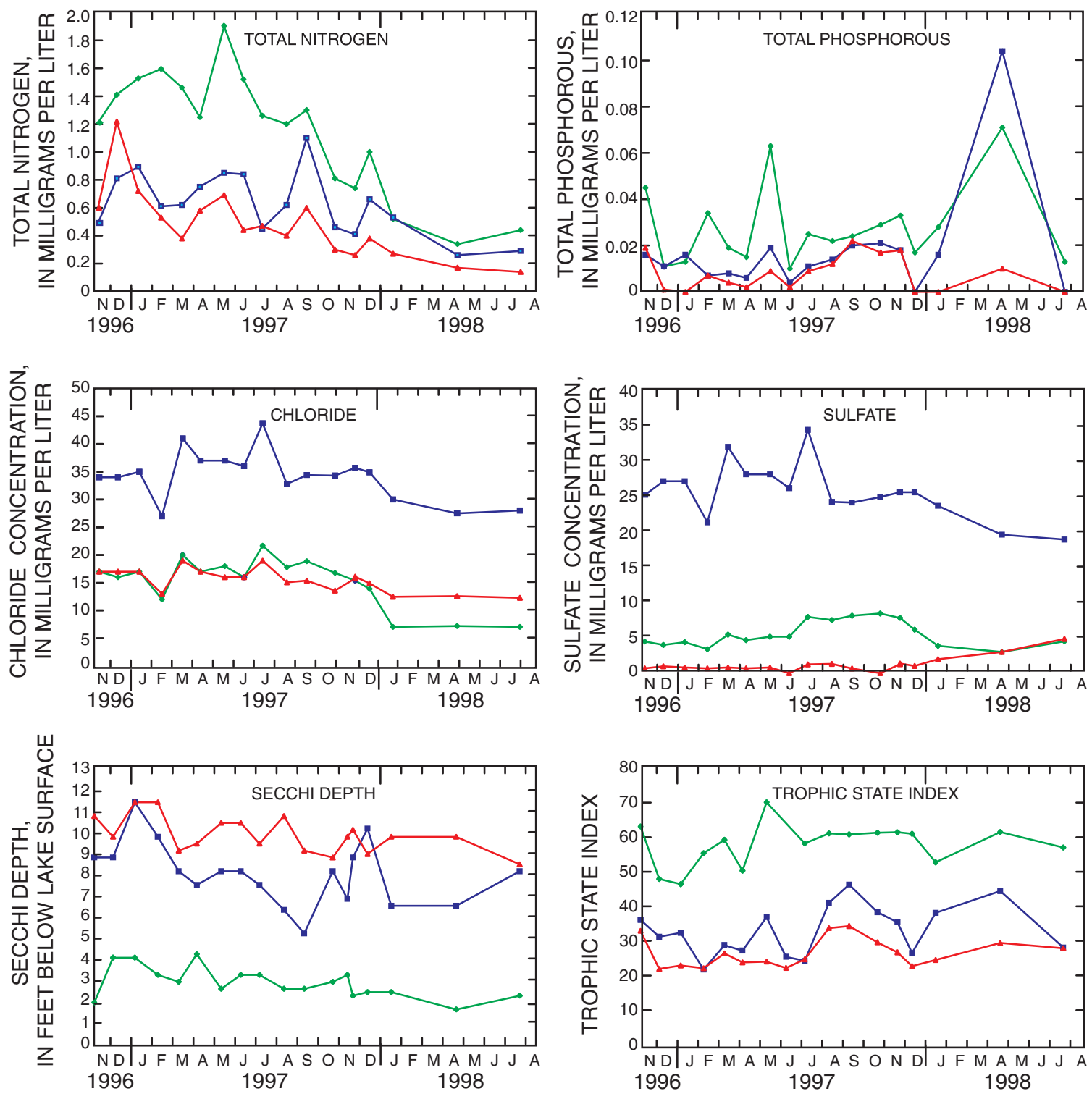

\section{EXPLANATION}

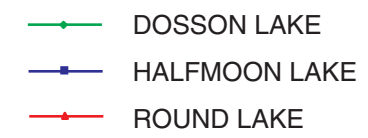

Figure 28. Comparison of field properties and selected chemical constituents for Dosson Lake, Halfmoon Lake, and Round Lake, November 1996 through July 1998. (Continued) 

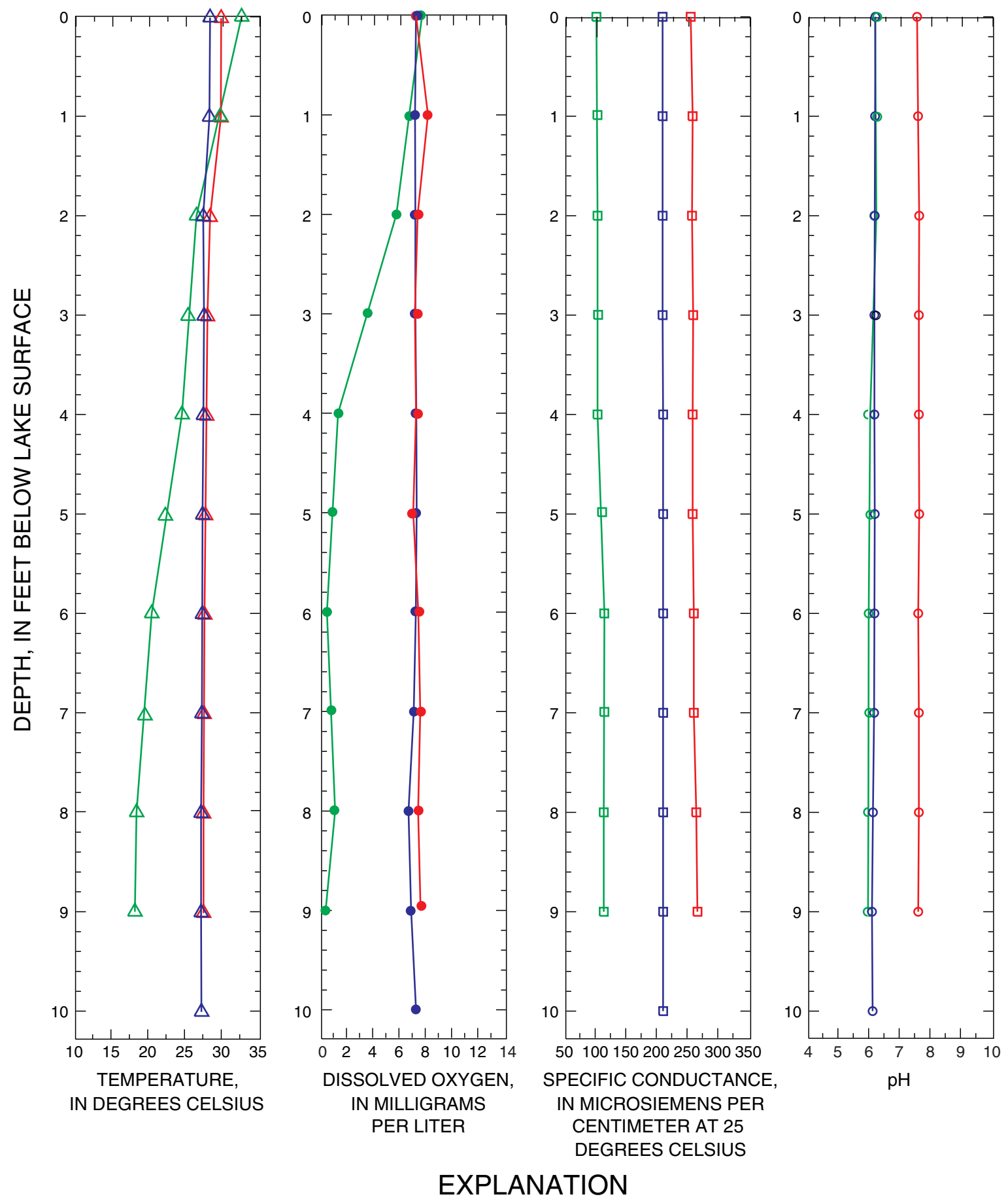

EXPLANATION

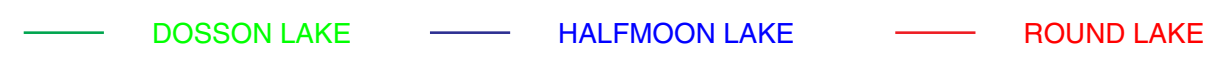

Figure 29. Depth profiles of temperature, dissolved oxygen, specific conductance, and pH for Dosson Lake, Halfmoon Lake, and Round Lake, May 1996. 
These elevated concentrations are probably related to applications of fertilizer from a nearby citrus grove.

Land-use practices associated with citrus agriculture can overwhelm the natural water-quality signature in Florida lakes (Stauffer, 1991; Sacks and others, 1998). Elevated sodium concentrations also can be indicative of septic tank leachate (Alhajjar and others, 1989 and 1990).

Round Lake had the highest specific conductance, $\mathrm{pH}$, alkalinity, water clarity (based on Secchi depth), dissolved oxygen and calcium concentrations, and the lowest nitrogen, phosphorus, and sulfate concentrations of the three study lakes (fig. 28; app.B). Round Lake is classified as a calcium-bicarbonate water type (fig. 27a), which is the result of the input of large volumes of calcium-bicarbonate enriched augmentation water from the Upper Floridan aquifer. Augmentation water accounted for 70 percent of the inflow to Round Lake during the study period (see Annual GroundWater Flow and Residence Time section), which strongly influences the chemistry of the lake.

Comparison of historical Stiff diagrams reveals the effects of augmentation on the water chemistry of Round Lake (fig. 27b). Prior to augmentation of the lake (April 1965), the chemical composition of Round Lake was similar to Dosson Lake. The historical lake sample had a lower specific conductance, $\mathrm{pH}$, alkalinity, and dissolved oxygen and calcium concentrations, than lake samples collected after augmentation. The Stiff diagrams based on the water chemistry after augmentation (1966, 1967, and 1973) indicates that the lake was dominated by calcium bicarbonate. The amount of ground-water augmentation that is used to maintain lake levels at Round Lake varies with the amount of rainfall and affects the ionic composition of the lake. For example, the lake had slightly higher calcium and bicarbonate concentrations (October 1996) when the augmentation was relatively high, than later in the study (June 1998), following a period of high rainfall and low augmentation (fig $27 \mathrm{~b}$ ).

Several chemical consequences have occurred as a result of adding calcium-carbonate enriched ground water from the Upper Floridan aquifer to Round Lake. Calcium carbonate precipitate was observed as a white, flocculent material on the lake bottom and on the surface of the aquatic vegetation. Geochemical analysis of the lake water indicates that it was often saturated to supersaturated with respect to calcite (13 of 20 samples), and thus, conditions were favorable for calcite precipitation. In addition, sediment cores at Round
Lake (Brenner and Whitmore, 1999) showed a marked increase in calcium and inorganic carbon concentrations in the uppermost sediments (about $0.5 \mathrm{ft}$ ), indicating that calcium carbonate is accumulating in the sediments. The increase of calcium carbonate within the sediments is probably due to a combination of calcium carbonate precipitate and the growth and accumulation of macrophytes such as Nitella sp. and of carbonate-rich snails such as Planorbella sp., which both thrive in high alkalinity lake water.

Round Lake is notably clear (median Secchi depth reading of approximately $10 \mathrm{ft}$ ) compared to the other study lakes. The clarity of the lake water may be the result of the addition of large volumes of ground water with low total suspended solids, which leaks out rapidly from the lake. The clarity also may be the result of low concentrations of nitrogen and phosphorus, which limit the growth of phytoplankton (fig. 28). Brenner and Whitmore (1999) suggest that the relatively low phosphorus concentrations in the water column of Round Lake could be the result of the co-precipitation of phosphorus with calcium carbonate. Because of the high lake clarity, light penetration also is high through the water column, which enables a thick vegetative mat to grow over most of the sandy lake bottom. An increase in photosynthesizing aquatic vegetation results in higher dissolved oxygen concentrations in the lake (fig. 28).

An unanticipated consequence of adding ground water to Round Lake was the high radium-226 activities in the near-surface lake sediments and in the biota of the lake (Brenner and Whitmore, 1999; Brenner and others, 2000). The radium-226 activity levels (about 27 disintegrations per minute per dry mass; $\mathrm{dpm} \mathrm{g}^{-1}$ ) in the upper $0.5 \mathrm{ft}$ of sediments was one of the highest levels measured in a Florida lake (Brenner and Whitmore, 1999; and Brenner and others, 1994, 1997, 2000). In comparison, the radium-226 activitiy levels for Dosson Lake and Halfmoon Lake were 2.7 and $7.4 \mathrm{dpm} \mathrm{g}^{-1}$, repectively. Elevated radium-226 levels in the sediments are a consequence of augmenting the lake with ground water with relatively low levels of radium-226 (5.8 dpm per liter) for more than 30 years (Brenner and others, 2000). Radium-226 occurs naturally in ground water and is commonly associated with the clay minerals of the intermediate confining unit, which have elevated concentrations of radium and radionuclides. As recharge water passes through the intermediate confining unit to the Upper Floridan aquifer, chemically active ground water can leach out radium-226. The solubility of 
radium-226 is enhanced by cations already in solution, such as calcium (Kaufmann and Bliss, 1977). Radium is chemically similar to calcium and tends to follow similar chemical and biological pathways as calcium. High radium-226 activity levels were detected in the sediments, aquatic plants, fish bones, mollusk shells, and mollusk tissue in which calcium is a major component. Brenner and others (2000) provide a detailed discussion pertaining to the accumulation of radium-226 in Round Lake. Further investigations are underway in other lakes in the region to better understand the extent of biological and chemical accumulation of radium-226.

All three lakes were classified as having good water quality, based on the median Trophic State Index (TSI) values: 58, 33, and 27 for Dosson Lake, Halfmoon Lake and Round Lake, respectively. A TSI value of 0-59 for Florida lakes indicates that the water quality is good, $60-69$ is fair, and 70-100 is poor. Water quality in Dosson Lake was classified as borderline good/fair for several months during the study period because of shallow Secchi depth readings and high chlorophyll $a$, total phosphorus, and total nitrogen concentrations. Water quality in Round Lake was classified as the best because of low chlorophyll a, total nitrogen, and total phosphorus concentrations, and deep Secchi depth readings (fig. 28). Low TSI values at Round Lake are probably due to the short residence time of the lake water and the large input of relatively low nutrient ground water.

\section{Ground Water}

Water quality within the surficial aquifer varied widely, both seasonally and spatially at each lake basin (app. C). The variability in dissolved chemical constituents in the surficial aquifer suggests that ground water is affected by localized surface conditions. Because the surficial aquifer is contiguous with land surface and composed of sand with relatively high permeability, the chemical composition of water in the surficial aquifer is affected by land-use practices such as fertilizer application, leakage from septic-tank effluent, irrigation from the Upper Floridan aquifer, and lake leakage from augmentation.

Water chemistry of the intermediate confining unit and Upper Floridan aquifer is controlled by the lithology and mineralogy of the particular unit, residence time of water in contact with the aquifer matrix, and recharge from the overlying aquifer. Water quality within the intermediate confining unit varied spatially and was similar to the water chemistry in the overlying surficial aquifer at each lake basin (app. D). The water chemistry in the Upper Floridan aquifer was dominated by calcium bicarbonate at each lake basin, which is the result of the dissolution of calcite in the limestone aquifer (app. D). Stiff diagrams were used to compare the chemistry of the lakes with the surrounding ground water and to illustrate water-quality changes with depth at the well nests (fig. 30).

Ground water in the surficial aquifer at Dosson Lake was more dilute than at the other two lakes and was typically dominated by sodium and chloride (fig. 30). The Dosson Lake basin is less developed than the Halfmoon Lake and Round Lake basins, which probably results in lower chemical input to water recharging the surficial aquifer. However, sodium and chloride concentrations are slightly enriched compared to surficial aquifer water in undeveloped lake basins, and could be the result of septic-tank leachate, fertilizer application, or possibly animal waste from pastureland on the west side of the lake. Nitrate-plus-nitrite concentrations were low for all wells sampled in the Dosson Lake basin (maximum concentration $0.14 \mathrm{mg} / \mathrm{L}$ as $\mathrm{N}$, app. C). A well nest on the western side of the lake indicates that water from the intermediate confining unit was similar to the chemistry of the overlying recharge waters from the surficial aquifer (well nest DL3 and DL2 in fig. 30). Water from the Upper Floridan aquifer at Dosson Lake had considerably higher calcium and bicarbonate concentrations than water from the surficial aquifer and intermediate confining unit, because of limestone dissolution (well nest DL1 in fig. 30; app. D).

Water in the surficial aquifer surrounding Halfmoon Lake had higher concentrations of dissolved inorganic constituents than the Dosson Lake basin (fig. 30 and app. C). These higher concentrations are probably due to the greater amount of residential and agricultural development surrounding Halfmoon Lake. Surficial aquifer water quality varied widely for Halfmoon Lake, and probably is the result of different landuse practices affecting the water quality within the lake basin. A well nest (well nest HML 7, 8, 30, 31 in fig. 30) on the eastern side of Halfmoon Lake, where the majority of ground-water inflow to the lake occurs, is down gradient from a relatively large citrus grove (25 acres). The surficial aquifer water in this well nest had the highest nitrate-plus-nitrite concentrations of all wells sampled (9.6 mg/L; app. C). Water from the surficial aquifer well nest also had high potassium, 


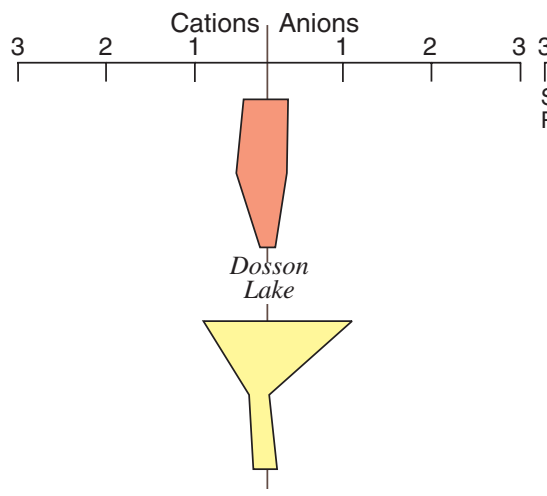

DL25 (index number 96)

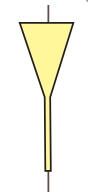

DL26 (index number 97)

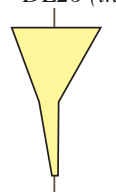

DL27 (index number 98)

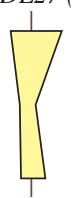

DL3 (index number 75

$\square$ well nest)

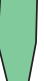

DL2 (index number 74

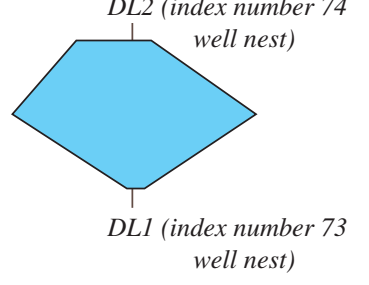

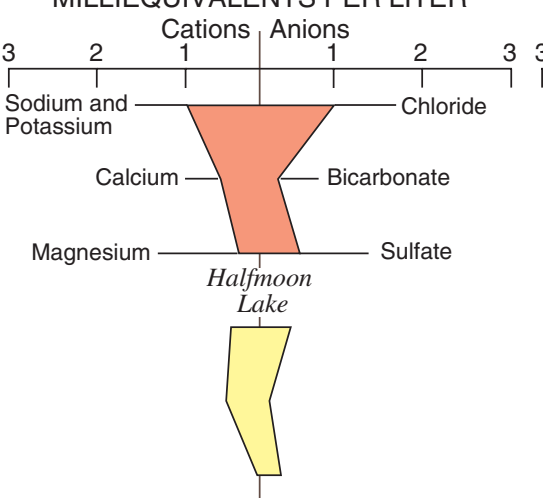

HML10 (index number 43)

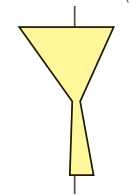

HML24 (index number 57)

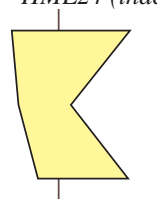

HML7 (index number 39

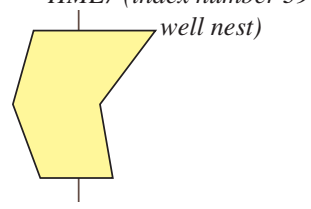

HML8 (index number 40

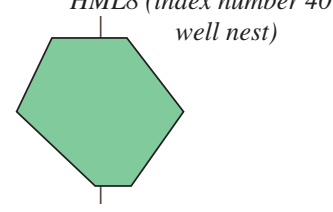

HML30 (index number 63

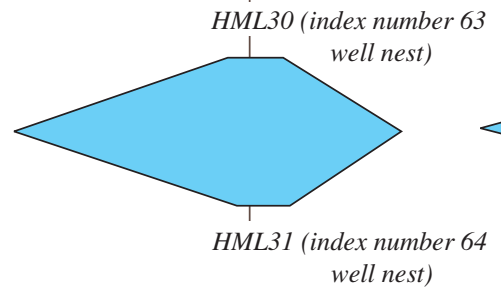

well nest)

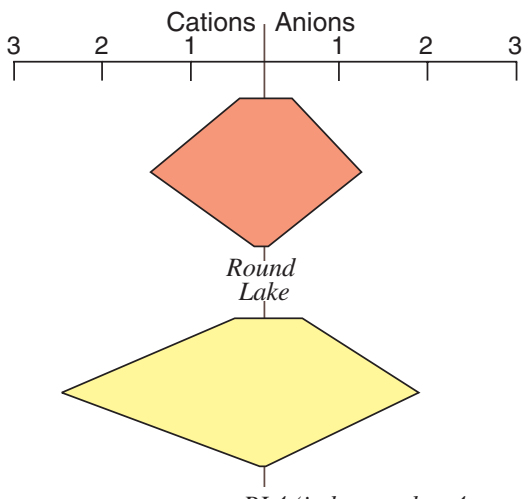

RLA (index number 4

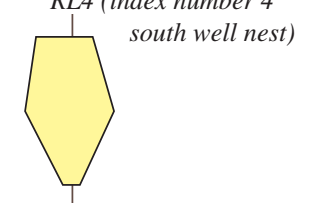

RL3 (index number 3

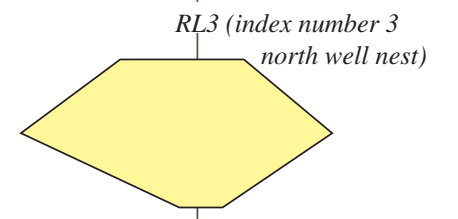

RL2 (index number 2

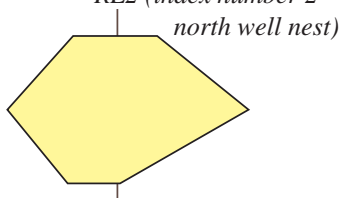

RL23 (index number 23

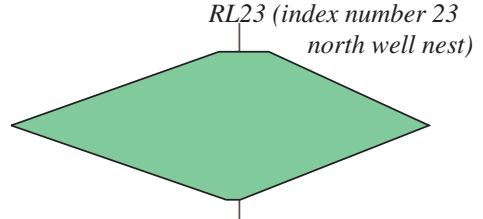

RL22 (index number 22

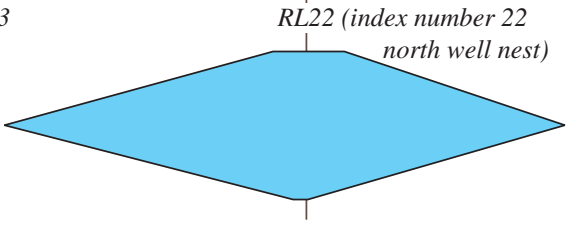

RL Augmentation (index number 26 north well nest)

\section{EXPLANATION}

LAKE WATER

INTERMEDIATE CONFINING UNIT WATER

SURFICIAL AQUIFER WATER

UPPER FLORIDAN AQUIFER WATER

Figure 30. Stiff diagrams for the lake water and ground water at Dosson Lake, Halfmoon Lake, and Round Lake, June 1998. (Well sites shown in figures 3,4 , and 5.) 
chloride, and sulfate concentrations. These same constituents have been observed in shallow ground water in areas of citrus agriculture in ridge areas of central Florida (Stauffer, 1991; German, 1997; Sacks and others, 1998). Nitrate-plus-nitrite and associated ions decreased in concentration in the intermediate confining unit and Upper Floridan aquifer, compared to the surficial aquifer (app. C and D). These lower concentrations could be because much of the shallow ground water in this area moves laterally into the lake, rather than downward, due to a rather steep lateral inflow gradient $(0.01 \mathrm{ft} / \mathrm{ft})$. Similar to the Dosson Lake ground water, water chemistry in the intermediate confining unit was influenced by the overlying recharge waters and the Upper Floridan aquifer was influenced by limestone dissolution (fig. 30).

Calcium and bicarbonate concentrations at Round Lake were much higher in the shallow ground water than at the non-augmented lakes (fig. 30; app. C). Because the lake level at Round Lake is typically higher than the adjacent water table, lateral outflow of augmented lake water results in elevated calcium and bicarbonate concentrations in the surficial aquifer.

However, elevated calcium and bicarbonate concentrations progressively decrease away from the lake. Water from some shallow wells surrounding Round Lake also had high sodium, chloride, and sulfate concentrations, which are related to land-use practices. As high volumes of the chemically enriched ground water from the surficial aquifer move downward at Round Lake, the intermediate confining unit and Upper Floridan aquifer are influenced by the chemical composition of overlying recharge waters (well nest RL3, 2, 23, 22 and RL augmentation in fig. 30; app. D). The chemistry of the Upper Floridan aquifer also is influenced by limestone dissolution.

\section{Saturation State of Lake and Ground Water at Round Lake}

The geochemical composition of lake water and ground water at Round Lake was evaluated to determine whether the leakage of augmented lake water into the aquifer systems could affect the solubility of limestone beneath
Round Lake. The geochemical model WATEQF (as part of NETPATH; Plummer and others, 1994) can calculate the saturation state of the sampled water with respect to calcite. If water is undersaturated (saturation index less than zero, with an associated range of uncertainty), the water is capable of dissolving calcite, and if the water is saturated or supersaturated (saturation index equal to or greater than zero), the water is not capable of dissolving calcite. Calcite saturation (or equilibrium) is assumed when the calcite saturation index is between -0.15 and 0.15 after taking into account analytical uncertainties. Saturation indexes were calculated for 20 lake-water and 14 ground-water samples that were collected within the Round Lake basin between October 1996 and July 1998.

The saturation state of Round Lake is controlled by the high calcium and bicarbonate concentrations from augmentation water, along with lake-water $\mathrm{pH}$. Of the 20 lake-water samples collected at the augmented lake, 10 were saturated, 3 were supersaturated, and 7 were undersaturated with respect to calcite (fig. 31; table 9). In comparison, lake-water samples collected at the non-augmented lakes were all undersaturated with respect to calcite (saturation index -1.8 to -3.6$)$. Water tended to be undersaturated at Round Lake when augmenation was low and during and following wet periods, when rainwater probably dilutes the calcium and bicarbonate concentrations.

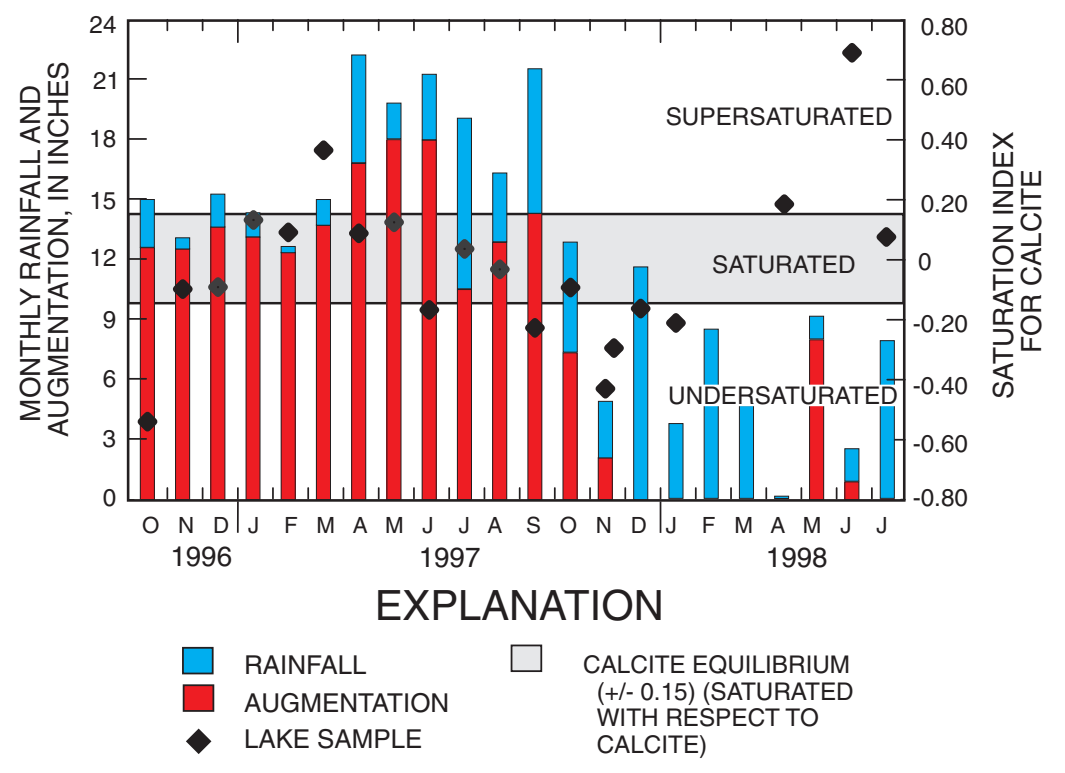

Figure 31. Seasonal saturation index with respect to calcite for Round Lake, October 1996 through July 1998. 
Table 9. Saturation state of lake and ground-water samples with respect to calcite for the Round Lake basin

[SI cal, saturation index for calcite; SA, surficial aquifer; ICU, intermediate confining unit; UFA, Upper Floridan aquifer; RL aug, Round Lake augmentation]

\begin{tabular}{|c|c|c|c|c|}
\hline $\begin{array}{l}\text { Well or } \\
\text { lake name }\end{array}$ & $\begin{array}{c}\text { Index } \\
\text { number }{ }^{1}\end{array}$ & $\begin{array}{c}\text { Sample } \\
\text { date }\end{array}$ & $\begin{array}{l}\text { Sample } \\
\text { location }\end{array}$ & $\begin{array}{l}\text { SI } \\
\text { cal }^{2}\end{array}$ \\
\hline RL5 & 5 & $10 / 28 / 96$ & SA & -1.43 \\
\hline RL5 & 5 & $11 / 04 / 97$ & SA & -1.78 \\
\hline RL5 & 5 & 06/04/98 & SA & -1.21 \\
\hline RL4 & 4 & $10 / 28 / 96$ & SA & -1.26 \\
\hline RL4 & 4 & $11 / 05 / 97$ & SA & -1.45 \\
\hline RL4 & 4 & $06 / 04 / 98$ & SA & -1.00 \\
\hline RL2 & 2 & $11 / 03 / 97$ & SA & -1.73 \\
\hline RL2 & 2 & $06 / 02 / 98$ & SA & -1.74 \\
\hline RL23 & 23 & $11 / 04 / 97$ & SA & -0.87 \\
\hline RL23 & 23 & $06 / 04 / 98$ & SA & -1.62 \\
\hline RL22 & 22 & $11 / 07 / 97$ & $\mathrm{ICU}$ & 0.33 \\
\hline RL22 & 22 & $06 / 04 / 98$ & ICU & -0.79 \\
\hline RL aug & 26 & $10 / 24 / 96$ & UFA & -0.26 \\
\hline RL aug & 26 & $11 / 05 / 97$ & UFA & -0.20 \\
\hline Round Lake ${ }^{3}$ & & average & Lake & -0.03 \\
\hline Round Lake ${ }^{3}$ & & minimum & Lake & -0.54 \\
\hline Round Lake ${ }^{3}$ & & maximum & Lake & 0.69 \\
\hline
\end{tabular}

${ }^{1}$ Refer to index number in appendix A for well construction information and figure 5 for well locations.

${ }^{2}$ Ground water selected with calcium concentrations greater than 30 milligrams per liter and alkalinity greater than 100 miligrams per liter as calcium carbonate.

${ }^{3}$ Based on 20 lake-water samples collected from October 1996 through July 1998.

Calcite precipitation probably controls the concentrations of calcium and bicarbonate within the water column, and the lake water tended to be saturated with calcite for much of the sampling period. Supersaturation with calcite occurred during low rainfall periods, and when evaporation and augmentation were high (April-June 1998; fig. 31).

Most ground water in the Round Lake basin was undersaturated with respect to calcite (table 9). Calcium and bicarbonate concentrations in ground water were typically similar to or greater than lakewater concentrations, but lower $\mathrm{pH}$ values in ground water result in undersaturated conditions. Only one water sample (RL22 well, November 1997, from the intermediate confining unit) was saturated or supersaturated with calcite (saturation index of 0.33 ). Water from the Round Lake augmentation well was slightly undersaturated with calcite (saturation index -0.26 and
-0.20), indicating that the water is capable of dissolving calcite in the Upper Floridan aquifer. Ground water beneath the lake is presumably undersaturated with respect to calcite because of mixing between surficial aquifer water and the lake water.

The Round Lake area has the potential for increased karst activity (subsidence, sinkhole formation, and limestone dissolution) because of the large volume of water moving downward from the surficial aquifer to the Upper Floridan aquifer. The undersaturation of ground water with respect to calcite indicates that karst activity may not only be influenced by mechanical flow, but also by increased chemical dissolution (Moore, 1989). As large volumes of augmented lake water flow out laterally, the lake margins may be particularly vulnerable to increased limestone dissolution because the lateral outflow mixes with naturally acidic waters of the surficial aquifer, resulting in chemically aggressive ground water.

\section{Isotope Tracer}

The naturally occurring isotopes deuterium and oxygen-18 are stable isotopes of the water molecule. Deuterium $\left({ }^{2} \mathrm{H}\right)$ is the heavier isotope of hydrogen $\left({ }^{1} \mathrm{H}\right.$ most abundant form), and oxygen-18 $\left({ }^{18} \mathrm{O}\right)$ is the heavier isotope of oxygen $\left({ }^{16} \mathrm{O}\right.$ most abundant form). Evaporation causes lake water or surface water to become enriched in the heavier isotopes because lighter isotopes have a higher vapor pressure and preferentially evaporate (Krabbenhoft and others, 1994). Differences in enrichment of isotopes among lakes can give a general indication of the lake-water residence time and the amount of flow to the lake. For example, when a lake is isotopically lighter (smaller $\delta$ value) than a nearby lake, the lake has a shorter lake-water residence time and has more ground-water or surface-water inflows to the lake. Conversely, when a lake is isotopically heavier (larger $\delta$ value) than another lake, the lake has a longer residence time and has less ground-water or surface-water inflows to the lake. The enrichment or lack of enrichment of these isotopes is useful in determining flow paths between lakes and the surrounding ground-water flow system. Isotopically heavy ground water near a lake can indicate areas of lake leakage, because lake water is more enriched in heavier isotopes than ground water. 


\section{Rainwater}

Rainwater collected monthly at the Section 21 well field (Lake Park) falls along a linear trend, called the meteoric water line, when plotting deuterium in relation to oxygen-18 (fig. 32). The relation between deuterium $(\delta \mathrm{D})$ and oxygen-18 $\left(\delta^{18} \mathrm{O}\right)$ values of rainwater collected during this study was not statistically different, at a 95 percent confidence interval, from the global meteoric water line defined by Craig (1961). Ground-water samples plotting along this line indicate that the water has undergone minimal evaporation (fig. 32). Monthly and volume-weighted mean isotopic data from rainfall samples at Section 21 well field are shown in appendix E.

\section{Lake Water}

Dosson Lake had the lightest isotopic signature compared to the other study lakes, which is undoubtedly related to greater amounts of surface-water and ground-water inflow to the lake (fig. 32; table 3). Halfmoon Lake, which has no surface-water inflow, is isotopically heavier than Dosson Lake. This heavier isotopic signature at Halfmoon Lake indicates that the lake water has undergone more extensive evaporation than Dosson Lake, and has a longer lake-water residence time. Round Lake has a lighter isotopic composition compared to Halfmoon Lake, which indicates a shorter lake-water residence time. The dominant inflow to Round Lake is augmented ground water and its isotopic composition reflects the evaporative enrichment of this augmentation water. These qualitative results are consistent with average residence times computed from water budgets: 0.3 years for Dosson Lake, 1.3 years for Halfmoon Lake, and 0.4 years for Round Lake.

Ground-water inflow to lakes can be computed from an isotope mass balance of the lakes (Dincer, 1968; Krabbenhoft and others, 1990; Sacks and others, 1998). The mass-balance approach was attempted for this study, but unreliable results were computed. Unusually high rainfall when the lakes were sampled for isotopes (December 1997 through June 1998) possibly caused the steady-state assumption to be violated. A nonsteady-state formulation of the equation was also attempted for this study. However, large uncertainties in surface-water inflow rates and in the isotopic composition of the inflow water resulted in unreliable results for Dosson Lake. Uncertainties in the isotopic composition of atmospheric moisture and lake water caused large uncertainties in the calculated ground-water inflow for all three lakes. The isotope mass-balance approach is more reliable for seepage lakes with no surfacewater flows, for lakes with longer lake-water residence times than Dosson Lake and Round Lake, and when climatic conditions are more stable than existed during the study period.

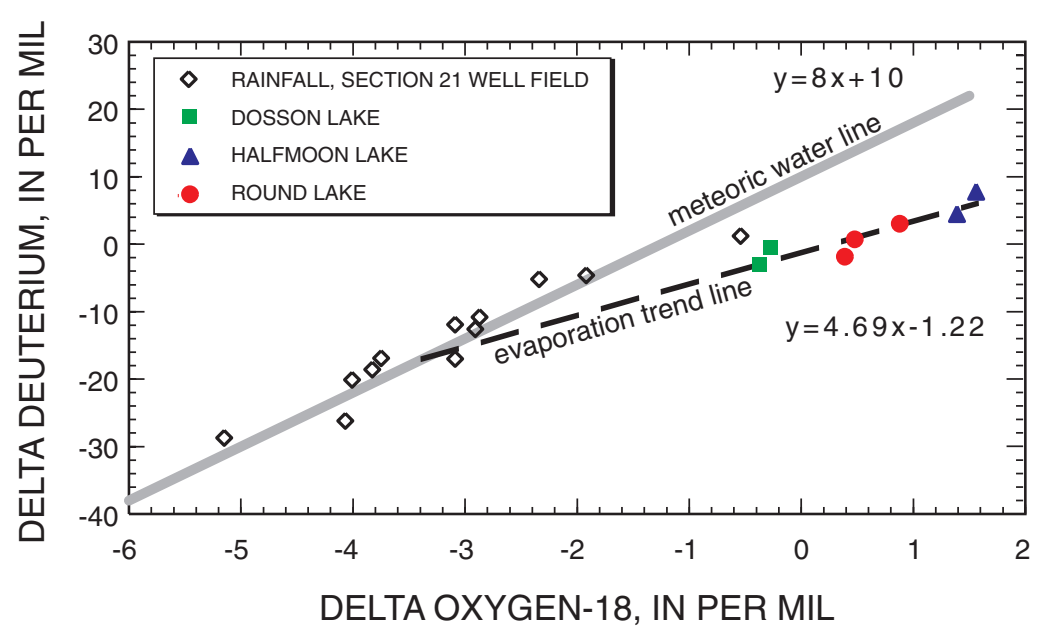

Figure 32. Delta deuterium plotted against delta oxygen-18 for rainwater from Section 21 well field and lake water from Dosson Lake, Halfmoon Lake, and Round Lake, October 1997 through October 1998.

\section{Ground Water}

Most ground water at Dosson Lake was isotopically similar to meteoric water, indicating ground water has undergone minimal evaporation (fig. 33a). However, water from two wells in the wetlands to the north and south side of the lakes (DL27 and DL25; index numbers 98 and 96, respectively), are enriched in heavy isotopes and plot along the evaporation trend line (fig. 33a). The evaporative enrichment of this ground water may be indicative of lake leakage during dry periods, when the water table was lower than the lake in these areas (fig. 12a). Alternatively, the evaporative enrichment may occur locally in the wetlands (ponded water or from the soil) before recharging the ground water. 

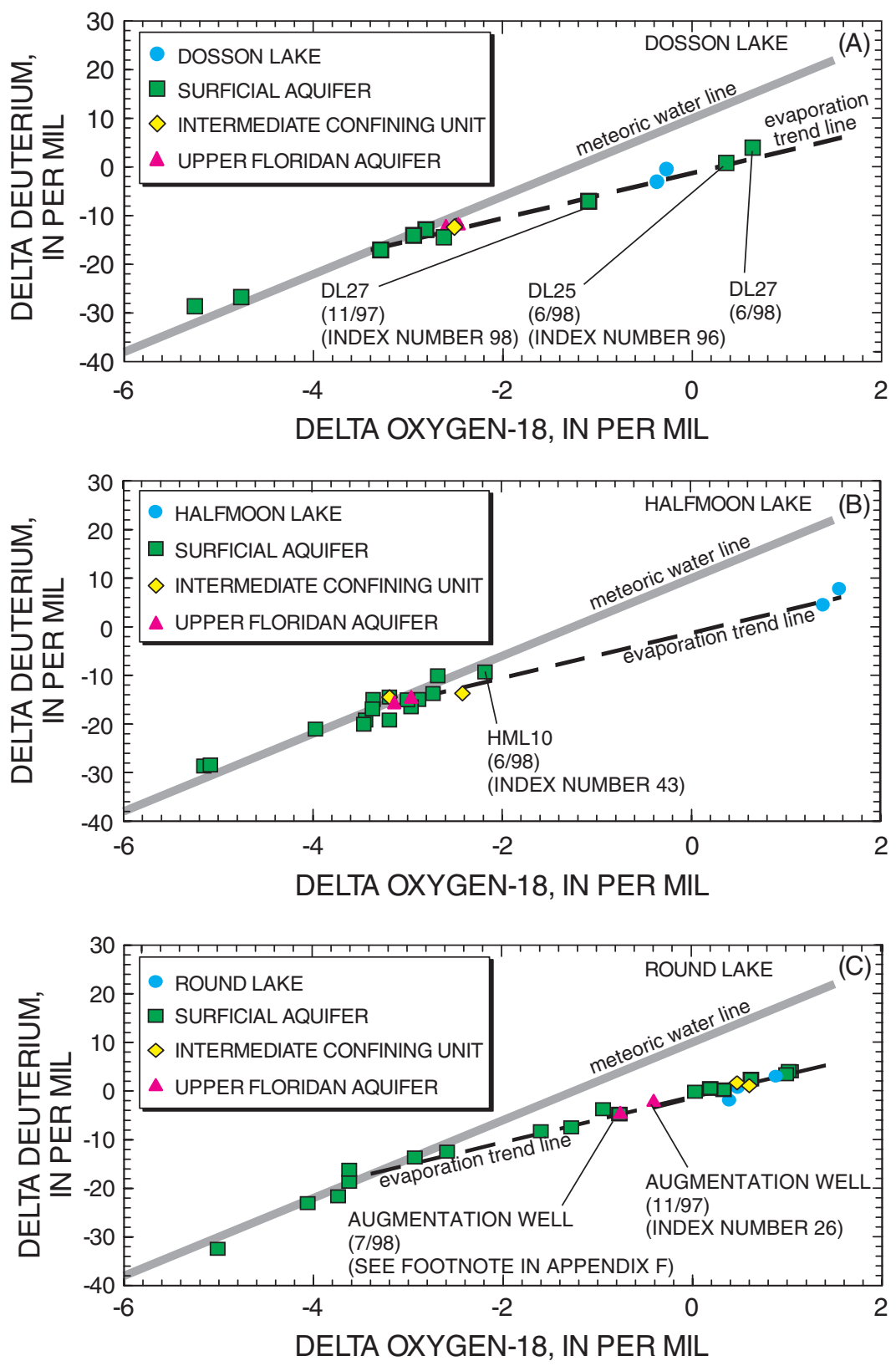

Figure 33. Delta deuterium plotted against delta oxygen-18 for ground water and lake water at (A) Dosson Lake, (B) Halfmoon Lake, and (C) Round Lake, October 1997 through October 1998.

There was little isotopic variability between the surficial aquifer, intermediate confining unit, and Upper Floridan aquifer at the well nest on the western side of Dosson Lake (DL3, DL2, and DL1; fig. 34). Water from the deeper wells were slightly more enriched in heavy isotopes than the shallower ones, which may be the result of natural outflow from the lake to the Upper Floridan aquifer.
Most of the ground water sampled at Halfmoon Lake showed no evidence of lake leakage. Ground-water inflow occurred around the entire lake perimeter during the December 1997 sampling, and most of the ground water plotted near the meteoric water line (fig. 33b). Ground-water outflow occurred on the western side of the lake (fig. 12c-d) during the June 1998 sampling, and water from one well on the western side of the lake 

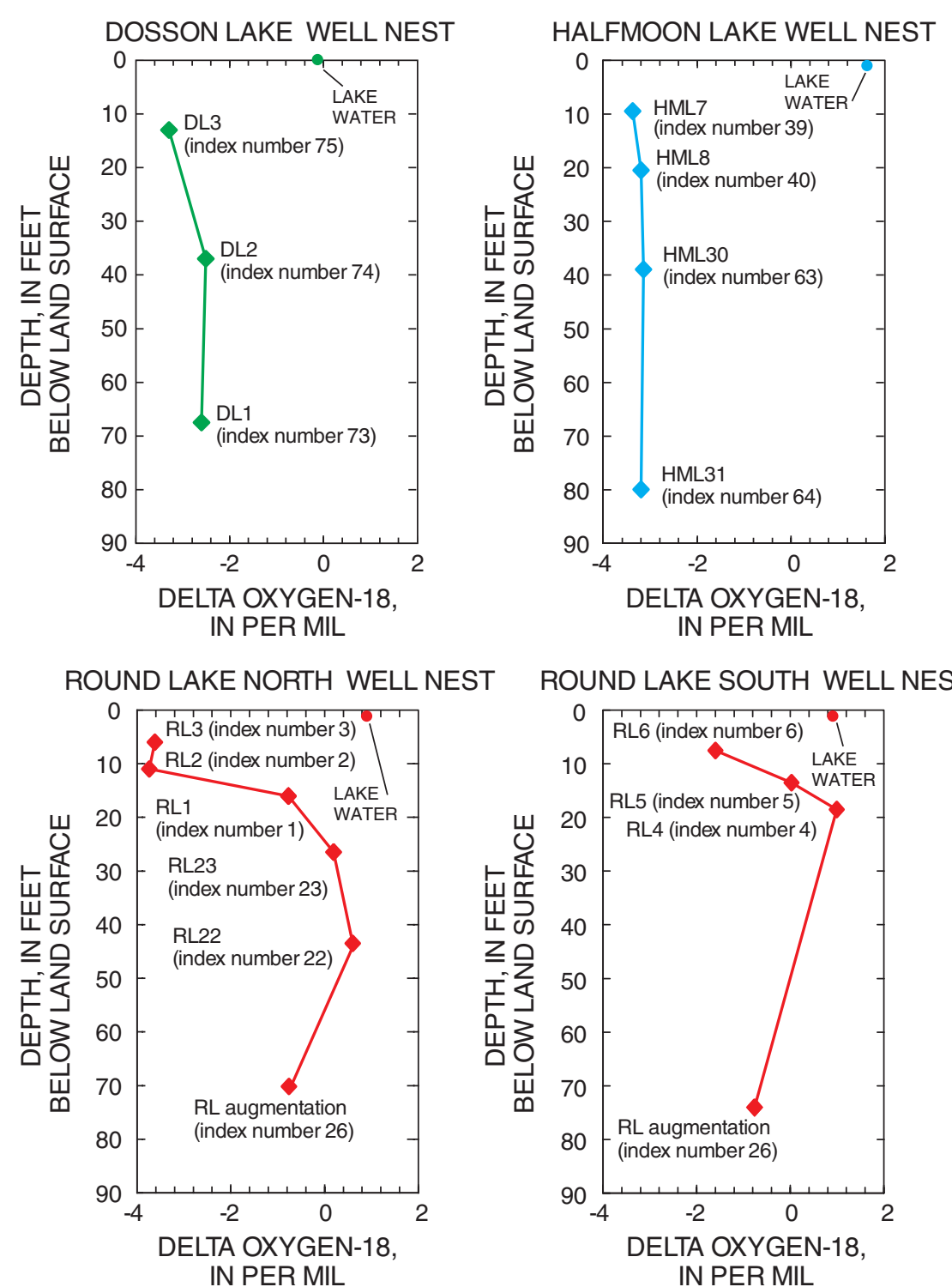

Depths plotted at the average screened or open-hole interval for the well, except for the augmentation well at Round Lake, which is plotted for illustrative purposes at the depth of the top of the open-hole interval.

Figure 34. Delta oxygen-18 in water from well nests at Dosson Lake, Halfmoon Lake, and Round Lake, June 1998.

(HML10; index number 43) had a slightly heavier isotopic composition than the other wells sampled. The water level in this well was $0.14 \mathrm{ft}$ lower than the lake, and the isotopic composition of this water probably reflects a small fraction of lake leakage. At the well nest on the eastern side of Halfmoon Lake (HML7, 8, 30 , and 31; fig. 34), which is a ground-water inflow area, there was little isotopic variability in ground water between the aquifers, and there was no evidence of isotopic enrichment from lake leakage.
In the Round Lake basin, water from many of the wells in the surficial aquifer, intermediate confining unit, and Upper Floridan aquifer were enriched with heavy isotopes, indicating the influence of lake leakage (fig. 33c). Water from the shallowest wells in the water table tended to be less enriched than deeper wells in the surficial aquifer. Water from half of the water-table wells sampled near Round Lake did not indicate lake leakage. The November through December 1997 samples were collected during an above-normal recharge 
period, when the water table was at a relatively high elevation, and recent recharge probably suppressed most of the lake leakage below the shallow part of the surficial aquifer. Lateral lake outflow probably extends further out into the shallow part of the surficial aquifer during dry periods than during high recharge periods.

Isotopically heavy water increased with depth at the north and south Round Lake well nests, indicating greater amounts of lake leakage with depth (fig. 34). At the south well nest, water from the deepest surficial aquifer well (RL4) was isotopically heavier than the lake water (fig. 34 and app. F). Because the sampling period was wetter than normal, the isotopic composition of the lake should reflect these wetter conditions. The deeper water probably represents the isotopic composition of lake water during drier conditions, when evaporation was higher and dilution from rainwater was less evident. Water from the augmentation well also indicates lake leakage (fig. 33c). Thus, the lake is being augmented by a fraction of recirculated lake water, which has returned to the Upper Floridan aquifer.

The percentage of lake water $(x)$ in the ground water near Round Lake was calculated using $\delta^{18} \mathrm{O}$ as the conservative tracer in the following equation:

$$
x=\left(\delta_{g_{W}-} \delta_{m W}\right) /\left(\delta_{I W-} \delta_{m W}\right),
$$

where $\delta$ is the oxygen-18 value for the ground-water sample $\left(g_{W}\right)$, meteoric water $(m w)$, and lake water $\left(l_{W}\right)$. The volume-weighted mean $\delta^{18} \mathrm{O}$ value in rainwater was used to represent meteoric water (app. E). Two end members were used for lake water: (1) the mean $\delta^{18} \mathrm{O}$ value of water sampled from Round Lake, and (2) the $\delta^{18} \mathrm{O}$ value of the most enriched ground water at the south well nest, presumably representing lake water during a period that was drier than the sampling period. Results are shown in table 10.

Water from wells open to the upper part of the water table had 0 to 20 percent of the water from lake leakage, illustrating that little outflow from Round Lake moved laterally within the upper part of the surficial aquifer during this wet sampling period. Recent recharge during the sampling period probably suppressed most of the lake leakage in the upper part of the surficial aquifer. The percentage of lake leakage at the well nests increased with depth in the surficial aquifer, ranging from 48 to 100 percent. Water in the intermediate confining unit also had a large percentage of lake leakage (between 87 and 98 percent). Water from the
Table 10. Percentage of lake leakage in the surrounding ground-water system at Round Lake based on delta oxygen-18

[SA, surficial aquifer; wt, well completed in the water table; ICU, intermediate confining unit, UFA, Upper Floridan aquifer; gw, ground water; RL aug; Round Lake augmentation; $\delta^{18} \mathrm{O}$, delta oxygen-18]

\begin{tabular}{|c|c|c|c|c|c|}
\hline \multirow{2}{*}{$\begin{array}{c}\text { Well } \\
\text { name }\end{array}$} & \multirow{2}{*}{$\begin{array}{c}\text { Index } \\
\text { number }{ }^{1}\end{array}$} & \multirow{2}{*}{$\begin{array}{c}\text { Sample } \\
\text { date }\end{array}$} & \multirow[t]{2}{*}{ Aquifer } & \multicolumn{2}{|c|}{$\begin{array}{l}\text { Percentage o } \\
\text { lake water in }\end{array}$} \\
\hline & & & & $g w^{2}$ & $g w^{3}$ \\
\hline RL8 & 8 & 11/07/97 & SA, wt & 12 & 11 \\
\hline RL9 & 9 & $12 / 03 / 97$ & SA, wt & 20 & 18 \\
\hline RL11 & 11 & $12 / 03 / 97$ & SA, wt & 0 & 0 \\
\hline RL12 & 12 & $11 / 05 / 97$ & SA, wt & 0 & 0 \\
\hline RL6 & 6 & $11 / 04 / 97$ & SA, wt & 60 & 55 \\
\hline RL6 & 6 & 06/04/98 & SA, wt & 44 & 41 \\
\hline RL5 & 5 & $11 / 04 / 97$ & SA & 100 & 100 \\
\hline RL5 & 5 & 06/04/98 & SA & 84 & 77 \\
\hline RL4 & 4 & $11 / 05 / 97$ & SA & 100 & 100 \\
\hline RL4 & 4 & 06/04/98 & SA & 100 & 99 \\
\hline RL3 & 3 & $11 / 04 / 97$ & SA, wt & 0 & 0 \\
\hline RL3 & 3 & 06/02/98 & SA, wt & 0 & 0 \\
\hline RL2 & 2 & 11/03/97 & SA & 52 & 48 \\
\hline RL2 & 2 & 06/02/98 & SA & 0 & 0 \\
\hline RL1 & 1 & 11/03/97 & SA & 91 & 84 \\
\hline RL1 & 1 & 06/02/98 & SA & 64 & 59 \\
\hline RL23 & 23 & $11 / 04 / 97$ & SA & 99 & 91 \\
\hline RL23 & 23 & 06/04/98 & SA & 88 & 81 \\
\hline RL22 & 22 & 11/07/97 & ICU & 95 & 87 \\
\hline RL22 & 22 & 06/04/98 & $\mathrm{ICU}$ & 98 & 90 \\
\hline RL aug & 26 & $11 / 05 / 97$ & UFA & 73 & 67 \\
\hline RL aug & 26 & 07/10/98 & UFA & 65 & 59 \\
\hline
\end{tabular}

${ }^{1}$ Refer to index number in appendix A for well construction information and figure 5 for well locations.

${ }^{2}$ Using the average of sampled lake water $\mathrm{d}^{18} \mathrm{O}$ as the lake end member (negative numbers were set to zero).

${ }^{3} \mathrm{Using}$ the greatest $\mathrm{d}^{18} \mathrm{O}$ value in the ground water as the lake end member (negative numbers were set to zero).

Round Lake augmentation well contained between 59 and 73 percent lake leakage, which is relatively high considering dilution in this highly transmissive aquifer.

For more than 30 years, Round Lake has received approximately twice its lake volume per year from augmented ground water. The lake level is higher than the water table in the surficial aquifer, increasing lake leakage to the surficial aquifer, which subsequently recharges the Upper Floridan aquifer. Results from water-quality sampling indicate the influence of augmentation water on lake-water quality, particularly calcium and bicarbonate concentrations. Water from the surficial aquifer near the lake had elevated concentrations of calcium and bicarbonate, reflecting the influence of lake leakage on ground-water quality. 
The isotopic data confirm that lake leakage is significant in the Round Lake basin and water in the adjacent surficial aquifer consists of as much as 100 percent lake leakage. Furthermore, a large percentage of Round Lake augmentation water (up to 73 percent) consists of water that has been recirculated from the lake.

\section{SUMMARY AND CONCLUSIONS}

The hydrologic effects associated with augmenting a lake with ground water from the Upper Floridan aquifer were examined in northwest Hillsborough County, Florida, from June 1996 through May 1999. The study involved comparing the hydrogeology, ground-water flow patterns, water budgets, and waterquality characteristics of a lake that has been augmented for more than 30 years (Round Lake) with two nearby non-augmented lakes (Dosson Lake and Halfmoon Lake).

The three study lakes are small (11 to 33 acres), relatively shallow (average depth less than $10 \mathrm{ft}$ ), and presumably of sinkhole origin. The lakes are situated within a mantled karst terrain, where approximately $42 \mathrm{ft}$ of unconsolidated sand and clay sediments overlie an irregular limestone surface. The surficial aquifer is within the unconsolidated sediments and provides recharge to the lakes and the underlying Upper Floridan aquifer. The intermediate confining unit, which separates the two aquifers, controls the downward recharge to the Upper Floridan aquifer through localized breaches, or sand columns, within the clay confining unit. The Upper Floridan aquifer is highly productive, and three well fields in the study area withdraw large volumes of water from the aquifer.

Round Lake is in a more leakage-dominated hydrogeologic setting compared to the other study lakes. The intermediate confining unit is thin or highly breached at Round Lake, which leads to increased ground-water circulation and a better hydraulic connection with the Upper Floridan aquifer. In addition, Round Lake has the least amount of soft, organic lakebottom sediments, and the lake bottom has been dredged deeper and more extensively than the other study lakes, which may allow more leakage out of the lake bottom. Seismic data indicate that there is an apparent lack of continuity in the limestone surface beneath the lake, although the other lakes have other subsidence-related features in their sublake geology.
The area around Round Lake has experienced more sinkhole activity than the other study lakes. During the study, three sinkholes developed around the perimeter of the lake, which may have further disrupted the intermediate confining unit.

Ground-water flow patterns around Round Lake were considerably different than at the non-augmented lakes. Ground-water augmentation artificially raised the level of Round Lake about 2 to $3 \mathrm{ft}$ higher than the adjacent water table for most of the study. As a result, lake water recharged the surficial aquifer around the entire lake perimeter, except during very wet periods when ground-water inflow occurred around part of the lake perimeter. The non-augmented lakes typically had areas of ground-water inflow and areas of lake leakage around their perimeter. During wet periods, groundwater inflow typically occurred around the entire perimeter of the non-augmented lakes. Therefore, the area potentially contributing ground water to the nonaugmented lakes is much larger than for the augmented lake. Vertical head loss within the surficial aquifer was higher at Round Lake than the other study lakes, which is additional evidence of the limited confinement at Round Lake.

Annual and monthly ground-water outflow (lake leakage) was significantly higher at Round Lake than at the non-augmented lakes for the 3-year study period. Minimum estimates of the total annual ground-water inflow and outflow were made from the monthly net ground-water flows. Based on these minimum estimates, total annual ground-water outflow for Round Lake was more than 10 times higher than for the nonaugmented lakes. Ground-water inflow to Round Lake was less than 1 percent of total annual inflows, whereas augmentation water was 70 percent. In comparison, ground-water inflow averaged 23 and 40 percent of the total annual inflows at Halfmoon Lake and Dosson Lake, respectively. Local ground-water pumping, augmentation, and hydrogeologic factors are responsible for the higher net ground-water outflow at Round Lake. As a result of localized ground-water pumping, the head difference between the lake and the Upper Floridan aquifer increases, which increases lake leakage and results in lowered lake levels. Augmenting the lake further increases the head difference between the lake, the water table, and the Upper Floridan aquifer, which results in an increase in lateral and vertical outflow from the lake. The lack of confinement or breaches in the intermediate confining unit facilitates the downward movement of this augmented lake water back into the Upper Floridan aquifer. 
A comparison of the water quality at the three lakes indicates that Round Lake is strongly influenced by the addition of large quantities of calcium-bicarbonate enriched augmentation water. Round Lake had the highest alkalinity, calcium and dissolved oxygen concentrations, $\mathrm{pH}$ values, and specific conductance. Round Lake also had the highest clarity, which is probably due to the short lake-water residence time and large input of relatively low nutrient ground water. The lake water at Round Lake was generally saturated to supersaturated with respect to calcite, and was undersaturated when augmentation was low after high rainfall periods. The lake water at the non-augmented lakes was undersaturated with calcite.

Round Lake had the largest accumulation of calcium carbonate and the highest radium-226 activity levels in the lake sediments. The calcium carbonate accumulation is from a combination of calcium carbonate precipitate and the growth and accumulation of macrophytes, such as Nitella sp. and carbonate-rich mollusks, such as Planorbella sp., which both thrive in the high-alkalinity lake water. The high radium-226 levels ( $\left.27 \mathrm{dpm} \mathrm{g}^{-1}\right)$ in lake sediments at Round Lake can be atrributed to augmenting the lake with ground water from the Upper Floridan aquifer. Although this ground water has relatively low levels of radium-226 (5.8 dpm per liter), the large volumes of ground water added to the lake for more than 30 years have caused radium-226 to accumulate in the sediments and lake biota.

The Round Lake basin had higher calcium and bicarbonate concentrations in the surficial aquifer than at the non-augmented lakes. These high concentrations are due to large volumes of calcium-bicarbonate enriched lake water that flows out laterally into the surficial aquifer. Deuterium and oxygen-18 data indicate that ground water in near-shore well nests at Round Lake consists of as much as 100 percent lake leakage, and that the augmentation water has a high fraction of recirculated lake water (between 59 and 73 percent lake leakage).

The hydrology and chemistry of Round Lake have been substantially altered by ground-water augmentation. Round Lake is in a leakage-dominated setting because the intermediate confining unit is thin or highly breached, which increases the potential for vertical ground-water flow. When the lake level is augmented higher than the adjacent water table, large volumes of calcium-bicarbonate enriched lake water flows out laterally and downward to the underlying aquifers. Mixing of lake leakage with naturally acidic waters of the surficial aquifer results in ground water becoming undersaturated with respect to calcite as it moves downward to the Upper Floridan aquifer. Consequently, this large volume of recirculated augmentation water is capable of dissolving calcite in the limestone aquifer. Therefore, as a result of ground-water augmentation at Round Lake, the volume of groundwater flow within the aquifer system has increased, which has increased the potential for karst activity (limestone dissolution, subsidence, and sinkhole formation).

\section{REFERENCES}

Alhajjar, B.J., Chesters, Gordon, and Harkin, J.M., 1990, Indicators of chemical pollution from septic systems: Ground Waters, v. 28, p. 559-568.

Alhajjar, B.J., Harkin, J.M., and Chesters, Gordon, 1989, Detergent formula and characteristics of waste-water in septic tanks: Journal of Water Pollution Control Fed., v. 61 , p. 605-613.

Allen, M.S., 1999, Assessment of fish assemblages in Lakes Dosson, Halfmoon, and Round in Hillsborough County, Florida: January, 1999: Brooksville, Southwest Florida Water Management District, 38 p.

Allen, R.G., Pereira, L.S., Rases, D., and Smith, M., 1998, Guidelines for computing crop water requirements, Food and Agriculture Organization Irrigation and Drainage Paper 56: FAO of the United Nations, Rome, 282 p.

Belanger, T.V., and Kirkner, R.A., 1994, Groundwater/surface water interaction in a Florida augmentation lake, Lake and reservoir management: v. 8, no. 2, p. 165-174.

Brater, E.F., and King, H.W., 1976, Handbook of hydraulics: New York, McGraw-Hill, 584 p.

Brenner, M., and Whitmore, T.J., 1999, Paleolimnological reconstruction of water quality for Lakes Dosson, Halfmoon, and Round in Hillsborough County, Florida: January, 1999: Southwest Florida Water Management District, 158 p.

Brenner, M., Peplow, A.J., and Schelske, C.L., 1994, Disequilibrium between ${ }^{226} \mathrm{Ra}$ and supported ${ }^{210} \mathrm{~Pb}$ dates in a sediment core from a shallow Florida lake: Limnology and Oceanography, v. 39, p. 1222-1227.

Brenner, M., Schelske, C.L., and Whitener, T.J., 1997, Radium-226 stratigraphy in Florida lake sediments as an indicator of human disturbance: International Association of Theoretical and Applied Limelight, v. 26, p. 809-813. 
Brenner, M., Smoak, J.M., Allen, M.S., Schelske, C.L., Leeper, D.A., 2000, Biological accumulation of ${ }^{226} \mathrm{Ra}$ in a ground-water augmented Florida lake: Limnology and Oceanography, v. 43, no. 3, p. 710-715.

Brooks, H.K., 1981, Guide to the physiographic provinces of Florida: Gainesville, Florida Cooperative Extension Service, Institute of Food and Agricultural Sciences, University of Florida, $11 \mathrm{p}$.

Carr, W.J., and Alverson, D.C., 1959, Stratigraphy of middle Tertiary rocks in part of west-central Florida: U.S. Geological Survey Bulletin 1092, $111 \mathrm{p}$.

Cherry, R.N., Stewart, J.W., and Mann, J.A., 1970, General hydrology of the middle gulf area, Florida: Tallahassee, Florida Department National Resources, Bureau of Geology Report of Investigation, no. 56, 96 p.

Chow, V.T., 1959, Open channel hydraulics: New York, McGraw-Hill, $680 \mathrm{p}$.

Coffin J.W., and Fletcher, W.L., 1999a, Water resources data for Florida water year 1998, v. 3A. Southwest Florida surface water: U.S. Geological Survey Water-Data Report FL-98-3A, 366 p.

---- 1999b, Water resources data for Florida water year 1998 , v. 3B. Southwest Florida ground water: U.S. Geological Survey Water-Data Report FL-98-3B, 323 p.

----- 2000a, Water resources data for Florida water year 1999, v. 3A. Southwest Florida surface water: U.S. Geological Survey Water-Data Report FL-99-3A, 373 p.

---- 2000b, Water resources data for Florida water year 1999, v. 3B. Southwest Florida ground water: U.S. Geological Survey Water-Data Report FL-99-3B, 207 p.

Cowell, B.C., 1999, Benthic invertebrates of three lakes in northwest Hillsborough County, Florida (Lake Dosson, Halfmoon Lake, and Round Lake), November, 1999: Brooksville, Southwest Florida Water Management District, $52 \mathrm{p}$.

Craig, H., 1961, Isotopic variations in natural water: Science, v. 133, p. 1702-1703.

Deevey, E.S., Jr., 1988, Estimation of downward leakage from Florida lakes: Limnology and oceanography, v. 33, no. 6 , pt. 1 , p. $1308-1320$.

Dinçer, T., 1968, The use of oxygen 18 and deuterium concentrations in the water balance of lakes; WaterResources Research, v. 4, p. 1289-1306.

Dooris, P.M., Dooris, G.M., and Martin, D.F., 1982, Phytoplankton responses to ground water addition in central Florida lakes: Water Resources Bulletin 18, p. 335-337.

Drever, J.I., 1982, The geochemistry of natural waters: Englewood Cliffs, N.J., Prentice-Hall, 388 p.

Driscoll, F.G., 1986, Groundwater and wells: St. Paul, Minn., Johnson Filtration Systems Inc., 1089 p.

Duerr, A.D., and Torres, A.E., 2000, Potentiometric surface of the Upper Floridan aquifer, west-central Florida, May 1999: U.S. Geological Survey Open-File Report 00-72, 1 sheet.
Farnsworth, R.K., Thompson, E.S., and Peck, E.L., 1982, Evaporation atlas for the contiguous 48 United States: Asheville, N.C., National Oceanic and Atmospheric Administration Technical Report NWS 33, 26 p., 4 sheets.

Freeze, R.A., and Cherry, J.A., 1979, Groundwater: Englewood Cliffs, N.J., Prentice-Hall, 604 p.

German, E.R., 1997, Analysis of nonpoint-source groundwater contamination in relation to land use: Assessment of nonpoint-source contamination in central Florida: U.S. Geological Survey Water-Supply Paper 2381-F, $60 \mathrm{p}$.

Gillen, D.F., 1996, Determination of roughness coefficients for streams in west-central, Florida: U.S. Geological Survey Open-File Report 96-226, 93 p.

Green, R., Arthur, J.D., and DeWitt, D., 1995, Lithostratigraphic and hydrostratigraphic cross sections through Pinellas and Hillsborough Counties, southwest Florida: Tallahassee, Florida Geological Survey, Open File Report 61, 26 p.

Hakanson, L., and Jansson, M., 1983, Principles of lake sedimentology: New York, Springer-Verlag, 316 p.

Hem, J.D., 1985, Study and interpretation of the chemical characteristics of natural water ( $3 \mathrm{~d}$ ed.): U.S. Geological Survey Water-Supply Paper 2254, 263 p.

Huber, W.C., Brezonik, P.L., Henery, J.P., Dickinson, R.E., Preston, S.D., Dwornik, D.S., and Demaio, M.A., 1982, A classification of Florida lakes: Gainesville, Water Resources Research Center, University of Florida, Publication No. 72, 547 p.

Jenson, M.E., 1974, Consumptive use of water and irrigation water requirements: American Society of Civil Engineers, $215 \mathrm{p}$.

Kaufmann, R.F., and Bliss, J.D., 1977, Effects of phosphate mineralization and the phosphate industry on radium226 in ground water of central Florida: Las Vegas, EPA Office of Radiation Programs, U.S. Environmental Protection Agency Final Report EPA/520-6-77-010.

Kindinger, J.L., Davis, J.B., and Flocks, J.G., 1994, Highresolution single-channel seismic-reflection surveys of Orange Lake and other selected sites of north-central Florida: U.S. Geological Survey Open-File Report 94-616, $48 \mathrm{p}$.

Kohler, M.A., Nordenson, T.J., and Baker, D.R., 1959, Evaporation maps for the United States: U.S. Weather Bureau Technical Paper 37, 13 p., 5 plates.

Krabbenhoft, D.P., Bowser, C.J., Anderson, M.P., and Valley, J.W., 1990, Estimating groundwater exchange with lakes, 1 . The stable isotope mass balance method: Water Resources Research, v. 26, p. 2445-2453. 
Krabbenhoft, D.P., Bowser, C.J., Kendall, C., and Gat, J.R., 1994, Use of oxygen-18 and deuterium to assess the hydrology of groundwater-lake systems, in Baker, L.A., ed., Environmental Chemistry of Lakes and Reservoirs: American Chemical Society, p. 67-90.

Langevin, C.D., Thompson, T., LaRoche, J., Albury, C.W., Shoemaker, W.B., and Stewart, M.T., 1998, Development of a conceptual hydrogeologic model from field and laboratory data, phase II results, North Lakes wetland project, Hillsborough County, Florida, May 1998: Brooksville, Southwest Florida Water Management District, $72 \mathrm{p}$.

Lee, T.M., 2000, The effects of near-shore recharge on groundwater interactions with a lake in karst terrain: Water Resources Research, v. 36, no. 8, p. 2167-2182.

----- 2002, Factors affecting the ground-water exchange and catchment size for Florida lakes in mantled karst terrain: U.S. Geological Survey Water-Resources Investigation Report 02-4033.

Lee, T.M., Adams, D.B., Tihansky, A.B., and Swancar, Amy, 1991, Methods, instrumentation, and preliminary evaluation of data for the hydrologic budget assessment of Lake Lucerne, Polk County, Florida: U.S. Geological Survey Water-Resources Investigation 90-4111, 42 p.

Lee, T.M., and Swancar, Amy, 1997, The influence of evaporation, ground water and uncertainty in the hydrologic budget of Lake Lucerne, a seepage lake in Polk County, Florida: U.S. Geological Survey Water-Supply Paper 2439, $61 \mathrm{p}$.

Lewelling, B.R., Tihansky, A.B., and Kindinger, J.L., 1998, Assessment of the hydraulic connection between ground water and the Peace River, west-central Florida: U.S. Geological Survey Water-Resources Investigation 97-4211, 96 p.

Locker, S.D., Brooks, G.R., and Doyle, L.J., 1988, Results of a seismic-reflection investigation and hydrogeologic implications for Lake Apopka, Florida: Center for Nearshore Marine Science, Final report to the St. John's Water Management District, 39 p.

Lopez, M.A., and J.D., Fretwell, 1992, Relation of change in water levels in surficial and Upper Floridan aquifers and lake stage to climatic conditions and well-field pumpage in northwest Hillsborough, northeast Pinellas, and south Pasco Counties, Florida: U.S. Geological Survey WaterResources Investigations Report 91-4148, 94 p.

Martin, D.F., Victor, D.M., Dooris, P.M., 1976, Effects of artificially introduced ground water on the chemical and biochemical characteristics of six Hillsborough County (Florida) lakes: Water Research Journal 10, p. 65-69.

Menke, C.G., Meredith, E.W., and Wetterhall, W.S., 1961, Water resources of Hillsborough County, Florida: Tallahassee, Florida Geological Survey Report Investigation 25, $101 \mathrm{p}$.
Miller, J.A., 1986, Hydrogeologic framework of the Floridan aquifer system in Florida and in parts of Georgia, Alabama, and South Carolina: U.S. Geological Survey Water-Supply Paper 1403-B, 91 p.

Moore, C.H., 1989, Carbonate diagenesis and porosity: Amsterdam, Elsevier Science Publishers B.V., 338 p.

Newton, J.G., 1986, Development of sinkholes resulting from man's activities in the Eastern United States: U.S. Geological Survey Circular 968, 54 p.

Nixon, P.R., and Lawless, G.P., 1968, Advective influences on the reduction of evapotranspiration in a coastal environment: Lompoc, Calif., U.S. Soil and Water Conservation Research Station, v. 4, no. 1.

Payton, C.E., ed., 1977, Seismic stratigraphy--Applications to hydrocarbon exploration: Tulsa, Okla., American Association of Petroleum Geologist Memoir 26, 516 p.

Philander, S.G.H., 1990, El Niño, La Niña and the Southern Oscillation: San Diego, Calif., Academic Press, 289 p.

Plummer, L.N., Prestemon, E.C., and Parkhurst, D.L., 1994, An interactive code (NETPATH) for modeling net geochemical reactions along a flow path: U.S. Geological Survey Water-Resources Investigations Report 94-4169, 130 p.

Sacks, L.A., Lee, T.M., and Radell, M.J., 1994, Comparison of energy-budget evaporation losses from two morphometrically different seepage lakes: Journal of Hydrology, v. 156, p. 311-334.

Sacks, L.A., Lee, T.M., and Tihansky, A.B., 1992, Hydrologic setting and preliminary data analysis for the hydrologic-budget assessment of Lake Barco, an acidic seepage lake in Putnam County, Florida: U.S. Geological Survey Water-Resources Investigation 91-4180, $28 \mathrm{p}$.

Sacks, L.A., Swancar, Amy, and Lee, T.M., 1998, Estimating ground-water exchange with lakes using water-budget and chemical mass-balance approaches for ten lakes in ridge areas of Polk and Highlands Counties, Florida: U.S. Geological Survey Water-Resources Investigations Report 98-4133, 52 p.

Shock, E.L., and Wilson, W.L., 1996, Sinkhole development in Hillsborough County, Florida: Subsurface Evaluations, Inc., 56 p., 3 app., 1 disk.

Sinclair, W.C., 1974, Hydrogeologic characteristics of the surficial aquifer in northwest Hillsborough County, Florida, U.S. Geological Survey Information Circular no. 86,98 p.

----- 1977, Experimental study of artificial recharge alternatives in northwest Hillsborough County, Florida, U.S. Geological Survey Water-Resources Investigations 77-13, $52 \mathrm{p}$.

1982, Sinkhole development resulting from groundwater development in the Tampa area, Florida: U.S. Geological Survey Water-Resources Investigations Report 81-50, 19 p. 
Sinclair, W.C., Knutilla, R.L., Gilboy, A.E., and Miller, R.L., 1985, Types, features, and occurrence of sinkholes in the karst of west-central Florida: U.S. Geological Survey Water Resources Investigations Report 85-4126, $81 \mathrm{p}$.

Sinclair, W.C., and Stewart, J.W., 1985, Sinkhole type, development, and distribution in Florida: Tallahassee, Florida Bureau of Geology Map Series no. 110, 1 sheet.

Southeastern Geological Society, 1986, Hydrogeological units of Florida: Tallahassee, Florida Bureau of Geology Special Publication 28, $9 \mathrm{p}$.

Southwest Florida Water Management District, 1994, Aquifer characteristics within the Southwest Florida Water Management District: Southwest Florida Water Management District, Brooksville, Florida, 111 p.

----- 1996, Northern Tampa Bay water resources assessment project, volume 1, surface-water/ground-water interrelationships: Southwest Florida Water Management District, Brooksville, Florida.

---- 1999, Special monthly pumpage report Tampa Bay water's consolidated permit: Southwest Florida Water Management District, Brooksville, Florida, December 1999, 64 p.

Stauffer, R.E., 1991, Effects of citrus agriculture on ridge lakes in central Florida: Water Air and Soil Pollution, v. 59 , p. $125-144$.

Stewart, J.W., 1968, Hydrologic effects of pumping from the Floridan aquifer in northwest Hillsborough, northeast Pinellas, and southwest Pasco Counties, Florida: U.S. Geological Survey Open-File Report, 241 p.

Stewart, J.W., and Hughes, G.H., 1974, Hydrologic consequences of using ground water to maintain lake levels affected by water wells near Tampa, Tallahassee, Florida: Florida Bureau of Geology Report of Investigation no. $74,41 \mathrm{p}$.

Stewart, M.T., and Parker, J., 1992, Localization and seasonal variation of recharge in a covered karst aquifer system, Florida, USA, in Paloc, H., and Back, W., eds., Hydrogeology of Selected Karst Regions: Hannover, Verlag Heinz Heise, 13 p.
Swancar, A., Lee, T.M., and O'Hare, T.M., 2000, Hydrogeologic setting, water budget, and preliminary analysis of ground-water exchange at Lake Starr, a seepage lake in Polk County, Florida: U.S. Geological Survey WaterResources Investigations Report 00-4030, 66 p.

Tihansky, A.B., 1999, Sinkholes, west-central Florida--A link between surface water and ground water, in Calloway, Devin, Jones, D.R., and Ingebritsen, S.E., eds., Land subsidence in the United States: U.S. Geological Survey, Circular 1182, p. 121-141.

Tihansky, A.B., Arthur, J.D., and DeWitt, D.J., 1996, Sublake geologic structure from high-resolution seismicreflection data from four sinkhole lakes in the Lake Wales Ridge, central Florida: Open-File Report 96-224, $72 \mathrm{p}$.

Wetzel, R.G., 1975, Limnology: Philadelphia, W.B. Saunders Company, $743 \mathrm{p}$.

White, W.A., 1970, Geomorphology of the Florida Peninsula: Tallahassee, Florida Geological Survey Bulletin 51, $164 \mathrm{p}$.

Wilde, F.D., Radtke, D.B., Gibs, J., and Iwatsubo, R.T., 1998, National field manual for the collection of waterquality data: U.S. Geological Survey Techniques of Water-Resources Investigations, book 9, chap. A1-A9.

Winter, T.C., 1981, Uncertainties in estimating the water balance of lakes: Water Resources Bulletin, v. 17, no. 1, p. 82-115.

----- 1986, Effect of ground-water recharge on configuration of the water table beneath sand dunes and on seepage in lakes in the sandhills of Nebraska, U.S.A.: Journal of Hydrology, v. 86, p. 221-237.

Winter, T.C., Harvey J.W., Franke, O.L., and Alley, W.M., 1998, Ground water and surface water, a single resource: U.S. Geological Survey Circular 1139, 79 p.

Winter, T.C., and Rosenberry, D.O., 1995, Evaluation of 11 equations for determining evaporation for a small lake in the north-central United States: Water Resources Research, v. 31, no. 4, p. 983-993.

Wolansky, R.M., and Corral, M.A., Jr., 1985, Aquifer tests in west-central Florida, 1952-76: U.S. Geological Survey Water-Resources Investigations Report 84-4044, 127 p. 


\section{Appendixes}


Appendix A. Well characteristics and data summary for wells in the study area

[Well name: DL, Dosson Lake; HML, Halfmoon Lake; RL, Round Lake; Total cased interval: --, unknown casing depth; Hydrogeologic unit: SA, surficial aquifer; ICU, intermediate confining unit; UFA, Upper Floridan aquifer; Data summary: CWR, continuous water-level recorder; FM, flowmeter; GS, geophysical survey; QW, quality of water; SSS, split-spoon sample; WL, monthly water level]

\begin{tabular}{|c|c|c|c|c|c|c|}
\hline $\begin{array}{c}\text { Index } \\
\text { number }\end{array}$ & $\begin{array}{l}\text { Identification } \\
\text { number }\end{array}$ & Well name & $\begin{array}{l}\text { Total } \\
\text { depth } \\
\text { (feet) }\end{array}$ & $\begin{array}{c}\text { Total cased } \\
\text { interval } \\
\text { (feet) }\end{array}$ & $\begin{array}{l}\text { Hydro- } \\
\text { geologic } \\
\text { unit }\end{array}$ & Data summary \\
\hline 1 & 280718082295801 & RL1 North Int Nest & 17.0 & 15.0 & SA & QW, WL \\
\hline 2 & 280718082295802 & RL2 North Shallow Nest & 12.4 & 10.0 & SA & QW, WL \\
\hline 3 & 280718082295803 & RL3 WT Nest & 10.6 & 1.0 & SA & QW, WL \\
\hline 4 & 280710082295901 & RL4 South Deep Nest & 20.1 & 17.2 & SA & QW, WL \\
\hline 5 & 280710082295902 & RL5 South Int Nest & 14.5 & 12.1 & SA & QW, WL \\
\hline 6 & 280710082295903 & RL6 South WT Nest & 12.5 & 2.0 & SA & QW, WL \\
\hline 7 & 280706082300401 & RL7 Berger Road & 18.2 & 2.5 & SA & QW, WL \\
\hline 8 & 280707082300801 & RL8 Berger Road & 18.3 & 2.6 & SA & QW, WL \\
\hline 9 & 280714082300701 & RL9 Kelly Residence & 18.2 & 2.7 & SA & $\mathrm{QW}, \mathrm{WL}$ \\
\hline 10 & 280718082300801 & RL10 Little Road & 18.2 & 2.5 & SA & WL \\
\hline 11 & 280721082300401 & RL11 Little Road & 18.2 & 2.5 & SA & QW, WL \\
\hline 12 & 280713082295401 & RL12 Linda Vista & 13.0 & 2.5 & SA & QW, WL \\
\hline 13 & 280648082300701 & RL13 Hartline Lot & 13.0 & 3.0 & SA & WL \\
\hline 14 & 280724082293301 & RL14 Little Road & 13.0 & 3.0 & SA & WL \\
\hline 15 & 280740082295401 & RL15 Van Dyke 2 & 13.0 & 3.0 & SA & WL \\
\hline 16 & 280744082300801 & RL16 Dale Mabry & 13.0 & 3.0 & SA & WL \\
\hline 17 & 280707082292701 & RL17 Berger Road & 13.0 & 3.0 & SA & WL \\
\hline 18 & 280638082293201 & RL18 Golf Course & 12.5 & 2.5 & SA & WL \\
\hline 19 & 280646082295101 & RL19 Lakeview Drive & 13.5 & 1.0 & SA & WL \\
\hline 20 & 280718082300001 & RL20 McMannus Dock & 6.5 & 1.0 & SA & WL \\
\hline 21 & 280713082300601 & RL21 Kelly Residence & 7.0 & 2.0 & SA & WL \\
\hline 22 & 280718082295804 & RL22 North ICU Nest & 45.0 & 42.0 & ICU & GS, QW, SSS, WL \\
\hline 23 & 280718082295805 & RL23 North Deep Nest & 27.5 & 24.5 & SA & CWR, GS, SSS, QW \\
\hline 24 & 280726082300001 & RL24 Little Road & 20.0 & 3.0 & SA & WL \\
\hline 25 & 280656082295501 & RL25 Heatherwoods & 16.1 & 1.3 & SA & WL \\
\hline 26 & 280718082295601 & RL Augmentation & 395.0 & 74.0 & UFA & FM, QW, WL \\
\hline 27 & 280716082295701 & Dewey Thompson Deep & 97.0 & -- & UFA & WL \\
\hline 28 & 280717082295401 & Dewey Thompson Shallow & 11.5 & -- & SA & WL \\
\hline 29 & 280659082294302 & Berger Deep & 134.0 & 44.0 & UFA & CWR \\
\hline 30 & 280659082294303 & Berger Shallow & 20.0 & 19.0 & SA & WL \\
\hline 31 & 280706082300301 & Rusty at Berger Road & 20.6 & -- & SA & WL \\
\hline 32 & 280739082294202 & USGS Van Dyke & 22.0 & 18.0 & SA & WL \\
\hline 33 & 280530082325601 & HML1 5630 Rawis & 12.4 & 1.8 & SA & $\mathrm{QW}, \mathrm{WL}$ \\
\hline 34 & 280557082324501 & HML2 HML Road & 12.4 & 1.8 & SA & QW, WL \\
\hline 35 & 280552082325403 & HML3 Deep Nest & 22.1 & 19.6 & SA & QW, WL \\
\hline 36 & 280552082325404 & HML4 Int Nest & 12.5 & 10.0 & SA & QW, WL \\
\hline 37 & 280546082324301 & HML5 Rye Road & 15.3 & 2.4 & SA & WL \\
\hline 38 & 280544082324703 & HML6 Wt Nest & 12.0 & 1.4 & SA & $\mathrm{QW}, \mathrm{WL}$ \\
\hline 39 & 280544082324702 & HML7 Int Nest & 10.6 & 8.1 & SA & QW, WL \\
\hline 40 & 280544082324701 & HML8 Deep Nest & 22.2 & 18.9 & SA & QW, WL \\
\hline 41 & 280600082325901 & HML9 Dew Point & 12.5 & 1.9 & SA & QW, WL \\
\hline 42 & 280557082330701 & HML9A Timberwood & 13.0 & 3.0 & SA & QW, WL \\
\hline 43 & 280551082325201 & HML10 Willowdale & 12.2 & 2.1 & SA & QW, WL \\
\hline 44 & 280550082330201 & HML11 Willowdale & 10.0 & 1.5 & SA & WL \\
\hline 45 & 280541082330201 & HML12 Willowdale & 13.0 & 3.0 & SA & QW, WL \\
\hline 46 & 280539082324301 & HML13 Pappy’s Grove & 11.2 & 2.2 & SA & WL \\
\hline 47 & 280552082324501 & HML14 Rye Road & 12.0 & 2.0 & SA & WL \\
\hline
\end{tabular}


Appendix A. Well characteristics and data summary for wells in the study area (Continued)

[Well name: DL, Dosson Lake; HML, Halfmoon Lake; RL, Round Lake; Total cased interval: --, unknown casing depth; Hydrogeologic unit: SA, surficial aquifer; ICU, intermediate confining unit; UFA, Upper Floridan aquifer; Data summary: CWR, continuous water-level recorder; FM, flowmeter; GS, geophysical survey; QW, quality of water; SSS, split-spoon sample; WL, monthly water level]

\begin{tabular}{|c|c|c|c|c|c|c|}
\hline $\begin{array}{l}\text { Index } \\
\text { number }\end{array}$ & $\begin{array}{l}\text { Identification } \\
\text { number }\end{array}$ & Well name & $\begin{array}{l}\text { Total } \\
\text { depth } \\
\text { (feet) }\end{array}$ & $\begin{array}{c}\text { Total cased } \\
\text { interval } \\
\text { (feet) }\end{array}$ & $\begin{array}{l}\text { Hydro- } \\
\text { geologic } \\
\text { unit }\end{array}$ & Data summary \\
\hline 48 & 280538082330801 & HML15 Timberwood & 13.5 & 1.0 & SA & WL \\
\hline 49 & 280624082323901 & HML16 Wilcox Road & 12.5 & 2.5 & SA & WL \\
\hline 50 & 280626082330401 & HML17 Tobacco Road & 12.5 & 2.5 & SA & WL \\
\hline 51 & 280517082331501 & HML18 Trail Creek Place & 12.5 & 2.5 & SA & WL \\
\hline 52 & 280507082324901 & HML19 Shaw Road & 12.5 & 2.5 & SA & WL \\
\hline 53 & 280519082322601 & HML20 Hutchinson Road & 12.5 & 2.5 & SA & WL \\
\hline 54 & 280626082331701 & HML21 Offenhaur Road & 12.5 & 2.5 & SA & WL \\
\hline 55 & 280537082333201 & HML22 Bellamy Road & 12.5 & 2.5 & SA & WL \\
\hline 56 & 280504082333301 & HML23 Bellamy Road & 12.5 & 2.5 & SA & WL \\
\hline 57 & 280552082325401 & HML 24 Hutchinson & 6.0 & 1.0 & SA & QW, WL \\
\hline 58 & 280550082325501 & HML25 Willowdale & 6.0 & 1.0 & SA & WL \\
\hline 59 & 280558082330301 & HML26 HML Road & 5.0 & 1.0 & SA & WL \\
\hline 60 & 280540082325601 & HML27 5637 Rawls & 5.5 & .5 & SA & WL \\
\hline 61 & 280558082325501 & HML28 5704 HML Road & 3.3 & .5 & SA & WL \\
\hline 62 & 280554082324901 & HML29 5616 HML Road & 4.0 & .5 & SA & WL \\
\hline 63 & 280544082324704 & HML30 ICU Nest & 41.0 & 37.0 & $\mathrm{ICU}$ & GS, QW, SSS, WL \\
\hline 64 & 280544082324705 & HML31 UFA Nest & 100.0 & 50.0 & UFA & GS, QW, SSS, WL \\
\hline 65 & 280623082321401 & HML33 Wilcox Road & 13.5 & 1.0 & SA & WL \\
\hline 66 & 280548082322601 & HML34 Country Park & 13.5 & 1.0 & SA & WL \\
\hline 67 & 280531082320301 & HML35 Rawls & 13.2 & 1.5 & SA & WL \\
\hline 68 & 280552082325401 & HML59 UFA Nest & 60.0 & 49.0 & UFA & CWR, QW \\
\hline 69 & 280552082325402 & HML60 WT Nest & 20.0 & 3.0 & SA & CWR, QW \\
\hline 70 & 280551082324001 & HML Augmentation & 850.0 & 210.0 & UFA & QW, WL \\
\hline 71 & 280622082325401 & Northwest Elementary & 300.0 & -- & UFA & WL \\
\hline 72 & 280600082333001 & RMP5-D WCRWSA & 150.0 & -- & UFA & WL \\
\hline 73 & 280720082313901 & DL1 Marsh UFA NestUFA & 75.0 & 60.0 & UFA & CWR, GS, QW, SSS \\
\hline 74 & 280720082313902 & DL2 Marsh ICU Nest & 39.0 & 35.0 & $\mathrm{ICU}$ & GS, QW, SSS, WL \\
\hline 75 & 280720082313903 & DL3 Marsh Int Nest & 14.8 & 10.0 & SA & CWR, QW \\
\hline 76 & 280720082313904 & DL4 Marsh Deep Nest & 21.0 & 18.5 & SA & QW, WL \\
\hline 77 & 280720082313905 & DL5 Marsh Wt Nest & 10.0 & 10.0 & SA & WL \\
\hline 78 & 280722082314601 & DL6 Marsh West Monitor & 12.0 & 4.3 & SA & WL \\
\hline 79 & 280725082313501 & DL7 Marsh East Monitor & 50.0 & -- & UFA & WL \\
\hline 80 & 280728082314501 & DL8 Rankin property & 12.5 & 2.5 & SA & WL \\
\hline 81 & 280728082313701 & DL9 Rankin property & 13.5 & 3.0 & SA & WL \\
\hline 82 & 280739082313901 & DL10 Van Dyke Road & 12.5 & 2.5 & SA & WL \\
\hline 83 & 280733082313802 & DL11 Van Dyke Deep Nest & 20.0 & 17.5 & SA & WL \\
\hline 84 & 280733082313803 & DL12 Van Dyke Int Nest & 13.0 & 11.0 & SA & WL \\
\hline 85 & 280733082313801 & DL13 Van Dyke Wt Nest & 13.0 & 3.0 & SA & WL \\
\hline 86 & 280717082313601 & DL14 Taylorville Monitor & 12.5 & 2.5 & SA & WL \\
\hline 87 & 280738082312901 & DL15 Darby Lane & 14.0 & 3.5 & SA & WL \\
\hline 88 & 280733082312801 & DL17 Darby Lane & 13.0 & 3.0 & SA & WL \\
\hline 89 & 280730082312901 & DL18 Darby Lane & 13.0 & 3.0 & SA & WL \\
\hline 90 & 280726082313101 & DL19 Darby Lane & 6.4 & 1.4 & SA & QW, WL \\
\hline 91 & 280724082312901 & DL20 Thomas Residence & 6.6 & 1.6 & SA & QW, WLWL \\
\hline 92 & 280727082311901 & DL21 Darby Lane & 12.5 & 2.5 & SA & WL \\
\hline 93 & 280723082311801 & DL22 Darby LaneDarb Lane & 12.2 & 2.2 & SA & WL \\
\hline 94 & 280716082311801 & DL23 Darby Lane & 12.5 & 2.5 & SA & WL \\
\hline
\end{tabular}


Appendix A. Well characteristics and data summary for wells in the study area (Continued)

[Well name: DL, Dosson Lake; HML, Halfmoon Lake; RL, Round Lake; Total cased interval: --, unknown casing depth; Hydrogeologic unit: SA, surficial aquifer; ICU, intermediate confining unit; UFA, Upper Floridan aquifer; Data summary: CWR, continuous water-level recorder; FM, flowmeter; GS, geophysical survey; QW, quality of water; SSS, split-spoon sample; WL, monthly water level]

\begin{tabular}{|c|c|c|c|c|c|c|}
\hline $\begin{array}{c}\text { Index } \\
\text { number }\end{array}$ & $\begin{array}{l}\text { Identification } \\
\text { number }\end{array}$ & Well name & $\begin{array}{l}\text { Total } \\
\text { depth } \\
\text { (feet) }\end{array}$ & $\begin{array}{c}\text { Total cased } \\
\text { interval } \\
\text { (feet) }\end{array}$ & $\begin{array}{l}\text { Hydro- } \\
\text { geologic } \\
\text { unit }\end{array}$ & Data summary \\
\hline 95 & 280714082311801 & DL24 Darby Lane & 12.8 & 2.8 & SA & WL \\
\hline 96 & 280715082313301 & DL25 Dosson Lake SW & 7.0 & 2.0 & SA & QW, WL \\
\hline 97 & 280730082313201 & DL26 Dosson Lake NE & 7.0 & 2.0 & SA & QW, WL \\
\hline 98 & 280729082313501 & DL27 Dosson Lake NW & 7.0 & 2.0 & SA & QW, WL \\
\hline 99 & 280715082313001 & DL28 Dosson Lake SE & 4.5 & 1.0 & SA & WL \\
\hline 100 & 280726082310001 & DL29 Whirly Road & 13.5 & 1.0 & SA & WL \\
\hline 101 & 280714082310601 & DL30 Scott Road & 13.5 & 1.0 & SA & WL \\
\hline 102 & 280659082310101 & DL31 Whirly Road & 13.2 & 1.0 & SA & WL \\
\hline 103 & 280702082312501 & DL32 Whirly Road & 11.5 & 1.0 & SA & WL \\
\hline 104 & 280814082313201 & DL33 Horse Farm Road & 13.0 & 3.0 & SA & WL \\
\hline 105 & 280747082312501 & DL34 Horse Farm Road & 13.6 & 1.0 & SA & WL \\
\hline 106 & 280721082320001 & DL35 Lakeshore Road & 14.3 & 1.0 & SA & WL \\
\hline 107 & 280710082320001 & DL36 Taylor Road & 13.5 & 1.5 & SA & WL \\
\hline 108 & 280712082314801 & DL37 Taylor Road & 14.0 & 1.0 & SA & WL \\
\hline 109 & 280725082321401 & DL38 Lakeside Road & 13.0 & 3.0 & SA & WL \\
\hline 110 & 280707082322601 & DL39 Lakeside Road & 12.5 & 2.0 & SA & WL \\
\hline 111 & 280709082324601 & DL40 Storm Road & 14.5 & 4.5 & SA & WL \\
\hline 112 & 280734082323701 & DL41 Tobacco Road & 12.0 & 2.0 & SA & WL \\
\hline 113 & 280734082313301 & Goodwin at Darby Lane & 62.5 & -- & UFA & WL \\
\hline 114 & 280656082305801 & Section21 1 & 570.0 & 70.0 & UFA & WL \\
\hline 115 & 280654082305803 & Section $213 \mathrm{~d}$ & 411.0 & 71.0 & SA & WL \\
\hline 116 & 280654082305802 & Section $213 \mathrm{a}$ & 12.5 & 10.5 & SA & WL \\
\hline 117 & 280738082303301 & Section $215 b$ & 22.0 & -- & SA & WL \\
\hline 118 & 280728082301102 & Section $217 \mathrm{~d}$ & 1250.0 & 718.0 & UFA & WL \\
\hline 119 & 280728082301103 & Section $217 \mathrm{i}$ & 728.0 & 145.0 & UFA & WL \\
\hline 120 & 280728082301104 & Section $217 \mathrm{~s}$ & 14.8 & -- & SA & WL \\
\hline 121 & 280732082305801 & Section21 26d & 300.0 & 141.0 & UFA & WL \\
\hline 122 & 280732082305802 & Section21 26s & 13.1 & -- & SA & WL \\
\hline 123 & 280648082302601 & Section 21433 Deep & 49.0 & 47.0 & UFA & WL \\
\hline 124 & 280648082302602 & Section 21433 Shallow & 19.0 & 17.0 & SA & WL \\
\hline 125 & 280729082300501 & Section 21455 Shallow & 9.5 & 7.0 & SA & WL \\
\hline 126 & 280726082305301 & Section $21455 \mathrm{~S}$ alternate & 9.0 & -- & SA & WL \\
\hline 127 & 280650082301401 & Section 21466 Deep & 49.0 & -- & UFA & WL \\
\hline 128 & 280650082301402 & Section 21466 Shallow & 30.0 & -- & SA & WL \\
\hline 129 & 280740082301201 & Section 21468 Deep & 69.0 & 65.0 & UFA & WL \\
\hline 130 & 280702082302801 & Hillsborough 13 Deep & 347.0 & 45.0 & UFA & CWR, QW \\
\hline 131 & 280702082302802 & Hillsborough 13 Shallow & 23.0 & 21.0 & SA & QW, WL \\
\hline 132 & 280544082324706 & HML 32 Lake Shore Nest & 10.0 & 1.0 & SA & WL \\
\hline 133 & 280718082295601 & RL Augmentation (new) & 530 & 140 & UFA & FM, QW, WL \\
\hline
\end{tabular}


Appendix B. Median water quality for Dosson Lake, Halfmoon Lake, and Round Lake, October 1996 through June 1998

[All units in milligrams per liter unless noted; $\mathrm{CaCO}_{3}$, calcium carbonate; $\mathrm{N}$, nitrogen; $\mathrm{P}$, phosphorus; $\mathrm{PCU}$, platinum cobalt units; $\mu \mathrm{S} / \mathrm{cm}$, microsiemens per centimeter at 25 degrees Celsius; ${ }^{\circ} \mathrm{C}$, degrees Celsius; $\mathrm{pH}$, standard units; <, less than; nutrients and alkalinity (acid neutralizing capacity) are whole water (total); major ions are dissolved; $\mathrm{dpm} / \mathrm{L}$, disintegrations per minute per liter]

\begin{tabular}{|c|c|c|c|}
\hline $\begin{array}{l}\text { Chemical constituents and } \\
\text { field properties }\end{array}$ & Dosson Lake & Halfmoon Lake & Round Lake \\
\hline Calcium & 6.3 & 8.9 & 38 \\
\hline Magnesium & 1.4 & 3.2 & 2.0 \\
\hline Sodium & 8.8 & 18 & 7.7 \\
\hline Potassium & 1.6 & 3.2 & 0.40 \\
\hline Chloride & 14 & 32 & 13 \\
\hline Sulfate & 3.9 & 26 & 1.4 \\
\hline Alkalinity as $\mathrm{CaCO}_{3}$ & 13 & 11 & 96 \\
\hline Total dissolved solids & 46 & 124 & 120 \\
\hline Organic nitrogen as $\mathrm{N}$ & 1.3 & 0.48 & 0.24 \\
\hline Nitrite nitrogen as $\mathrm{N}$ & $<0.01$ & $<0.01$ & $<0.01$ \\
\hline Nitrite-plus-nitrate nitrogen as $\mathrm{N}$ & $<0.02$ & 0.02 & $<0.02$ \\
\hline Nitrogen, ammonia total & 0.02 & 0.03 & 0.01 \\
\hline Phosphorus, total as $\mathrm{P}$ & 0.04 & $<0.02$ & $<0.02$ \\
\hline Phosphorus, ortho as $\mathrm{P}\left(\mathrm{PO}_{4}\right)$ & 0.01 & $<0.01$ & $<0.01$ \\
\hline Color (PCU) & 105 & 10 & 10 \\
\hline Temperature $\left({ }^{\circ} \mathrm{C}\right)$ & 23 & 25 & 25 \\
\hline Specific conductance $(\mu \mathrm{S} / \mathrm{cm})$ & 99 & 209 & 240 \\
\hline $\mathrm{pH}$ & 6.2 & 6.2 & 7.7 \\
\hline Dissolved oxygen & 5.1 & 5.9 & 7.5 \\
\hline Secchi depth (in feet) ${ }^{1}$ & 2.8 & 7.9 & 9.8 \\
\hline Radium-226 (dpm/L) ${ }^{2}$ & & & 3.5 \\
\hline
\end{tabular}

${ }^{1}$ Southwest Florida Water Management District water-quality data.

${ }^{2}$ Southwest Florida Water Management District water-quality data, collected on February 1, 1999. 
Appendix C. Range and median water quality for the surficial aquifer for each lake basin, October 1996 through June 1998

[All units in milligrams per liter unless noted; $\mathrm{CaCO}_{3}$, calcium carbonate; $\mathrm{N}$, nitrogen; $\mathrm{P}$, phosphorus; $\mu \mathrm{S} / \mathrm{cm}$, microsiemens per centimeter at 25 degrees Celsius; ${ }^{\circ} \mathrm{C}$, degrees Celsius; $\mathrm{pH}$, standard units; <, less than; nutrients and alkalinity (acid neutralizing capacity) are whole water (total); major ions are dissolved]

\begin{tabular}{|c|c|c|c|c|c|c|}
\hline \multirow[t]{2}{*}{$\begin{array}{c}\text { Chemical constituents and field } \\
\text { properties }\end{array}$} & \multicolumn{2}{|c|}{$\begin{array}{l}\text {-Dosson Lake-_ } \\
7 \text { surficial aquifer } \\
\text { wells }\end{array}$} & \multicolumn{2}{|c|}{$\begin{array}{c}\text {-Halfmoon Lake- } \\
13 \text { surficial aquifer } \\
\text { wells }\end{array}$} & \multicolumn{2}{|c|}{$\begin{array}{l}\text {-Round Lake- } \\
12 \text { surficial aquifer } \\
\text { wells }\end{array}$} \\
\hline & Range & Median & Range & Median & Range & Median \\
\hline Calcium & $0.8-9.8$ & 4.8 & $0.7-63$ & 23 & $2.5-140$ & 30 \\
\hline Magnesium & $0.36-2.1$ & 1.1 & $0.1-11$ & 1.4 & $0.4-15$ & 2.0 \\
\hline Sodium & $4.5-17$ & 7.9 & $0.1-27$ & 4.8 & $1.5-73$ & 13 \\
\hline Potassium & $0.1-1.2$ & 0.4 & $0.2-24$ & 1.7 & $<0.10-4.7$ & 0.30 \\
\hline Chloride & $9.2-32$ & 13 & $1.2-63$ & 14 & $2-160$ & 19 \\
\hline Sulfate & $0.7-13$ & 3.8 & $3.8-57$ & 19 & $<0.2-190$ & 10 \\
\hline Alkalinity as $\mathrm{CaCO}_{3}$ & $<1.0-17$ & 4.6 & $<1.0-165$ & 16 & $1.5-157$ & 69 \\
\hline Total dissolved solids & $26-138$ & 90 & $66-240$ & 157 & $44-794$ & 162 \\
\hline Nitrate-plus-nitrite nitrogen as $\mathrm{N}$ & $<0.02-0.14$ & 0.02 & $<0.20-9.6$ & 0.10 & $<0.02-1.9$ & 0.01 \\
\hline Nitrogen, ammonia total & $0.02-0.61$ & 0.14 & $<0.01-1.8$ & 0.05 & $0.01-1.0$ & 0.10 \\
\hline Phosphorus, ortho as $\mathrm{P}$ & $<0.01-1.5$ & 0.04 & $<0.01-0.28$ & 0.01 & $<0.01-1.2$ & 0.08 \\
\hline Temperature $\left({ }^{\circ} \mathrm{C}\right)$ & $20-27$ & 24 & $20-30$ & 24 & $22-27$ & 24 \\
\hline Specific conductance $(\mu \mathrm{S} / \mathrm{cm})$ & $58-135$ & 80 & $92-370$ & 271 & $72-1,170$ & 263 \\
\hline $\mathrm{pH}$ & $4.2-5.9$ & 5.0 & $4.1-7.4$ & 5.4 & $4.0-6.8$ & 5.8 \\
\hline Dissolved oxygen & $0.56-6.5$ & 1.4 & $0.5-5.3$ & 1.1 & $0.22-4.7$ & 1.6 \\
\hline
\end{tabular}


Appendix D. Water quality for the intermediate confining unit and Upper Floridan aquifer for each lake basin, October 1996 through June 1998

[All units in milligrams per liter unless noted; $\mathrm{CaCO}_{3}$, calcium carbonate; $\mathrm{N}$, nitrogen; $\mathrm{P}$, phosphorus; $\mu \mathrm{S} / \mathrm{cm}$, microsiemens per centimeter at 25 degrees Celsius; ${ }^{\circ} \mathrm{C}$, degrees Celsius; $\mathrm{pH}$, standard units; <, less than; --, not determined; nutrients and alkalinity (acid neutralizing capacity) are whole water (total); major ions are dissolved; dpm/L, disintegrations per minute per liter]

\begin{tabular}{|c|c|c|c|c|c|c|}
\hline \multirow{2}{*}{$\begin{array}{l}\text { Chemical constituent } \\
\text { and field properties }\end{array}$} & \multicolumn{3}{|c|}{ Intermediate confining unit } & \multicolumn{3}{|c|}{ Upper Floridan aquifer } \\
\hline & $\begin{array}{l}\text { Dosson } \\
\text { Lake }\end{array}$ & $\begin{array}{l}\text { Halfmoon } \\
\text { Lake }\end{array}$ & $\begin{array}{l}\text { Round } \\
\text { Lake }\end{array}$ & $\begin{array}{l}\text { Dosson } \\
\text { Lake }\end{array}$ & $\begin{array}{l}\text { Halfmoon } \\
\text { Lake }\end{array}$ & $\begin{array}{l}\text { Round } \\
\text { Lake }\end{array}$ \\
\hline Calcium & 6.5 & 38 & 73 & 18 & 37 & 84 \\
\hline Magnesium & 0.5 & 1.6 & 3.1 & 0.7 & 1.4 & 2.2 \\
\hline Sodium & 8.0 & 5.6 & 7.9 & 9.3 & 7.6 & 12 \\
\hline Potassium & 0.6 & 0.3 & 1.9 & 7.0 & 2.6 & 0.7 \\
\hline Chloride & 7.6 & 13 & 14 & 7.1 & 11 & 22 \\
\hline Sulfate & 5.7 & 22 & 1.2 & 14 & 14 & 0.5 \\
\hline Alkalinity as $\mathrm{CaCO}_{3}$ & 22 & 75 & 199 & 53 & 129 & 219 \\
\hline Total dissolved solids & 57 & 144 & 264 & 107 & 167 & 266 \\
\hline Nitrate-plus-nitrite nitrogen as $\mathrm{N}$ & 0.05 & $<0.02$ & $<0.02$ & 0.05 & $<0.02$ & $<0.02$ \\
\hline Nitrogen, ammonia total & 0.30 & 0.07 & 0.45 & 0.08 & 0.12 & 0.66 \\
\hline Phosphorus, ortho as $\mathrm{P}$ & -- & 0.03 & 0.02 & $<0.01$ & 0.04 & 0.02 \\
\hline Temperature $\left({ }^{\circ} \mathrm{C}\right)$ & 23 & 24 & 22 & 24 & 24 & 23 \\
\hline Specific conductance $(\mu \mathrm{S} / \mathrm{cm})$ & 81 & 254 & 423 & 162 & 318 & 499 \\
\hline $\mathrm{pH}$ & 6.2 & 6.8 & 7.4 & 9.3 & 8.2 & 6.9 \\
\hline Dissolved oxygen & 3.4 & 1.0 & 2.6 & 3.4 & 0.6 & -- \\
\hline Radium-226 (dpm/L) & & & & & & $1_{5.8}$ \\
\hline
\end{tabular}

${ }^{1}$ Radium-226 sample collected January 22, 1999.

Appendix E. Isotopic data for rainfall samples at Section 21 well field [ठD, deuterium; $\delta^{18} \mathrm{O}$, oxygen-18]

\begin{tabular}{|c|c|c|c|c|}
\hline \multicolumn{2}{|c|}{ Sample period } & \multicolumn{2}{|c|}{ Section 21 rainfall } & \multirow{2}{*}{$\begin{array}{c}\text { Sample period } \\
\text { rainfall } \\
\text { (in inches) }\end{array}$} \\
\hline Begin date & End date & $\begin{array}{c}\delta D \\
\text { (per mil) }\end{array}$ & $\begin{array}{c}\delta^{180} \mathrm{O} \\
\text { (per mil) }\end{array}$ & \\
\hline $10 / 08 / 97$ & $11 / 07 / 97$ & -28.7 & -5.15 & 7.9 \\
\hline $11 / 07 / 97$ & 11/14/97 & -16.9 & -3.75 & 3.0 \\
\hline $11 / 14 / 97$ & $12 / 17 / 97$ & -18.6 & -3.83 & 10.8 \\
\hline $12 / 17 / 97$ & 01/05/98 & -10.8 & -2.87 & 7.2 \\
\hline $01 / 05 / 98$ & $02 / 02 / 98$ & -5.2 & -2.34 & 6.9 \\
\hline $02 / 02 / 98$ & 03/04/98 & -4.6 & -1.92 & 12.2 \\
\hline 03/04/98 & $04 / 06 / 98$ & -11.9 & -3.00 & 6.9 \\
\hline 04/06/98 & 05/05/98 & 1.2 & -0.54 & 0.3 \\
\hline 05/05/98 & 06/03/98 & -17.0 & -3.09 & 1.4 \\
\hline $06 / 08 / 98$ & 07/13/99 & -20.1 & -4.01 & 9.5 \\
\hline 08/03/98 & 09/01/98 & -12.6 & -2.91 & 7.2 \\
\hline \multirow[t]{2}{*}{ 09/01/98 } & $10 / 09 / 98$ & -26.2 & -4.07 & 16.4 \\
\hline & & $1_{-16.3}$ & $1_{-3.40}$ & ${ }^{2} 89.8$ \\
\hline
\end{tabular}

${ }^{1}$ Volume weighted mean.

${ }^{2}$ Total rainfall. 
Appendix F. Isotopic data for water from the surficial aquifer, intermediate confining unit, and Upper Floridan aquifer for Dosson Lake, Halfmoon Lake, and Round Lake

$\left[\delta \mathrm{D}\right.$, deuterium; $\delta^{18} \mathrm{O}$, oxygen-18; RL aug, Round Lake augmentation well; DL, Dosson Lake; HML, Halfmoon Lake; RL, Round Lake; (90), refers to index number in appendix A]

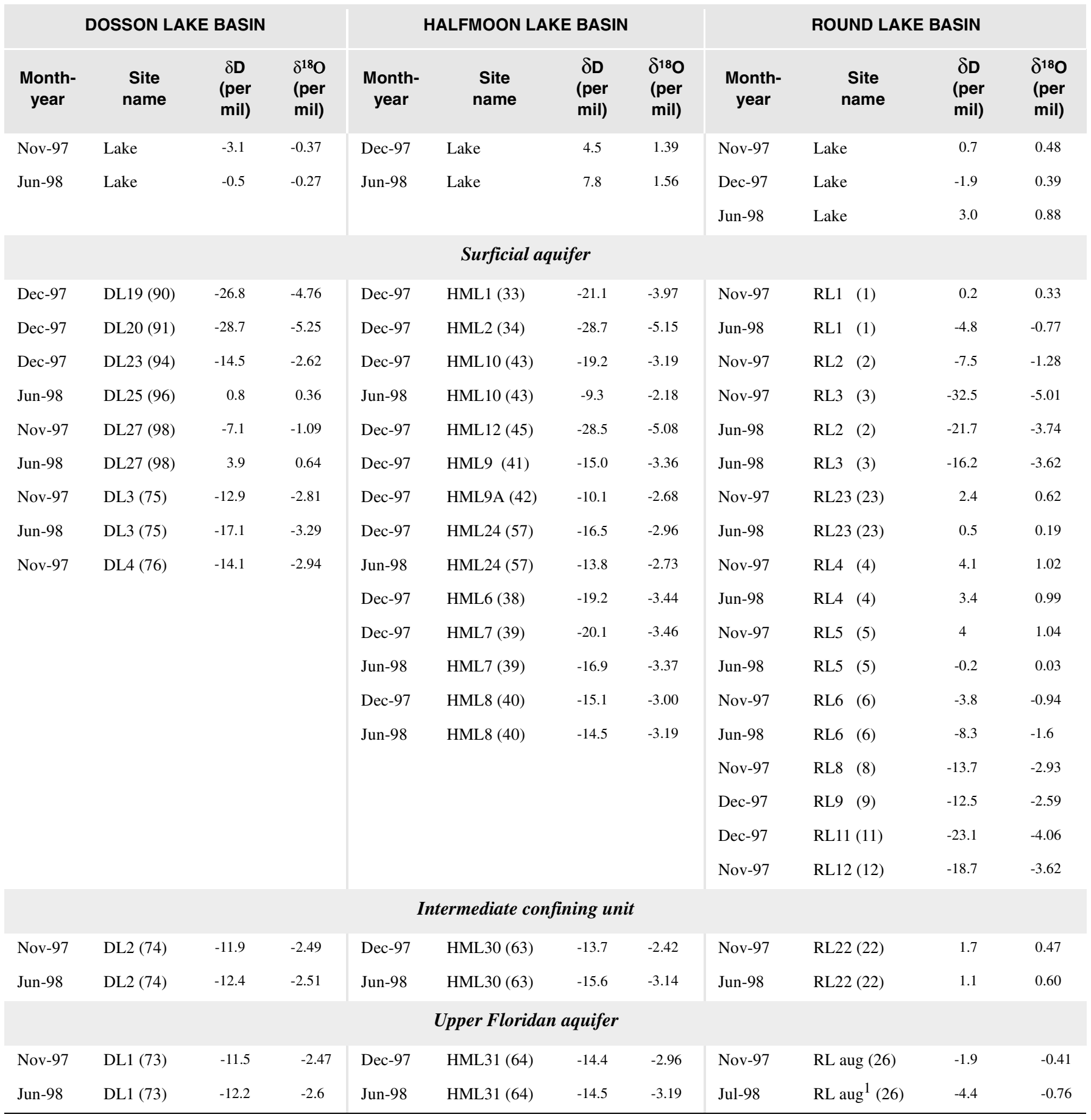

\footnotetext{
${ }^{1}$ The original augmentation well collapsed in June 1998 and a nearby well (approximately 500 feet to the northeast with similar construction) was
} sampled as a replacement well. 